\title{
CINÉTICA DA ABSORÇÃO DE FÓSFORO E ESTADO NUTRICIONAL DO FEIJOEIRO SOB INFLUENCIA DE MICORRIZA VESICULO-ARBUSCULAR
}

ADRIANA PARADA DIAS DA SILVEIRA

Orientadora: Dra. Elke J.B.N. Cardoso

Teso Apresentads à Escols Superior do Agricultura "Luiz de Queiroz", da Univor. sidado do São Peulo, para Obtençāo do

Título de Doutor em Agronomla, área do

Concentrą̧ão: Solos o Nutriçāo do Plentes.

PIRACICABA

Estado de São Prulo - Bresil

Novembro - 1990 
Ficha catalográfica preparada pela Seção de Livros da Divisão de Biblioteca e Documentação - PCAP/USP

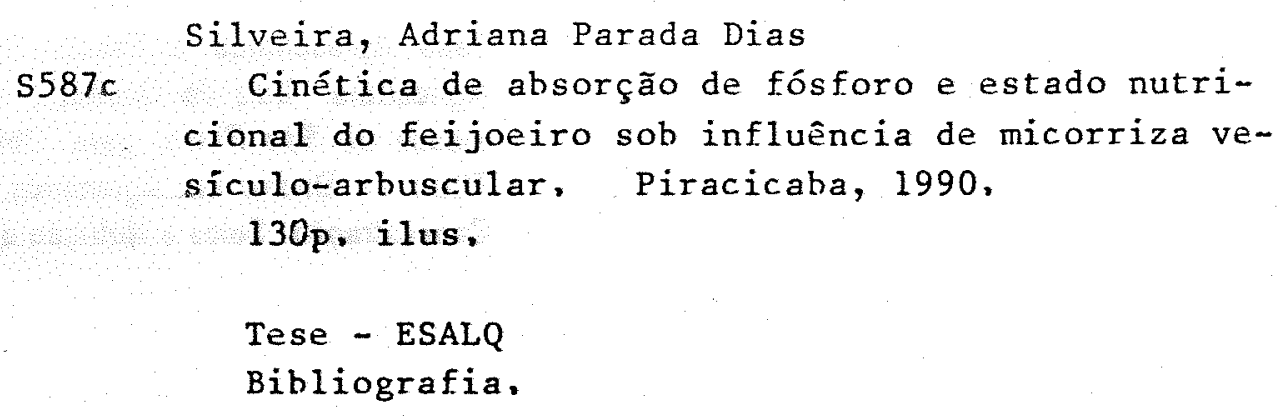
cional do feijoeiro sob influência de micorriza vesiculo-arbuscular, Piracicaba, 1990,

1. Feijão - Micorriza 2, Feijão - Nutrição 3, Fósforo em feijão - Absorção 4. Micorriza I. Escola Su perior de Agricultura Luiz de Queiroz, Piracicaba, 
CINÉTICA DA ABSORÇÁO DE FÓSFORO E ESTADO NUTRICIONAL DO FEIJOEIRO SOB INFLUÊNCIA DE MICORRIZA VESÍCULO-ARBUSCULAR

Aprovada em: $13 \cdot 12 \cdot 1990$

Comissão Julgadora:

Profa. Dra. Elke J.B. Nogueira Cardoso

ESALQ/USP

Dra. Angela Maria Cangiani Furlani

IAC

Dr. Eli Sidney Lopes

IAC

Prof. Dr. Toshiashi Kinjo

ESALQ/USP

Prof. Dr. Takashi Muraoka

CENA/USP

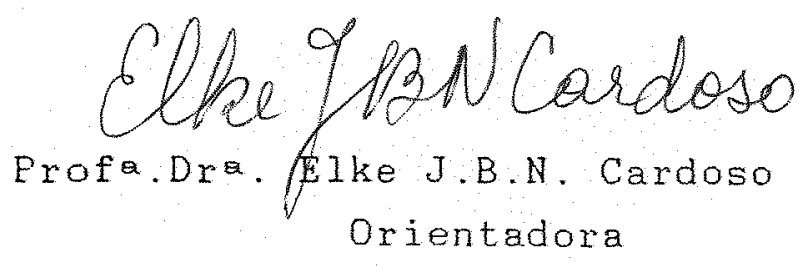


Aos meus avós,

Olga e Agostinho,

pelo exemplo de vida,

OFERESO.

Aos meus pais

e ao meu marido,

DEDICO . 


\section{AGRADECIMENTOS}

A Profa. Elke Cardoso pela orientacão, estímulo e amizade que têm sido demonstrados nesses dez anos de convivencia.

Ao Departamento de Solos, Geologia e Fertilizantes da ESALQ, pela oportunidade de trabalho e pelos servicos prestados.

A FAPESP pela concessão de Bolsa de doutorado e subvencionamento do projeto de pesquisa realizado.

Ao Instituto de Botânica e Instituto Agronômico pelas Ferilidades concedidas para finalizaça deste trabalho.

Aos colegas da pós-graduação pela amizade, colaboração e sugestões, e em especial ao colega Valdemar Faquim, pela orientação e auxílio nos ensaios de cinética, e Edgar Moreira Brandão e Rosângela Navarro pelo companheirismo demonstrado.

Aos laboratoristas, Waldemir Martinelli, Denise L.C. Nescolotti e Fernando Baldesin, pelos auxilios prestados.

Ao Prof Virgilio Nascimento Fo, da Seção de Radioisótopos do CENA, pelo auxilio no manuseio do material radioativo.

Ao Wanderley, meu marido, pela compreensäo, estámulo e ajuda prestada.

A lodus arueles que de algma forma contribuiram para realização deste trabalho. 


\section{SUMÁRIO}

RESUMO . . . . . . . . . . . . . . . . . . .

SUMMARY $\ldots \ldots \ldots \ldots \ldots \ldots \ldots \ldots \ldots \ldots \ldots \ldots$ vi $\ldots \ldots \ldots \ldots \ldots$

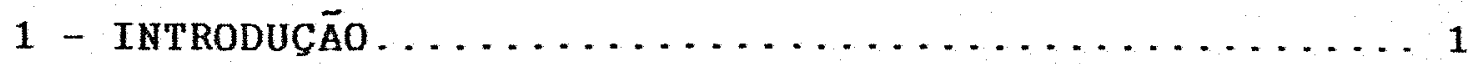

2 - REVISÃo dA LITERATURA $\ldots \ldots \ldots \ldots \ldots \ldots \ldots \ldots \ldots$

2.1 - Fisiologia da absorca de nutrientes em Micorriza vesiculo-arbuscular...........4

2.2 - Cinética da Absorção de Fosfato......... 14

3 - Matertal E MÉtodos... . . . . . . . . . . . . . . . . . 24

3.1 - Crescimento e Nutriça Mineral........... 24

3.1 .1 - Descriça dos Experimentos.........24

EXPERIMENTO I . . . . . . . . . . . . . . 24

EXPERIHENTO II . . . . . . . . . . . . . . . . . 24

EXPERIMENTO III . . . . . . . . . . . . . . 25

3.1 .2 - Material e Procedimentos Gerais.....2 25

3.1.3.- Avaliaça estatística.......... 29

3.2 - Cinética da Absorção do Fosfato.......... 29

4 - RESUltados.......................... 32

4.1 - EXPERIMENTO I. . . . . . . . . . . . . 32

4.2 - EXPERIMENTO II . . . . . . . . . . . . 43

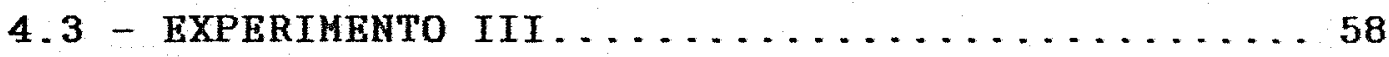

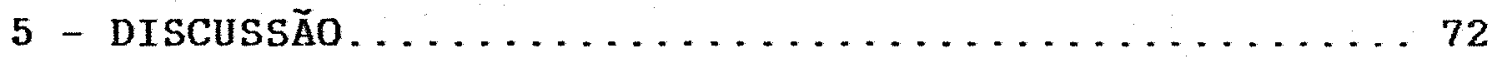

5.1 - Cinética da Absorção de Fosfato...........72

5.2 - Crescimento e Nutricão Mineral.......... 83

6 - conclusões. . . . . . . . . . . . . . . . . . . 98

7 - LitERATURA CITADA. . . . . . . . . . . . . . . . . . 99

8 - APÊNDICE . . . . . . . . . . . . . . . . . . . 125 


\section{Cinética da Absorcão de Fósforo e Estado Nutricional do Feijoeiro sob Influência de Micorriza Vesiculo-arbuscular}

Autora: Adriana P.D. Silveira.

Orientadora: Elke J.B.M. Cardoso

\section{Resumo}

Com o objetivo de estudar o efeito da meorrizacão do feijoeiro nos parâmetros cinéticos da absorção radicular de $\mathrm{P}$ ( $\left.\mathrm{V}_{\mathrm{max}}, \mathrm{K}_{\mathrm{m}}, \mathrm{C}_{\mathrm{m}} \mathrm{n}\right)$, no influxo de $\mathrm{P}$, no crescimento e nutrição mineral do feijoeiro conduziram-se três experimentos, em casa de vegetaça e em laboratório. Foi empregado como substrato areia lavada e silica moída, Irigado com solução nutritiva, sendo que todas as plantas foram inoculadas com uma suspensão de cultura de Rhizobium leguminosarum biovar phaseoli. No primeiro experimento, em esquema fatorial 2 X3, empregou-se a cultivar IAC-Carioca, e compararam-se dois níveis de $\mathrm{P}(0,3$ e $3,0 \mathrm{ppm})$, dois fungos micorrizicos vesiculo-arbusculares, Glomus etunicatum e Scutellospora heterogama e uma testemunha (ausência de fungo micorrizico). No segundo, conduzido em esquema fatorial $2 \times 4$, empregaram-se duas cultivares, IAC-Carioca e Negro Argel, dois fungos, Glomus etunicatum e Scutellospora heterogama, e duas testemunhas com diferentes niveis de $\mathrm{P}$ adicionado: $\mathrm{P}_{1-}$ 0,3 e $\mathrm{Pz}-3,0$ ppm $\mathrm{P}$. No terceiro experimento, foram avaliados dois estádios do ciclo da planta: inicio do florescimento (35 dias após semeadura, DAS) e enchimento das vagens (50 DAS), empregando-se a cultivar IAC-Carioca, colonizada pelo fungo Glowus etunicatum.

Por ocasia da colheita, procedeu-se ao 
ensaio de cinética de absorção de P. Empregaram-se plantas inteiras e foi realizado pelo método de esgotamento do $32 \mathrm{P}$ da solucão nutritiva em funça do tempo de absorção (curva de depleção), por um periodo de 12 horas.

Os resultados permitiram observar que:

- A micorrizaça do feijoeiro influenciou os parâmetros cinéticos da absorção radicular de $P$.

- As plantas micorrizadas, no menor nivel de $P(0,3$ ppm) apresentaram maior $\mathrm{V}_{\max } \mathrm{e}$ influxo líquido e menor $\mathrm{K}_{\mathrm{m}} \mathrm{e}$ $\mathrm{C}_{m i n}$ do que as não micorrizadas, ocorrendo uma inversão nestes resultados com o aumento no nivel de $P(3,0 \mathrm{ppm})$, urincipalmente nas plantas em simbiose com $G$. etunicatum.

- As plantas colonizadas por G. etunicatun, em ambas as doses de $P$, as colonizadas por $S$. heterogama na maior dose de $P$ apresentaram maior eficiência simbiótica e maiores indices de eficiência na utilizaça dos nutrientes.

- Houve relação entre o micotrofismo e os parâmetros ciméticos de absorção de $P$, sugerindo que a cinética de apsorgão pode ser empregada como critério de seleção de fungos eficientes.

- Maior influxo e $V_{m a x}$, menor $K_{m}$ e $C_{m i n}$, além de maior crescimento e melhor estado nutricional foram observados nas plantas colonizadas por G. etunicatum, em ambas as cultivares.

- Nos dois estádios de desenvolvimento do feijoeiro, a micorrização causou aumentou na $V_{\max }$ e diminuiu $K_{m}$, além de aumentar o influxo e influxo líquido por planta.

- O estabelecimento da micorriza pode causar alteracão no estado nutricional da planta e nas relações entre os nutrientes, aumentado a eficiência de utilização dos nutrientes pela planta, em condicoóes de - baixa disponibilidade de $P$. 


\title{
Kinetics of Phosphorus Uptake and Nutrient Status of Common Bean under Influence of Vesicular -Arbuscular Mycorrhiza
}

\author{
Author: Adriana P.D. Silveira \\ Adviser: Elke J.B.N. Cardoso
}

\section{Summary}

The effect of mycorrhiza on the kinetics parameters of $32 \mathrm{P}$ uptake $\left(V_{m a x}, K_{m}, C_{m i n}\right), P$ influx, growth and nutrient status of common bean plants was evaluated. Three experiments, performed under greenhouse and laboratory conditions, were conducted. All plants were inoculated with Thizobium leguminosarum biovar phaseoli and grown in sand culture. The first experiment, in a factorial design $2 \times 3$, tras conducted with the cultivar IAC-Carioca and consisted of two $\mathrm{P}$ levels, 0.3 and $3.0 \mathrm{ppm}$, two mycorrhizal fungi, Glomus etunicatum and Scutellospora heterogama, and a control (without mycorrhizal fungi). The second experiment had a factorial design $2 \times 4$ and the treatments consisted of two bean cultivars, IAC Carioca and Negro Argel, two mycorrhizal fungi, G. etunicatum and $S$. heterogama, and controls fertilized with two $P$ levels, $P_{1}-0.3 \mathrm{ppm}$ and $\mathrm{P}_{2}-$ $3.0 \mathrm{ppm}$. In the third one, plants of cultivar IAC-Carioca colonized with $G$. etunicatum were harvested at two stages of plant cicle, 35 and 50 days after sowing.

azp uptake was determined by measuring its depletion from nutrient solution, using intact plants,

From the results of the experiments, the following conclusions were drawn:

- The establishment of the mycorrhiza on bean plants affected the kinetics parameters of $P$ uptake and $P$ influx. 
- Plants colonized with G. etunicatum, grown in the lower $P$ level, presented higher $V_{\max }$ and Net influx, and lower $\mathrm{K}_{\mathrm{m}}$ and $\mathrm{C}_{\mathrm{m}} \mathrm{n}$. Increasing the $\mathrm{P}$ level to the substrate, $V_{\max }$ decreased and $\mathrm{K}_{\mathrm{m}}$ and $\mathrm{C}_{\mathrm{m} 1 \mathrm{n}}$ increased.

- There was correlation between mycotrofism and the kinetics parameters of $P$ uptake, suggesting that it may be used as a criterion to select efficient fungi.

- The G. etunicatum - bean symbiosis, both cultivars, exhibited high $\operatorname{Vmax}$ and $P$ influx, low $\mathrm{C}_{\mathrm{m} m \mathrm{n}}$ and high root affinity for $P$ (low $\mathrm{K}_{\mathrm{m}}$ ).

- The mycorrhiza improved plant growth and nutrient uptake only after 50 days from sowing, but mycorrhizal plants presented high $V_{\max }$ and low $\mathrm{K}_{\mathrm{m}}$ at both plant stages.

- The establishment of mycorrhiza on bean plants altered the plant nutrient status, the relations between nutrients in the shoot and the efficiency of nutrient utilization. 


\section{1- INTRODUÇ̃̃o}

A absorção de nutrientes do solo pelas raízes depende do movimento de ions no solo e da capacidade absortiva da raiz. Esta, por sua vez, é função da morfologia e fisiologia do sistema radicular que são diretamente influenciados pelos microrganismos da rizosfera, que podem estar tanto em contato superficial como dentro dos tecidos (BAREA e AZCON-AGUILAR, 1983). A maioria das leguminosas, como o feijoeiro, possui em suas raizes dois tipos de microrganismos simbióticos, bactérias fixadoras do $\mathbb{N}$ atmosférico e fungos micorrizicos, estabelecendo uma associaça tríplice capaz de suprir as plantas principalmente quanto as suas exigências de $N$ e $P$ (MOSSE, 1981; HAYMAN, 1986).

Do ponto de vista nutricional, a grande importância das micorrizas vesículo-arbusculares (MVA) está, justamente, em aumentar a absorgăo de nutrientes como $\mathrm{K}, \mathrm{Ca}$, $\mathrm{Mg}$ e $S$ (ROSS e HARPER, 1970; ROSS, 1971; GRAY e GERDEMANN, 1973; MOJALLALI E WEED, 1978; RHODES e GERDEMANN, 1978; SILVEIRA e CARDOSO, 1987b) e, em especial, os de baixa mobilidade, como $\mathrm{Cu}$ e $\mathrm{Zn}$, com destaque so $\mathrm{P}$ (GILMORE, 1971; LAMBERT et alii, 1979; CARDOSO, 1986; PACOVSKY, 1986; PACOVSKY et alii, 1986a,b; BELL et alii, 1989; LU e MILLER, 1989). Como consequêneia dessa melhora no estado nutricional da planta, vários trabalhos têm demonstrado que a micorrizacão de leguminosas tem fromovido aumentos significativos na nodulaça e fixação do $\mathrm{N}_{2}$ (DAFT e ELGIAHMI, 1974 e 1975; CARLING et alii, 1978; BETHLENFALVAY et alii, 1982a,b,c; PACOVSKY et alii, 1986c; FERREIRA, 1987; PAULA e SIQUEIRA, 1987; VEJSADOVA et alii, 1989), gerando incrementos consideráveis no crescimento da planta e na produça de grãos (ROSS e HARPER, 1970; SILVEIRA e CARDOSO, 1987a; FAQUIM, 1988).

0 efeito benéfico da micorriza é mais 
acentuado em condiçós de baixa disponibilidade de $P$ no solo (MOSSE, 1973; SMITH et alii, 1981; SIQUEIRA e PAULA, 1986), como $f$ o caso da grande maioria dos solos tropicais, caracterizados pela baixa fertilidade e alta acidez, nos quais un acentuado processo de fixaço reduz ainda mais as formas disponiveis de $\mathrm{P}$ as plantas (BIELESKI,1973). Isto evidencia a importância e mesmo a necessidade de haver um manejo adequado da cultura, visando estabelecer uma simbiose eficiente e que, portanto, permita redução na adubaçăo fosfática e, ao mesmo tempo, aumento no aproveitamento do fosfato adicionado (LOPES et alii, 1983).

A despeito da constataca de que as plantas micorrizadas apresentam um maior acumúlo de $\mathrm{P}$ nos tecidos do que as náo micorrizadas, muito pouco se conhece a respeito dos mecanismos envolvidos na absorcăo de $P$ pela micorriza (COOPER, 1984). A hipótese mais aceita é que as hifas externas do microsimbionte agem como uma extensăo do sistema radicular, promovendo uma superficie de absorção de nutrientes mais extensa e melhor distribuida, conferindo-lhe maior capacidade de exploração do solo para além da zona de depleção de $\mathrm{P}$ e maior absorcão de ions (RHODES e GERDEMANN, 1975; TINKER, 1978; OWUSU-BENNOAH e MOSSE, 1979).

Alguns trabalhos envolvendo cinética de absorção radicular de $\mathrm{P}$ têm sido realizados para esclarecer se essa maior absorçăo ocorre em funç̃o de um aumento no número de sitios de absorção promovido pela hifa e/ou maior afinidade da hifa ou da raiz colonizada ao P. Os resultados, no entanto, parecem ser conflitantes: KARUNARATNE et alii (1986) e FAQUIM (1988) obtiveram aumento na absorcão de $\mathrm{P}$ decorrente do maior número de sitios de absorçăo promovido pela hifa (maior $V_{\max }$ ), enquanto CRESS et alii (1979) constataram que, em baixa concentracão de $P$ na solução, a absorcão do elemento pela planta mioorrizada estava associada a um menor valor de $K_{m}$, ou seja, maior afinidade das raizes colonizadas e/ou hifa ao P.

Assim, os objetivos desse trabalho foram 
avaliar o efeito da associaça micorrizica vesiculoarbuscular e de alguns aspectos que interferem no seu estabelecimento e desempenho, tais como o nivel de $P$ no substrato, combinacão hospedeiro-fungo micorrizico e o estádio de desenvolvimento da planta, nos parâmetros cinéticos de absorção radicular de $P$, no crescimento $e$ nutricăo mineral do feijoeiro em simbiose com Rhizobium. 


\section{2 - REVISAO DE LITERATURA}

\section{1 - Fisiologia da absorçăo de nutrientes en Micorriza vesiculo-arbuscular}

Das associaços mutualisticas que se estabelecem nas plantas, as micorrizas vesiculo-arbusculares (MVA) são as mais comuns, pois são encontradas nas riófitas e Pteridófitas bem como nas Gimospermas e Angiospermas, sendo de ocorrência generalizada nos mais diversos habitats (MOSSE, 1981). Să associacões estabelecidas entre alguns fungos filamentosos do solo e raizes de plantas, caracterizadas, basicamente, por três componentes: as raizes do hospedeiro, as hifas do fungo que penetram inter e intracelularmente no córtex da raiz, nas quais pode haver a formaço de estruturas tifioas, denominadas arbusculos e vesiculas, e as hifas externas que se estenden além da rizosfera.

Embora os resultados da interaçăo hospedeirofungo sejam, usualmente medidos em termos de crescimento da planta, a associaça contribui para ambos os simbiontes. Segundo SMITH e GIANINAZZI-PEARSON (1988), dois aspectos contribuem para esse mutualismo: a persistência da fase biotrófica, que é uma consequência da compatibilidade fisiológica e estrutural entre os simbiontes, $\theta$ a habilidade de ambos em favorecer a adequada nutricáo da associacão.

Segundo COOPER (1984), os experimentos de fisiologia envolvendo MVA săo de dificil interpretaço por ainco rafies principais: 1- a falta de conhecimento sobre a fisiologia do fungo micorrízico, em decorrência da impossibilidade de cultivo axênico, faz com que as informacoos a seu respeito sejam obtidas indiretamente. sem considerar as diferenças fisiológicas existentes entre as estruturas externas e internas do fungo; 2 - dificuldade na 
distinça entre a resposta do hospedeiro ao estabelecimento da simbiose e de outros fatores decorrentes de um melhor suprimento de $\mathrm{P} ; 3-$ o ajuste do nivel de $\mathrm{P}$ adicionado ao substrato deve ser tal que permita às plantas năo micorrizadas terem o mesmo tamanho, grau de desenvolvimento e teor de $\mathrm{P}$ que as plantas micorrizadas, possibilitando uma comparacão direta entre elas (PACOVSKY et alii, 1986a); 4en estudos, nos quais o objetivo é detectar as mudanças fisiológicas que ocorrem em funçăo do estabelecimento e desenvolvimento da associaça no deoorrer do ciclo da planta, é necessário que os aspectos da biologia e fisiologia da infeção e colonização das raizes sejam considerados, pois diferem com o hospedeiro e o endófito (SANDERS et alii, 1977); 5- falta de informaço sobre a quantidade de micélio metabolicamente ativo que deve ser alcancada para que a simbiose atinja seu máximo de eficiência.

A maioria dos trabalhos sobre a fisiologia de MVA está relacionada à absorça de $\mathrm{P}$, já que, sem dúvida, o maior beneficio da simbiose está em aumentar o teor deste elemento na planta. TINKER (1975) propôs algumas hipóteses para explicar os mecanismos de aumento na absorça de $P$, devido ao estabelecimento da micorriza. A mais aceita é que - fungo micorríico, por um mecanismo fisico, através do desenvolvimento do micélio externo, é capaz de explorar um maior volume de solo, aumentando, portanto, a superficie de absorçáo das raízes. Considerando-se que: $1-\quad O P$ é um elemento de baixa mobilidade no solo (LEWIS e QUIRK, 1967), necessitando difundir pela soluça do solo até atingir a raiz, 2- que as formas disponiveis de $\mathrm{P}$ no solo ocorrem em concentraçes bastante reduzidas ( RAIJ, 1981) e, que, 3em consequencia desses dois fatores, sua absorção pela planta gere o rápido aparecimento de uma regiá em torno das raízes e pelos radiculares, denominada de zona de depleção de P (CLARKSON, 1985), é fácil compreender que o crescimento das hifas externas, através e além da zona de depleção, 
permite que atuem de forma mais eficiente que as raizea na absorcăo desse nutriente (HAYMAN, 1983).

As hifas externas dos fungos micorrizicos podem atingir comprimentos relativamente grandes, quando comparados ao tamanho de um pelo radicular, alcançando até 7 cm de comprimento (RHODES e GERDEMANN, 1975). De acordo com ABBOTT e ROBSON (1985), em trevo subterrâneo ocorreu uma relaçáo de 250-1400 cm de hifa por on de raiz, sendo que essa razăo depende da especie fúngica.

Mudanças fisiológicas que ocorrem na planta micorrizada também devem estar envolvidas nos mecanismos responsáveis pelo aumento na absorçăo de $\mathrm{P}$. Assim, raizes micorrizadas permanecem ativas por mais tempo (BOWEN et alii, 1975) e ainda possuem maior disponibilidade de energia metabólica para absorver $\mathrm{P}$ contra um gradiente de concentraçáo de $1-10 \mu \mathrm{M}$ de $\mathrm{P}$ no solo para $1-10 \mathrm{mM}$ dentro da raiz (BIELESKI, 1973). Segundo TINKER (1975), o acúmulo de $\mathrm{P}$ no interior da hifa é de $2-4 \mathrm{mM}$.

Onde as taxas de absorção de $P$ do solo por rázes năo micorrizadas são limitadas pela lenta difusão do elemento, as taxas de absorça de raizes mioorrizadas poden ser substancialmente elevadas, permitindo maior crescimento das plantas. Assim, soja nă micorrizada foi mais dependente do teor de $P$ disponivel no solo do que a micorrizada (PACOVSKY e FULLER, 1986). BOLAN et alii (1983) observaram que plantas năo micorrizadas não cresceram abaixo de um certo limiar de concentracăo de $\mathrm{P}$ no golo e mostraram um crescimento sigmóide, enquanto que as micorrizadas tiveram crescimento exponencial. Menor limiar de $P$ no solo foi também constatado para plantas micorrizadas de Centrosema pubescens_e Paspalum notatum (MOSSE et alii, 1973). Resultados semelhantes foram obtidos por FAQUIM (1988) que constatou uma reduça de $62 \%$ na $C_{m} 1 n$ alcançada por plantas de soja micorrizadas, e por SILVEIRA e CARDOSO (1990a) que também abtiveram menor $C_{m i n}$ em soja colonizada por Glomus macrocarpun. Segundo PACOVSKY e FULLER (1986), a planta 
micorrizada é capaz de absorver o P lábil do solo.

Essas alterações fisiológicas, que certamente influenciam a absorcăo ionica pela planta micorrizada, têm conduzido à realizaça de estudos de cinética de absorcão de P, com a finalidade de determinar se o aumento da absorça é devido somente ao aumento da superficie de absorcăo dado pelo fungo (mecanismo fisico) ou devido a uma maior afinidade dos sitios de absorcão do ion (menor $K_{m}$ ) pelo fungo e/ou raiz colonizada, ou uma combinaca de ambos.

$$
\text { CRESS et alii (1979), utilizando raiz }
$$

destacada de tomateiro, observaram que em baixas concentraçoes de $P$ na solucão $(1-20 \mu M)$, as raizes micorrizadas apresentaram menor $\mathrm{K}_{m}$ que as näo mioorrizadas, enquanto que $V_{\max } n a ̈ o$ diferiu. Conoluiram que a maior contribuicăo das mioorrizas no aumento da absoroăo de $P$ foi devido a maior afinidade das raizes ao $\mathrm{H}_{2} \mathrm{PO}_{4}^{-}$. Entretanto, KARUNARATNE et alii (1986), empregando plantas inteiras de soja, constataram que as micorrizadas esgotaram o $\mathrm{P}$ da soluçáo 3 vezes mais rápido e tiveram um efluxo aparente de $P$ menor que as ná micorrizadas. Observaram ainda, que a colonização das raízes não aumentou a afinidade pelo $P$, mas proporcionou maior $V_{m a x}$, ou seja, a maior absorcăo de $P$ foi decorrência do aumento no número de sitios de absorçăo por unidade de área de raiz. FAQUIM (1988) obteve resultados semelhantes também em plantas inteiras de soja; observou que plantas micorrizadas apresentaram maior $K_{m} e$ Vax que não micorrizadas e que as maiores diferenças entre elas ocorreram quando a soja foi cultivada com uma solução nutritiva diluida ( $1 / 5$ da soluçăo completa).

0 emprego de $32 \mathrm{P}$ nos estudos envolvendo MVA já foi realizado por GRAY e GERDEMANN (1969), HATTING et alii (1973), RHODES e GERDEMANN (1975), FERREIRA (1987), FAQUIM (1988), que também constataram um aumento na absorção de $32 \mathrm{p}$ por plantas micorrizadas. A utilização de radioisótopos foi importante para demonstrar que tanto as plantas micorrizadas como as não micorrizadas extraem $P$ do 
mesmo reservatório no solo, ou seja, a micorriza năo se utiliza de formas de. $P$ não disponiveis e parece não solubilizar fosfatos insolúveis (SANDERS e TINRER, 1971; HAYMAN e MOSSE, 1972a,b; POHELL, 1975; GIANINAZZI-PEARSON et alii, 1981; FERREIRA, 1987). O melhor aproveitamento de fosfatos insolúveis por plantas micorrizadas, observado por diversos autores e em várias culturas (MURDOC et alii, 1967; ROSS $\theta$ GILLIAN, 1973; PAIRUNAM et alii, 1980; AZCON-AGUILAR et alii, 1986; CARDOSO, 1985 e 1986) pode ser atribuido ao maior contato físico das hifas com as particulas de fosfato, - que as tornam mais aptas a absorver os ions fosfatos, à medida que estes se dissociam quimicamente (HAYMAN, 1983). Também há que se considerar a presença de microrganismos da rizosfera solubilizadores de fosfatos que, atuando em conjunto com os fungos micorrizicos, promovem maior crescimento e absorção de $P$ pela planta micorrizada ( $A Z C O N$ et alii, 1976; MANJUNATH et alii, 1981). Finalmente, já se observou que a atividade especifica do $32 \mathrm{p}$ nas plantas micorrizadas pode ser menor que nas na micorrizadas, indicando que a micorriza estaria absorvendo $\mathrm{P}$ de outras fontes que năo o 32P-lábil (OWUSU-BENNOAH e WILD, 1980). Isto ocorre devido a dissoluço de fosfatos não lábeis, em decorrência de uma reduçăo na concentracão de $\mathrm{Ca}$ e $\mathrm{P}$ da solucăo, cono consequencia da maior e mais rápida absorcão do $P$ disponivel, pela micorriza.

Recentemente, BOLAN et alii (1987) e JAYACHANDRAN et alii (1989) discutiram a hipótese da produça de sideróforo na micorrizosfera, seja pela própria micorriza, pelo fungo micorrizico ou ainda por algum outro microrganismo do solo. Isso poderia aumentar o $\mathrm{P}$ disponivel em solos de pH baixo, o que seria, entao, um dos mecanismos pelos quais as plantas micorrizadas teriam acesso a fontes de $P$ năo disponiveis às não micorrizadas. Além disso, a micorriza pode interagir com organofosfatos do solo e aumentar a mineralizaçăo destes compostos por hidrólise enzimatica (JAYACHANDRAN et alii, 1990). 
0 influxo de $P$ (taxa de absorçăo por unidade de comprimento ou peso de raiz) do solo para a raiz oolonizada é maior do que o das raizes năo colonizadas, sob as mesmas condicoes ambiente. Segundo SMITH (1990), uma das principais dificuldades na determinaca do influxo e medir a real contribuicăo do fungo no processo de absorgão, e, relacionar tal absorcáo com a porcão da raiz colonizada e do micélio externo que realmente está ativa. SANDERS e TINKER (1973) constataram que nas raizes de cebola micorrizadas, o influxo de $P$ foi $18.10^{-4}$ moles. $\mathrm{cm}^{-1} . \mathrm{s}^{-1}$, ou seja, 6 vezes maior que o obtido nas raizes nao micorrizadas. Em trevo, HALE e SANDERS (1982) comprovaram que o influxo de P ocorre devido a atividade do fungo e SMITH (1982) constataram que o influxo de $P$ nas plantas micorrizadas foi superior ao das nao micorrizadas, em todos os niveis de $P$ adicionado. Em soja, FAQUIM (1988) observou que a micorrizaça promoveu um aumento no influxo líquido de $\mathrm{P}$ por grama de raiz fresea por hora, KARUNARATNE et alii (1986) obtiveram maior influxo liquido por área de raiz e, SILVEIRA e CARDOSO (1990b) observaram um aumento no influxo de $P$, mesmo com adicão de Al ao substrato. JAKOBSEN (1986) constatou, em ervilha, que o influxo de $P$ pela hifa foi de 6.3. 10-4 moles.cm-1 de raiz infectada.

Além do $P$, outros nutrientes, principalmente os de baixa mobilidade no solo, sa mais absorvidos pela planta micorrizada. Maior absorcăo de $\mathrm{Zn}$ por micorrizas estabelecidas em feijzo (MoILVEEN et alii, 1975; KUCEY e JANZEN, 1987), soja (PACOVSKY, 1986), milho, trigo e batata (SWAMINATHAN \& VERMA, 1979; THOMPSON, 1990), frutiferas (GILMORE, 1971; LAMBERT et alii, 1979), amendoim (BELL et alii, 1989) tem sido relatada. $0 \mathrm{~S}$, fornecido em solução nutritiva, também foi mais absorvido por plantas micorrizadas de milho é trevo (GRAY e GERDEMANN, 1973). COOPER e TINKER (1978) demonstraram que o $\mathrm{Zn}$ e o S, assim como o P, săo absorvidos e translocados pela hifa externa, sendo que a proporgăo de fluxo foi de 50:8:1 para $32 \mathrm{p}$, tas e 
${ }^{65} \mathrm{Zn}$, respectivamente. O Ca também pode ser translocado para a planta via hifa, conforme observado por RHODES e GERDEMANN (1978). Maior absorcăo de Cu pela micorriza ja foi constatado em soja (PACOVSKY et alii, 1986a,b; CARDOSO, 1986; FAQUIM, 1988) e frutiferas (TIMMER e LEYDEN, 1978). Com relacáo ao $\mathrm{Mg} \in \mathrm{K}$, a literatura tem mostrado resultados bastante variáveis, conforme revisado por CARDOSO (1986). Outros elementos, como Cs (McGRAW et alii, 1979), brometo e cloreto (BUWALDA et alii, 1983; GRAHAM e SYVERTSEN, 1989), Sr (JACKSON et alii, 1973) foram também mais absorvidos por plantas micorrizadas.

PACOVSKY (1986) observou interações cumplexas intre o $P$ e a absorcăo de micronutrientes, concordando com l.AMBERT et alii (1979) e LAMBAIS (1987). 0 aumento da concentraça de micronutrientes em plantas micorrizadas pode ser devido à retença de nutrientes nos órgãos de armazenamento do fungo. Nesse aspecto, pouco é conhecido sobre os mecanismos de exclusáo seletiva dos elementos por fungos micorrizicos (HAYMAN, 1982), sendo que uma das vantagens adaptativas de tais fungos é a de evitar a toxicidade por metais pesados (HAYMAN, 1983). Isto tem sido observado para Al (MALUF et alii, 1988; MELO et alii, 1987) e Mn (CARDOSO, 1986; LAMBAIS, 1987; PACOVSKY, 1986; PACOVSKY ctalii, 1986a,b; BETHLENEALVAY E FRANSON, 1989; ARINES et alii, 1989), cujos teores foram reduzidos om plantas micorrizadas, sugerindo ser um possivel mecanismo de defesa para a planta.

Recentemente, empregando-se técnicas de diluicao isotopioa (IEN), oongtatou-se que o $N$ tambem é absorvido e translocado pela hifa de fungo micorrizico VA (AMES et alii, 1983 e 1984; SMITH et alii, 1986; BAREA et alii, 1987 ).

Segundo BAREA e AZCON-AGUILAR (1983), há mais de um século se constatou que no sistema radicular de leguminosas se estabelece, com frequência, uma associaço simbiotica tríplice, devido a presença de fungos 
micorrizicos e bactérias fixadoras de $\mathrm{N2}$. Inúmeros sao os trabalhos realizados com a finalidade de demonstrar a relação existente entre o desenvolvimento e a produção de uma leguminosa, o estabelecimento da micorriza e a amento na eficiência da fixaçăo biológica do $\mathrm{Nz}$, como pode ser constatado na revisäo de HAYMAN (1986). Observacóes como aumento no crescimento da planta, no número e peso de nódulos, na taxa de redução de acetileno, na atividade da nitrogenase, no teor de leghemoglobina e conteúdo de proteína nos grăos decorrentes da micorrizacăo foram feitas, entre outros, por DAFT e EL-GIAHMI (1974), SILVEIRA e CARDOSO ( $1987 a, b)$, FERREIRA (1987) em feijao; CARLING et alii (1978), ASIMI et alii (1980), GANRY et alii (1982), HALOS et alii (1982), BETHLENEALVAY et alii (1982a,b,c), CARDOSO (1986), FAQUIH (1988), VEJSADOVA et alii (1989) em soja; DAFT e EL-GIAHMI (1975), BAREA et alii (1980) em Hedicago sativa; DAFT e EL-GIAHMI (1976) em amendoim; BONETTI (1984) em siratro; MANJUNATH et alii (1984) em leucena e por EL-HASSANIN e LIND (1985) em Vicia faba.

A eficiência da fixação do $\mathrm{N}_{2}$ por rizóbio pode ser aumentada pelo estabelecimento de uma associaça micorrízica eficiente. GANRY et alii (1985), utilizando 15N, mostraram que soja nodulada e micorrizada por Glomus mosseae foi capaz de fixar $75 \%$ de $N$ a mais que a soja só nodulada. Em trevo, SCHOENEBERGER et alii (1989a,b) também demonstraram que o $N$ derivado da atmosfera é aumentado na presença da dupla simbiose.

Em leguminosas duplamente infectadas por rizóbio e fungo micorrízico, acredita-se que o aumento na fixaça do $\mathrm{N}$ seja a resultante do fornecimento de $\mathrm{P}$ extra pelo fungo (BETHLENFALVAY e YODER, 1981), pois esse nutriente é limitante ao desenvolvimento da leguminosa (LEME ROCHA, 1971) além de imprescindivel à nodulaçào e ao processo de fixaçăo (DEMETRIo et alii, 1972; FRANCO, 1978). Esse efeito indireto da micorriza tem sido constatado por DAFT e EL-GIAHMI (1974), CARLING et alii (1978), CARDOSO 
(1986), que simularam o efeito do fungo, empregando fosfato solúvel. Aumento na absorção de nutrientes como $\mathrm{Cu}, \mathrm{Zn}, \mathrm{S}$, Mo e outros também favorece a nodulaço e fixacão (PACOVSKY et alii, 1986b; SMITH et alii, 1979), pois sao requeridos pelas plantas em maiores quantidades, quando o processo da fixaça está ativo (LOPES et alii, 1983).

Alguns resultados, entretanto, têm sugerido que a micorrizacăo pode causar efeitos secundários que favoreçam a nodulaça e fixaça do $\mathrm{Nz}$, como também o desenvolvimento da planta. Segundo MOSSE (1973), pode haver alteraçá na permeabilidade da raiz e na producão de exsudatos, afetando o ambiente rizosférico de modo a torná10 mais adequado ao estabelecimento do rizóbio. Resultados $\therefore$ SMITH e DAFT (1977) e SMITH et alii (1979) indicaram que a inoculaça de alfafa e trevo com fungos micorrizicos aumentou a nodulaço e atividade da nitrogenase, não ocorrendo, entretanto, correlacao deste aumento na atividade da enzima com o teor de $P$ no nódulo, indicando que outros nutrientes e/ou mecanismos estejam envolvidos. GODSE et alii (1978), comparando plantas de Vigna unguiculata de mesmo peso e proporção raiz:parte aérea, observaram que as micorrizadas tinham maior conteúdo de $P$ na raiz, nodulaça e atividade da nitrogenase, que as na micorrizadas. Resutados semelhantes foram obtidos por PACOVSKY e FULLER (1986) em soja, empregando plantas adubadas com fosfato como testemunha. Em Lotus pedunculatus, a colonizaço por Gigaspora margarita beneficiou o crescimento da planta, mas esse efeito ná foi devido a maior absorcão de $P$ (SCHOENEBERGER et alii, 1989b).

De acordo com BAREA e AZCON-AGUILAR (1982) esses efeitos nzo nutricionais da MVA poderiam estar envolvidos com a producăo de reguladores de crescimento, como constatado por ALLEN et alii ( 1980 e 1982), que observaram maior produça de citocininas e substâncias semelhantes a giberelinas e ácido abscísico em Bouteloua gracilis micorrizada. Isso, portanto, promoveria mudancas 
fisiológicas e morfológicas no hospedeiro, que favoreceriam tanto o estabelecimento como o desempenho da simbiose.

Outras alteracoóes biogufmicas oriundas da micorrizaca também ja foram constatadas. 0 inoremento no teor ou aparecimento de ácidos graxos, lipideos e fitosteróis específicos de plantas micorrizadas foram relatados por HO (1977), COOPER e LOSEL (1978), NAGY et alii (1980), NORDBY et alii (1981), PACOVSKY e FULLER (1988) e SELVARAJ e SUBRAMANIAN (1990). Além disso, a composição de amino ácidos e proteínas em citros (NEMEC e MEREDITH, 1981), soja (PACOVSKY, 1989), alho e trigo (HEPPER at alii, 1986) micorrizados, é qualitativa e quantitativamente diferente de plantas nå micorrizadas, mas similares no estádio de desenvolvimento e acúmulo de matéria seca.

A micorrizaça ainda pode induzir alterações anatomicas e histoquímicas em folhas devido ao aumento do tecido vascular da planta, as quais acarretariam mudanças na fisiologia da translocaça de água e de nutrientes (KRISHNA et alii, 1981). Vários processos podem estar envolvidos: diminuiço na resistencia ao transporte de água, atribuido pelo melhor estado nutricional da planta micorrizada (SAFIR et alii, 1972); maior eficiência na utilizaço da água absorvida e, portanto, resistencia ao estresse hídrico (SIEVERDING, 1981); maior taxa de transpiracăo e diminuição da resistência das folhas à difusão do vapor de água com aumento na condutividade hidráulica das raízes micorrizadas (ALLEN et alii, 1981; HARDIE a LEYTON, 1981); maior resistência à seca, devido regulação da abertura estomatal (ALLEN e BOOSALIS, 1983).

A micorriza influenciando a rizosfera da planta pode, portanto, alterar significativamente a sua fisiologia, e assim, mudar aspectos de seu desenvolvimento. A ocorrência de alteração no balánço hormonal, variação no estado nutricional, na permeabilidade das membranas e nos constituintes químicos dos tecidos levam a um aumento na taxa fotossintética e na eficiência da alocação de C na 
planta, trazendo como consequência mudancas na sua capacidade de suportar condiçóes ambientes de estresse (LINDERMAN , 1990).

Os estudos da fisiologia da associaçăo, nos mais diversos aspectos, tem, portanto, como objetivo buscar - esclarecimento sobre os mecanismos pelos quais o estabelecimento da simbiose favorece o desenvolvimento e produção da planta, principalmente em condições sub-ótimas de $\mathrm{P}$ disponivel no substrato. Par sua vez, esse conhecimento tem como fim gerar aumentos de produtividade, também pelo manejo adequado da microbiota do solo. No caso das leguminosas, uma maior e mais efetiva interaça entre as bactérias fixadoras do $\mathrm{N}_{2}$ e os fungos micorrizicos poderia significar maior fornecimento de $N$ a planta por $P$ adicionado, resultando, assim, em melhor aproveitamento das adubaçós fosfáticas.

\section{2 - CINÉTICA DA ABSÓRÇ̆O IÔNICA}

A taxa de absorçáo de uma espécie iônica depende da concentraço desse ion na solucão, sendo gue essa relacão não é linear, mas segue uma curva assintótica similar à cinética enzimática descrita por Michaelis-Menten e que supore a existência de um carregador que transporta o ion através da membrana (EPSTEIN e HAGEN, 1952). Assim, a velocidade de absorgăo de um determinado ion sumenta rapidamente com o aumento na concentracăo externa deste ion, quando esta ainda é baixa; à medida que a concentraçăo aumenta os incrementos na velocidade de absorcăo diminuem, chegando a zero nas concentracóes mais altas, daí a denominacão de cinética de saturacão (EPSTEIN, 1975). A hipérbole equilátera que descreve o processo é expressa matematicamente como: $V=y_{m a x} \cdot C-. . V$ representa a $\mathrm{K}_{\mathrm{m}}+\mathrm{C}$ 
1... velocidade, taxa de absorga ou influxo (I) e diz respeito a velocidade de transporte do ion por meio de um carregador, e. depende de dois fatores: capacidade e intensidade. Vmax é a taxa máxima de absorça e representa o fator oapacidade, pois é atingida quando todos os sitios carregadores estão ocupados pelo ion; e o produto da concentracáo total dos sitios carregadores presentes e a velocidade de renovacão dos mesmos carregadores dentro da membrana (EPSTEIN, 1975). 0 $\mathrm{K}_{m}$ a a constante de dissociaça do complexo ioncarregador, representando o fator de intensidade, o qual reflete a fraço dos sitios do carregador que está sendo ocupada pelo ion, en uma determinada concentraca externa deste ion; é denominado constante de Michaelis-Menten, e seu valor corresponde à concentraço do ion na qual se obtem a metade da velocidade máxima de absorçáo. Quanto menor o valor de $\mathrm{K}_{\mathrm{m}}$, ou seja, menor a concentracáo do ín que fornece metade de $V_{\max }$, tanto maior a afinidade dos sitios do carregador pelo ín. De acordo com Fried e Broeshart (1967) citado por JUNGK e BARBER (1975), os valores de $\mathrm{K}_{\mathrm{m}}$ estao entre 1 e $6 \mu M$, quando a concentracão de $P$ na soluça e baixa. A estimativa do $\mathrm{K}_{\mathrm{m}}$ em um experimento de absorcáo iônica depende das condicós ambientes da raiz, incluindo forca iônica da solução (LEE, 1982). C é a conoentração do Ion em solucão, na superficie da raiz.

Quando as raizes estão em solução nutritiva, os lons podem se mover para dentro ou fora da raiz, descrevendo um movimento de influxo - da soluçăo externa para dentro da raiz ou efluxo - de dentro da raiz para a solução externa, sendo que esse movimento é expresso em taxa ou velocidade de influxo (I) ou efluxo (E) por unidade de comprimento, área ou peso de raiz. A diferenca entre o 
influxo e o efluxo fornece o influxo líquido, o gual igualase a zero, quando se alcança uma determinada concentração do ion na solucão, chamada de concentracão mínima, $C_{m}$ n, na qual $I=E$ (CLAASSEN e BARBER, 1974). Assim :

$$
\text { Influxo liquido }=\frac{V_{\max } \cdot C}{K_{m}+C}-E \text {. }
$$

Estes autores consideram que a absorca de nutrientes, como $\mathrm{P}, \mathrm{K}$ e outros, e um mecanismo ativo que opera contra um Eradiente eletroquímico e, portanto o efluxo, que opera na direcao oposta, deve ser passivo e constante, apesar de não ser medido diretamente (ROVIRA, 1869).

Levando em consideraçáo o valor da $\mathrm{C}_{\mathrm{m}} \mathrm{n}$, Barber (1979) citado por MENGEL e KIRKBY (1987) propôs a seguinte equaça para estimativa do influxo liquido:

$$
\text { Influxo liquido }=\frac{V_{\max }\left(C-C_{m i n}\right)}{K_{m}+\left(C-C_{m 1 n}\right)}
$$

A Cmin é geralmente baixa (menor que $5 \mu M$ ) e depende das condicões metabolicas da planta, podendo estar relacionada à desnutricăo da planta em $P$, a qual, em uma condicão de baixa concentração do ion na solução, desenvolveria maior capacidade de absorça de $P$ (JUNGK e BARBER, 1975). Um valor baixo de Cmin caracteriza a capacidade da planta em manter a concentracáo do ion extremamente baixa na zona da raiz (CANAL e MIELNICZUK, 1983). Isso é particularmente importante para plantas de cerrado, onde a disponibilidade de $\mathrm{P}$ é bastante reduzida.

A $V_{\max }$ não é uma constante, e como foi demonstrado por CLAASSEN e BARBER (1976) para o $\mathrm{K}$, depende do teor do elemento na planta, ou seja, quanto maior o teor, menor é o valor de $V_{\max }$. No caso do P, JUNGR e BARBER (1974) demonstraram que o influxo do elemento, bem como sua demanda pela planta foram aumentados com a reducá do sistema radicular. Essas observacóes ressaltan a importancia de se empregar plantas inteiras e não raizes destacadas no estudo da cinética de absorca ionica radioular, ja que o transporte entre parte aérea e raiz coordena a atividade da 
raiz com a demanda da parte áerea, sendo que este controle deve ser hormonal (CLARKSON e HANSON, 1980).

A idade da planta ou o seu estádio de desenvolvimento pode afetar a relaça entre a demanda de $P$ pela planta e o influxo de $P$. WARNCKE e BARBER (1974) mostraram que 0 influxo de $P$ (taxa de absorcão por metro de raiz) em raiz de milho foi maior em plantas novas. JUNGK e BARBER (1975), também em milho, constataram que, enquanto o valor de $\mathrm{K}_{\mathrm{m}}$ foi pouco alterado, $\mathrm{V}_{\mathrm{max}}$ decresceu com idade da planta (atingiu maior valor em plantas com 28 dias), provavelmente, porque a taxa de absorça diminui em raízes velhas (BAR-YOSEF e KAFKAFI, 1971), ou seja, raizes com mais de 7 dias. 0 efluxo de $P$ das raizes, $a C_{m} 1 n$ e influxo líquido também diminuíram com a idade da planta. A razáo para diminuicão do $E$ pode ser devida ao fato de que com o envelhecimento, as raizes passam a perder pouco $P$ ou há uma reduçáa no conteúdo de $\mathrm{P}$ na raiz ou ainda pode haver uma reducão no influxo. Estes autores ainda constataram que uma reuução no sistema radicular não aumentou a absorção por unidade de raiz.

EDWARDS a BARBER (1976) constataram que os parâmetros cinéticos da absorçăo de $\mathrm{P}$ por raiz de soja são influenciados pela idade da planta e pelo desbaste da raiz, de forma diferente do observado por JUNGR e BARBER (1975) em milho, sugerindo que o manejo de aplicaço de fosfato, visando maior eficiência de uso do fertilizante, deve diferir para cada cultura. Assim, os autores observaram que com o envelhecimento houve diminuicăo na $\mathrm{V}_{\max } \mathrm{e}$ influxo líquido e aumento nos valores de $\mathrm{K}_{m}$ e $\mathrm{C}_{\mathrm{m}} \mathrm{n}$, enquanto o $\mathrm{E}$ naio se alterou. Isso significa que as plantas mais velhas foram. menos eficientes em absorver $P$ e năo puderam reduzi-lo na solucão a niveis tão baixos quanto as plantas joveñs -o fizeram, ou seja, maior concentraço de $P$ na soluça seria necessária para que as plantas velhas tivessem a mesma taxa de absorça de $P$ que as mais jovens. O desbaste das raizes aumentou $V_{\max } e O$ influxo líquido nas plantas com até 46 
dias, sendo que a absorçao de $P$ por planta, $K m$ e E não se alteraram. Uma diminuicäo no influxo lfquido, de ate 5 vezes, foi observado por Barber (1974) citado por EDWARDS e BARBER (1976), quando as plantas passaram de 8 para 18 dias. Por outro lado, DREW et alii (1984) não constataram diminuica na $V_{\max }$ em plantas de cevada mais velhas, sendo que em condicós de defiaicnois de $\mathrm{P}$, estas apresentaram maior incremento em $V_{\max }$ do que as plantas mais jovens. Segundo os autores, isso pode indicar que o sistema radicular como um todo mantem seu potencial de transporte de $\mathrm{P}$ a uma taxa elevada, apesar das mudanças anatômicas e fisiológicas que acompanham o envelhecimento.

As plantas que se desenvolvem com um fornecimento mínimo de nutrientes minerais, ou seja, em condiços de deficiencia, posteriormente absorvem mais rapidamente e em maior quantidade os nutrientes, do que as plantas que cresceram sob um fornecimento contínuo e adequado de sais minerais, (Broyer e Hoagland, 1943 citado por LEE, 1982). Segundo EDWARDS e BARBER (1976), possivelmente, as plantas deficientes em $\mathrm{P}$ desenvolvam um mecanismo mais eficiente de absorça do nutriente do que as plantas bem supridas em $P$.

Em cevada, LEE (1982) observou que $V_{\max }$ foi fortemente influenciada pelo nivel de fornecimento do nutriente durante o crescimento da planta, a qual foi duas vezes maior em plantas deficientes em $P$, enguanto o valor de $\mathrm{K}_{\mathrm{m}}$, apesar de menor nas plantas deficientes, mostrou-se menos suscetivel de alteração. Já CARTWRIGHT (1972) constataram que a deficiência de $P$ nå alterou o valor de $V_{\text {max }}$, enquanto que o $K_{m}$ diminuiu três vezes em relaçăo às plantas bem supridas. DREW et alii (1984) observaram que diminuição no fornecimento de $\mathrm{P}$ para plantas de cevada ocasionou um incremento de quatro vezes no $I_{\max }$, sem, entretanto, ocorrer alteracăo no $\mathrm{K}_{m}$, que permaneceu entre 5 e $7 \mu \mathrm{M}$. Em milho, ANGHINONI e BARBER (1980) também observaram aumento de $V_{\max }$ mas $n$ ăo alteraçăo do $\mathrm{K}_{\mathrm{m}}$, em 
plantas deficientes em $P$. Já em tomateiro, ambos, $V_{m a x}$ e $K_{m}$, aumentaram em raízes deficientes em P (Jungk, 1974 citado por DREW et alii, 1984). De acordo com McLACHLAN et alii (1987), tanto en trigo como trevo, as plantas deficientes em $P$ tiveram maiores taxas iniciais de absorcáo e menor $\mathrm{K}_{\mathrm{m}} \mathrm{do}$ que as bem supridas, ocorrendo diferencas significativas entre as cultivares.

DREW e SAKER ( 1984 ) constataram que diferenca na absorcão entre plantas deficientes e bem supridas tambéa ocorre se o sistema radicular da planta for segmentado, ou seja, o segmento do sistema radicular, que recebe um baixo suprimento do ion, apresenta um incremento compensatório na absorçáo deste ion. Segundo Nye Tinker (1978) citado por DREW et alii (1984), tais mudanças, induzidas por estresse, ha habilidade das raizes em absorver ions pode ser de grande importância ecológica, pois modifica, efetivamente, o modo como as raizes aproveitam os nutrientes do solo.

\section{Considerando-se a hipótese do carregador,}

mudanças na $V_{m a x}$ podem indicar alteraçres na concentração de carregadores a nivel de plasmalema, ou seja, aumento ou diminuiça no número de sitios ativos transportadores de um determinado ion, ou, variaço no número de giros do carregador. Isso ocorreria devido a diferença na taxa de sintese e quebra de tais sitios, ocasionando mudancas na capacidade de transporte máximo na raiz. Alteracoes no valor do $\mathrm{K}_{\mathrm{m}}$, havendo ou ná mudancas $\mathrm{na} \mathrm{V}_{\mathrm{mex}}$, podem indicar o desenvolvimento de um outro tipo de sitio de transporte, com uma diferente afinidade pelo ion, envolvendo, portanto, biossintese (LEE, 1982; DREW et alii, 1984), ou regulagao alostérica da afinidade da molécula do carregador já existente, devido a presença, de um modulador na célula (JENSEN e PETTERSON, 1978). Segundo LEE (1982), o controle alostérico envolve somente mudanças conformacionais dos sitios de transporte já existentes, sendo dificil distinguir entre a regulaça alostérica e as mudancas no número e/ou estrutura dos sitios de transporte. 
A natureza do modulador, gue eventualmente controle a absorçăo iônica, é desconhecida, havendo evidências de que formas inorgânicas dos principais nutrientes estejam envolvidas. NASSERY (1971) constatou que a concentraça de $P$ inorganico variou muito mais do que a de $P$ orgânico, quando ocorreram mudanças na concentraçăo externa de P. Ainda, LEFEBVRE e GLASS (1982) observaram que, em cevada deficiente em $P$, a taxa de absorção de $P$ diminuiu com a acúmulo de $P$ inorgânico na célula, o qual, possivelmente, tenha atuado como um modulador alostérico. Entretanto, DREW et alii (1984) nao identificaran nenhuma concentraca eno endogena de $\mathrm{P}$ que pudesse induzir alguma nudança nos parâmetros cinéticos. O mesmo foi constatado por TEW e SAKER (1984), que observaram um grande estimulo na assorcáo e tranporte de $P$ em cevada, após um período de deficiencia deste nutriente, sem entretanto ocorrer mudança concentraçáo do fon dentro da raiz. Esses autores sugerem que, nesse caso, o controle da absorça e transporte do ion nao tenha ocorrido por um processo alostérico regulado pela concentracão interna do fon na raiz, mas sim, por um outro mecanismo. 0 influxo seria, entao, regulado pelo efluxo do ion no xilema, talvez controlado pela concentraça do ion que é reciclado no floema, da parte aérea para a raiz.

$$
\text { Segundo CASTELLS et alii (1985), a }
$$

determinaça dos parâmetros cinéticos de absorção iônica tem sido realizada visando caracterizar a eficiencia diferencial das plantas quanto à absorgáo de nutrientes, facilitar a caracterização de variedades de uma mesma cultura quanto à tolerância ao Al tóxico e, obter informaçóes que permitam a formulaço de modelos que simulem a absorcão de nutrientes, para esclarecimento sobre os mecanismos envolvidos no processo. Portanto, o estudo da cinética de absorção iônica pode ser encarado como um instrumento de trabalho para o melhorista de planta e o fisiologista vegetal.

As plantas, não só a nivel de espécie como também de cultivar, diferem nas caracteristicas de absorça 
de un dado ín, em funçăo da variacão na morfologia da raiz, como também nos mecanismos de absorcăo do ion (BALIGAR e BARBER, 1979; (IIARK, 1933). BALIGAR (1985) OUMPUrou os parfametros cinéticos de absorçáo de $\mathrm{Ca}, \mathrm{Mg}, \mathrm{Na}$ e $\mathrm{P}$ em plantas inteiras de milho e cebola, e constatou que cebola apresentou maior afinidade ao $\mathrm{Ca}, \mathrm{Mg}$ e $\mathrm{Na}$ e maior eficiência na absorça desses nutrientes, enquanto o milho teve maior Imax, menor $K_{m}$ e $C_{m}$ in do que a cebola, em relação ao $\mathrm{P} . \mathrm{Da}$ mesma forma, EDWARDS e BARBER (1976) discutem que comparando-se plantas de mesma idade, o milho apresentou um influxo de $P$ cinco vezes maior que a soja, além da capacidade de absorver $\mathrm{P}$ mais rapidamente, em um curto intervalo de tempo.

Variaçoes nos parâmetros cinéticos de absorça de $P$ já foram observados em diferentes genótipos de milho (NIELSEN e BARBER, 1978; SCHENK e BARBER, 1979; SALIGAR e BARBER, 1979; ANGHINONI et alii, 1989), de trigo e trevo (McLACHLAN et alii, 1987), de soja (VILELA e AIGHINONI; 1984; CASTELLS, 1984) e de arroz (FURLANI, 1988; ANGHINONI et alii, 1989).

\section{Idealmente, uma planta eficiente na}

utilizacão de $P$ seria aquela que tivesse uma alta taxa inicial de absorça de $P$, que fosse mantida pela alta afinidade das raízes ao $\mathrm{P}$, ou seja, apresentasse baixo $\mathrm{K}_{\mathrm{m}} \mathrm{e}$ atingisse uma concentraça mínima baixa, indicando que - a planta foi capaz de extrair o máximo possivel do $\mathrm{P}$ da soluça (NIELSEN e BARBER, 1978; McLACHLAN et alii, 1987). Entretanto, os resultados têm mostrado que há grande dificuldade em se obter uma planta com todas as características desejáveis, en relaçăo à absorção de nutrientes. Alem disso, segundo FuRLANI (1988), o emprego da cinética de absorcáo de nutrientes como parâmetro de selecao de plantas ainda necessita de naiores informacoses quanto à reprodutibilidade dos resultados. Essa autora, trabalhando com diferentes genótipos de arroz, concluiu que os valores de $V_{\max }$ foram os melhores indicadores da 
capacidade diferencial das plantas na absorça de $P$, podendo ser usado como critério de seleçăo; NIELSEN e BARBER (1978) e SCHENK e BARBER (1979) em milho, observaram que os genótipos com maior $V_{\max }$ no ensaio em solucão nutritiva, também foram aqueles que absorveram mais $\mathrm{P}$ em condicóes de campo.

O efeito de tratamentos que possam interferir na morfologia do sistema radicular devem ser levados em consideraça, pois, conforme constatado por CANAL e MIELNICZUK (1983), o efeito negativo do Al, por exemplo, sobre a absorça de $\mathrm{K}$ não alterou diretamente os parâmetros cinéticos, mas inibiu o crescimenta radicular (causou o engrossamento da raiz, aumentando a área de absorção por u idade de comprimento), de tal maneira que houve diferenca no $V_{\max }$, quando expressa por unidade de comprimento de raiz, enquanto que em relação ao volume de raiz, a velocidade de ausorcaao não diferiu para as plantas cultivadas ou não com A1. RUSSELL e SANDERSON (1967) também observaram que a taxa de absorgão de $\mathrm{P}$ foi mais relacionada com o volume radicular do que com área superficial, sugerindo que o peso da matéria fresca pode ser usado para expressá-la. Segundo SCHENK e BARBER (1979), a morfologia da raiz de milho variou com o tipo de solo e influenciou a absorça de $P$, a qual apresentou estreita correlaca com a superficie e o comprimento da raiz. A densidade do solo, tipo de matéria organica, pH e grau de agregaça do solo podem afetar o desenvolvimento do sistema radicular e portanto, alterar o influxo de $P$.

Com base nas características morfológicas e fisiológicas das raizes e nas características de solo, Barber e Cushman, 1981 citados por SILVA e MAGALHAES (1989), desenvolveram um modelo matemático, modelo de Cusham-Barber, que permitindo estimar a absorção de nutrientes $e$ os parâmetros que mais a influenciam, conduzem ao conhecimento das características da planta e do solo mais limitantes e que, portanto, precisam ser modificadas a fim de aumentar a 
absorcăo de nutrientes pela planta. Assim, esses autores observaram que a área superficial da raiz teve grande efeito na absorcáo de $P$ pelo tomateiro, em ambos os solos empregados, sendo que a absorcão estimada pelo modelo e a observada experimentalmente foram bem próximas. Essa mesma observação já tinha sido feita por SCHENK e BARBER (1979), em milho, os quais constataram correlacăo entre a absorça estimada de $P$, pelo modelo de simulacão de Classen e Barber, e a observada empregando-se solo, havendo uma superestimativa de $9 \%$ no primeiro método, porque esse não considera a competica pelo $\mathrm{P}$ entre as rafzes.

O conhecimento sobre as parâmetros cinéticos da absorcáo de ions e dos caracteres morfológicos das raizes, ambos geneticamente controlados, podem ainda fornecer subsidios para programas de melhoramento que visem a obtença de cultivares tolerantes a elementos tóxicos, principalmente $A 1$, cuja presença interfere na absorça de outros ions (VILELA e ANGHINONI, 1984; VALE et alii, $1984 a, b ;$ CANAL e MIELNICZUK, 1983; CASTELLS, 1984; ZHANG e TAYLOR, , 1989). 


\section{3- MATERIAL E METODOS}

0 presente estudo foi desenvolvido no Departamento de Solos, Geologia e Fertilizantes da ESALQ, Piracicaba, e conduzido em casa de vegetaça e no laboratório. Constou de três experimentos, divididos em duas partes: avaliação do crescimento e nutrição mineral das plantas e estudo da cinética da absorção de fosfato.

\section{1- Crescimento e nutrição mineral}

3.1.1- Descrição dos experimentos

EXPERIMENTO I

Teve como objetivo avaliar o efeito da micorriza e do nível de $P$ adicionado, nos parâmetros cinéticos da absorção radicular do $\mathrm{P}$ e desenvolvimento do feijneiro (Phaseolus vulgaris L.), cultivar IAC-Carioca. Arranjado em esquema fatorial $2 \times 3$ e conduzido em delineamento inteiramente casualizado, com dez repetiçóes, empregaram-se dois niveis de $P$ ao substrato $(0.3$ e $3.0 \mathrm{ppm}$ P), dois fungos micorrizicos vesiculo-arbusculares (FMVA), Glomus etunicatun Becker \& Gerdemann e Scutellospora heterofama (Nicol.\& Gerd.) Gerd. \& Trappe e uma testemunha (ausência de FMVA), totalizando seis tratamentos. Foi conduzido no periodo de janeiro a fevereiro de 1987 e avaliado aos 30 dias após semeadura.

\section{EXPERIMENTO II}

- objetivo foi estudar como as simbioses estabelecidas por diferentes fungos e cultivares de feijao influenciam os parâmetros cinéticos da absorção de $P$ e a 
possibilidade de relacionar tais parâmetros com o grau de eficiencia da simbiose, além de avaliar o efeito da micorrizaço no desenvolvimento e nutricăo mineral da planta. Foi conduzido em esquema fatorial $2 \times 4$, em delineamento inteiramente casualizado, com dez repetições, empregando-se duas cultivares, IAC-Carioca e Negro Argel, e dois FMVAs, Glomus etunicatum e Scutellospora heterogama, e duas testemunhas (ausência de FMVA) com diferentes niveis de $\mathrm{P}$ adicionado, 0.3 e $3.0 \mathrm{ppm} \mathrm{P}$, totalizando oito tratamentos. As plantas foram colhidas aos 40 dias após semeadura, sendo que este experimento foi conduzido no período de marco a maio de 1987.

EXPERIMENTO III

Teve como objetivo estudar os parâmetros cinéticos de absorça radicular de $P$ pela micorriza estabelecida em feijoeiro, cultivar IAC-Carioca, bem como seu desenvolvimento e aspectos nutricionais, considerando-se duas épocas do ciclo da planta: inicio do florescimento ( 35 dias após semeadura) e enchimento das vagens ( 50 dias após semeadura). 0 experimento instalado em delineamento inteiramente casualizado com dez repeticos, em esquema fatorial $3 \times 2$, constou do emprego do FMVA Glomus etunicatum e duas testemunhas, uma em que as plantas receberam $0.3 \mathrm{ppm} P$ e outra 3.0 ppm $P$ e da colheita das plantas em duas épocas, totalizando seis tratamentos. Foi conduzido de abril a junho de 1987.

\subsection{2-Material e procedimentos gerais}

No experimento I foi utilizado como substrato areia lavada média - fina, silica moída e solo (Areia Quartzosa da série Paredão Vermelho), na proporção de 8:1:1, com a seguinte análise química: $\mathrm{pH}$ em $\mathrm{CaClz}-5.6$; MO\%-0.28; $\mathrm{P}$ resina $-3.7 \mathrm{ppm} ; \mathrm{K}^{+}-0.03, \mathrm{Ca}^{2+}-0.40, \mathrm{Mg}^{2+}-0.1 \mathrm{e}$ 
$\mathrm{H}^{+}+\mathrm{Al}^{3+}-0.87 \mathrm{meq} / 100 \mathrm{~cm}^{3}$. Nos demais experimentos foi empregado como substrato areia lavada média-fina e silica moida $(\overline{9}: 1)$. A silica foi lavada com água corrente e autoclavada a $121^{\circ} \mathrm{C}$ por 1.5 hora. A areia previamente lavada com água corrente e o solo foram esterilizados com vapor fluente por 2 horas, em 3 dias consecutivos.

Foram utilizados vasos de barro de $3 \mathrm{~kg}$ no experimento $I$ e de plástico de $2.5 \mathrm{~kg}$ nos demais, previamente lavados e desinfestados com lisoforme. Revestiuse o vaso internamente com saco plástico para facilitar a remoço da planta inteira a a transferencia para a solucão nutritiva, sem danificar o sistema radicular. Na parte inferior do vaso foi posta uma camada de $2 \mathrm{~cm}$ de pedra britada, tamanho médio, lavada com água corrente e esterilizada a $121^{\circ} \mathrm{C}$ por 1.5 hora, para facilitar a drenagen da solução.

o inóculo de FMVA, obtido em vasos - estoque com milho, foi espalhado em toda superficie do vaso a $5 \mathrm{~cm}$ de profundidade, e constou de pedacos de raiz infectada, hifas e aproximadamente 2000 esporos. A testemunha recebeu $50 \mathrm{ml}$ de solo do vaso - estoque testemunha, contendo pedacos de raiz de milho mas ausência de propágulos de fungo micorrízico.

As sementes utilizadas, provenientes do banco de germoplasma da Secăo de Leguminosas do IAC, Campinas, SP, foram desinfestadas superficialmente com Hipoclorito de sódio ( $Q$ Boa) $50 \%$ por 5 minutos e lavada com água destilada. Em seguida, as sementes foram submersas em uma suspensáo de células de rizóbio, por 15 minutos, obtida em meio líquido YMB (VINCENT, 1970) com agitação. As estirpes de Rhizobium leguminosarum biovar phaseoli empregadas foram: C-05 II, CIAT 1899 e C-88, fornecidas pelo Laboratório de Microbiologia do solo, do Centro de Energia Nuclear na Agricultura (CENA), Piracicaba. Procedeu-se à semeadura, colocando-se 8 sementes por vaso, sobre as quais foram adicionados $10 \mathrm{ml}$ da suspensăo de rizóbio. O desbaste foi realizado 10 dias após 
semeadura para uma planta por vaso, adicionando-se, novamente, $10 \mathrm{ml}$ da suspensão de rizóbio no colo da planta. Do plantio até o desbaste, os vasos receberam apenas água destilada. A partir dai, foram adicionados, semanalmente, $100 \mathrm{ml}$ da soluço no 2 de HOAGLAND e ARNON (1950) modificada por FAQUIM (1988), conforme consta da Tabela 1, em sistema de drenagem livre, irrigando-se com água destilada quando necessário. Nos tratamentos onde houve inoculaça de fungo micorrizico e em uma das testemunhas, a concentraca de $\mathrm{P}$ utilizada foi 0.3 ppm enquanto na outra testemunha adicionaram-se $3.0 \mathrm{ppm}$. As plantas receberam $N$ parceladamente, sendo $30 \mathrm{ppm}$ por ocasiăo do desbaste e 30 ppm aos 20 dias após semeadura.

Por ocasiao da colheita, cuja época variou conforme o experimento (item 3.1.1), as plantas foram cuidadosamente retiradas dos vasos pelo saco plástico, que uma vez cortado permitiu que o substrato fosse eliminado, mergulhando-se o sistema radicular em sucessivos tanques de água, de modo a minimizar os danos à raiz e evitar, o máximo possivel, o desprendimento de nódulos e de hifa externa do fungo micorrízico. De dez repeticós, quatro foram separadas para o ensaio de cinética (item 3.2 ) e seis para avaliaça o do crescimento e nutriça mineral.

As plantas foram cortadas na altura do colo e a parte aérea posta em saco de papel e levada à estufa com circulaçăo forçada de ar a $65-70 \circ \mathrm{C}$, até peso constante, para obtenção do peso da matéria seca. 
Tabela 1- Concentraçăo dos nutrientes usados na soluça nutritiva de crescimento das plantas e na solucão nutritiva dé absorça de fosfato empregada no ensaio de cinética.

\begin{tabular}{llc}
\hline & SOLUCAOO DE & SOLUÇÕO DE \\
NUTRIENTES & CRESCIMENTO1, & ABSORÇĂO
\end{tabular}

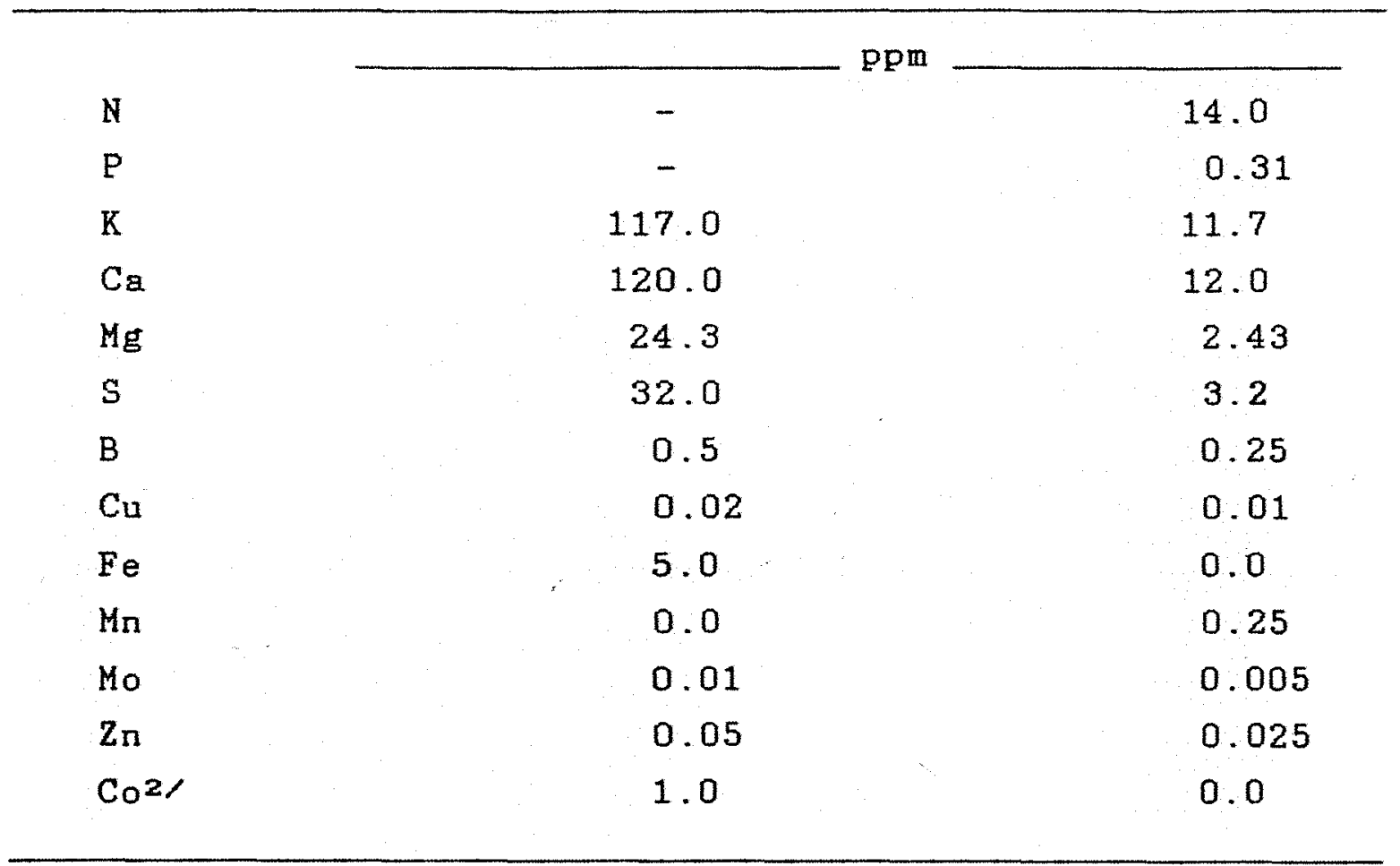

$1 /$ Solução no2 de HOAGLAND e ARNON (1950) modificada para $\mathrm{K}, \mathrm{Ca}, \mathrm{Mg}$ e $\mathrm{S}$, segundo FAQUIM (1988).

2 /Partes por bilhăo (ppb). 
Posteriormente, a matéria seca da parte aérea foi moida em moínho tipo Willey com peneira de 20 malhas por polegada para análise química, segundo SARRUGE e HAAG (1974). ON, após digestăo sulfúrica, foi determinado pelo método de $\mathrm{Kjeldahl;} \mathrm{os} \mathrm{demais} \mathrm{nutrientes,} \mathrm{após} \mathrm{digesta}$ nitro - perclórica, foram assim determinados: $P$ colorimetria; $\mathrm{K}$ - fotometria de chama; $\mathrm{Ca}, \mathrm{Mg}, \mathrm{Cu}, \mathrm{Zn}, \mathrm{Mn}$ e $\mathrm{Fe}$ - espectrofotometria de absorçăo atômica.

0 sistema radicular foi lavado com água corrente e os nódulos foram separados e secos em estufa com circulaca de ar a $65-70 \circ \mathrm{C}$, ate peso constante. A poroentagem do comprimento de raiz infectada for fungo micorrizico foi estimada pelo método de AMBLER e YOUNG (1977), após coloracăo con lacto-glicerol-"trypan blue", segundo PHILLIPS e HAYMAN (1970).

\subsection{3- Avaliaçăo estatística}

Os dados experimentais foram submetidos à análise da variancia, inteiramente casualizado ou fatorial, dependendo do delineamento empregado em cada experimento. A análise estatística foi realizada pelo programa SANEST (Sistema de Análise Estatística) e os dados expressos em porcentagem foram transformados em $Y=$ arcseno da raiz quadrada de $X / 100$. A comparaço de médias foi feita pelo teste de Tukey.

\section{2- Cinética da absorçăo de fosfato}

A caracterização da cinética de absorção radicular de $P$ pelas plantas e determinaça dos parâmetros cinéticos foram realizados pelo método de esgotamento do $P$ da solução em função do tempo de absorção ( curva de depleção), de acordo com a metodologia proposta por CLAASSEN e BARBER (1974), empregando-se plantas inteiras e baixa concentrặăo do elemento na solução. 
Das quatro repeticoes selecionadas para o ensaio de cinética, uma foi empregada em um ensaio prévio, que teve como objetivo estabelecer o volume da solucão $e$ a concentraça de $P$ necessarios para obter um esgotamento do elemento da soluca entre 5 e 8 horas de absorcão.

As plantas retiradas do substrato sólido foram transferidas para soluçăo nutritiva de crescimento correspondente (Tabela 1 ), pH 5.5 (ajustado oom $\mathrm{NaOH}$ ou HCl), em vasos plásticos de 3 litros, com aeração constante, por 3 dias, ainda em casa de vegetacáo.

Quarenta horas antes do inicio do ensaio de cinética, transferiram-se as plantas para a soluça nutritiva de absorcăo (Tabela 1), omitindo-se o $P$, para aumentar a capacidade das raizes em absorver este nutriente (Jungk, 1975 citado por FAQUIM, 1988). Após esse tempo, as plantas foram levadas para o laboratório, onde foi adaptado um sistema de iluminaça mais apropriado, constituido por uma bateria de lâmpadas HPLO de 250 Watts (Phillips) que forneceu uma intensidade luminosa de 35 Hatts/ $\mathrm{m}^{2}$ ao nivel das folhas superiores, e uma temperatura ambiente média variável em cada experimento: I e II $-28^{\circ} \mathrm{C}$ e III- $24^{\circ} \mathrm{C}$.

Transferiram- se as plantas para nova soluçáo de absorça, onde permaneceram por 1.5 hora, com adiça de $10 \mu \mathrm{M}$ de ${ }^{32 P}(0.31 \mathrm{ppm})$ e um volume de 2.5 litros, conforme determinado no ensaio prévio. Esse passo teve como objetivo alcancar o equilíbrio estacionário de absorça do elemento, requerido para a aplicaça do modelo oinetico (EPSTEIN e HAGEN, 1952). Iniciou-se, entáo, o ensaio de cinetica de absorcăo, transferindo-se as plantas para vasos com solucão de absorcão com a concentração de $P$ e volume de solucão previamente determinados, mas marcada com $40 \mu \mathrm{Ci} 32 \mathrm{P} / \mathrm{vaso}$, na forma de $\mathrm{NaH}_{2}{ }^{32 \mathrm{PO}_{4}}$ livre de carregador. A homogeneização dos isótopos foi feita com um bastáo de vidro. o periodo de absorcăo foi de 12 horas, e até a 50 hora as amostragens foram realizadas a cada 0.5 hora, e após, em intervalos de 1.0 hora, totalizando 18 amostragens por vaso. As amostras 
de soluça, aliquotas de $1 \mathrm{ml}$, foram postas em frascos de cintilaçăo com $14 \mathrm{ml}$ de asua desmineralizada e determinou-se a atividade do $32 \mathrm{P}$ pelo efeito Cerenkov (NASCIMENTO Fo e LOBAO, 1977) em um espectrometro beta de cintilacão liquida, no Laboratório de Radioisótopos do Centro de Energia Nuclear na Agricultura (CENA), Piracicaba.

As plantas ficaram sob aeraçăo constante durante toda a duracáo-do ensaio e o pH da solucão, inicialmente ajustado para 5.0, năo foi corrigido no período de absorç̃o.

No inicio e final do ensaio determinou-se o peso do vaso + planta para posterior estimativa da transpiração e correção do volume da solução no vaso, em cada tempo de amostragem. Terminado o ensaio, o sistema radicular foi separado da parte aérea, lavado em água corrente e seco em papel toalha para determinaçăo do peso da matéria fresca, ou seco em estufa a $65 \circ \mathrm{C}$ até peso constante, para determinação do peso da matéria seca.

Uma vez obtida a curva de exaustão do $\mathrm{P}$ da solução em funcão do tempo de absorcão, estimaram-se os parâmetros cinéticos da absorcăo radicular de $\mathrm{P}$ ( $V_{\max } \mathrm{e} \mathrm{K}_{\mathrm{m}}$ ), empregando-se a aproximacáo grafico - matematica proposta por RUIZ (1985). A Cmin foi determinada pela média dos valores de concentraça de $\mathrm{P}$ na soluçăo, que nas amostragens finais do ensaio tenderam a permenecer constantes. Estimados os parâmetros cinéticos, foi possível definir a equaça de Michaelis - Menten e calcular o influxo: $I=\frac{V_{\max } C}{K_{m}+C}$

ou Influxo Iiquido: $I=V_{\max }\left(C-C_{m i n}\right)$

$$
\mathrm{K}_{\mathrm{m}}+\left(\mathrm{C}-\mathrm{C}_{\mathrm{m} 1 \mathrm{n}}\right)
$$

expressos por unidade de peso de matéria fresca ou seca de

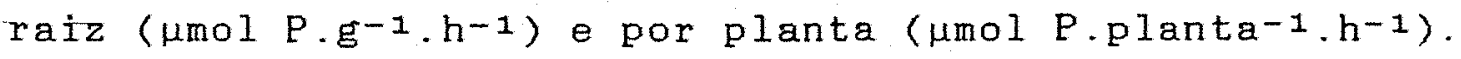




\section{4 - RESULTADOS}

\section{1 - EXPERIMENTO I}

A Figura 1 mostra as curvas de exaustão do $P$ da solução,de acordo com os tratamentos, obtidas pela diminuiça na atividade do $32 \mathrm{P}$ da solução en função do tempo de absorgão. A exaustão do $P$ variou com a dose de $P$ adicionada ao substrato e a presenca da micorriza. A micorrizaça das plantas na menor dose de $P$ ( $P_{1}$ ) exauriu mais rapidamente o $\mathrm{P}$ da solucáo, enquanto na maior dose ( $\mathrm{P}_{2}$ ) a exausta foi mais lenta, principalmente para Glonus etunicatum.

A partir das curvas de exaustão de $\mathrm{P}$ da solução nutritiva determinaram-se os parâmetros cinéticos da absorço radicular de $\mathrm{P}$, cujas equacões de regressão, para ajuste dos dados experimentais, constam do Apêndice 1.

A Tabela 2 demonstra o efeito da dose de $\mathrm{P}$ e da micorrizaço do feijoeiro nos parâmetros cineticos da absorcão de $P$. Os valores de $V_{\max }$ foram influenciados pelo nivel de $P$; considerando-se a velocidade expressa em unidade de peso de matéria seca de raiz, observou-se gue o aumento na dose de $\mathrm{P}$ reduziu $V_{m a x}$ em $20 \%$ nas plantas da testemunha $e$ em $59 \%$ e $34 \%$ nas plantas colonizadas por $G$ etunicatum e $S$. heterogama, respectivamente. A micorrizaço do feijoeiro aumentou a $V_{\max }$ na dose $P_{1}$, mas a reduziu quando as plantas receberam maior dose de $P$, sendo que a maior reduça ocorreu na simbiose com $G$. etunicatun, em torno de $40 \%$, ao passo que com $S$. heterogama, foi ao redor de $5 \%$, comparando-se com $\mathrm{T}-$ $\mathrm{P}_{2}$. $\mathrm{Na}$ dose $\mathrm{P}_{1}$, as micorrizas diminuiram em $15 \%$ o valor do $K_{m}$, demonstrando um aumento de afinidade ao $P$ pelas raizes infectadas, quando comparado com $\mathrm{T}-\mathrm{P}_{1}$; entretanto, em $\mathrm{P}_{2}$ 


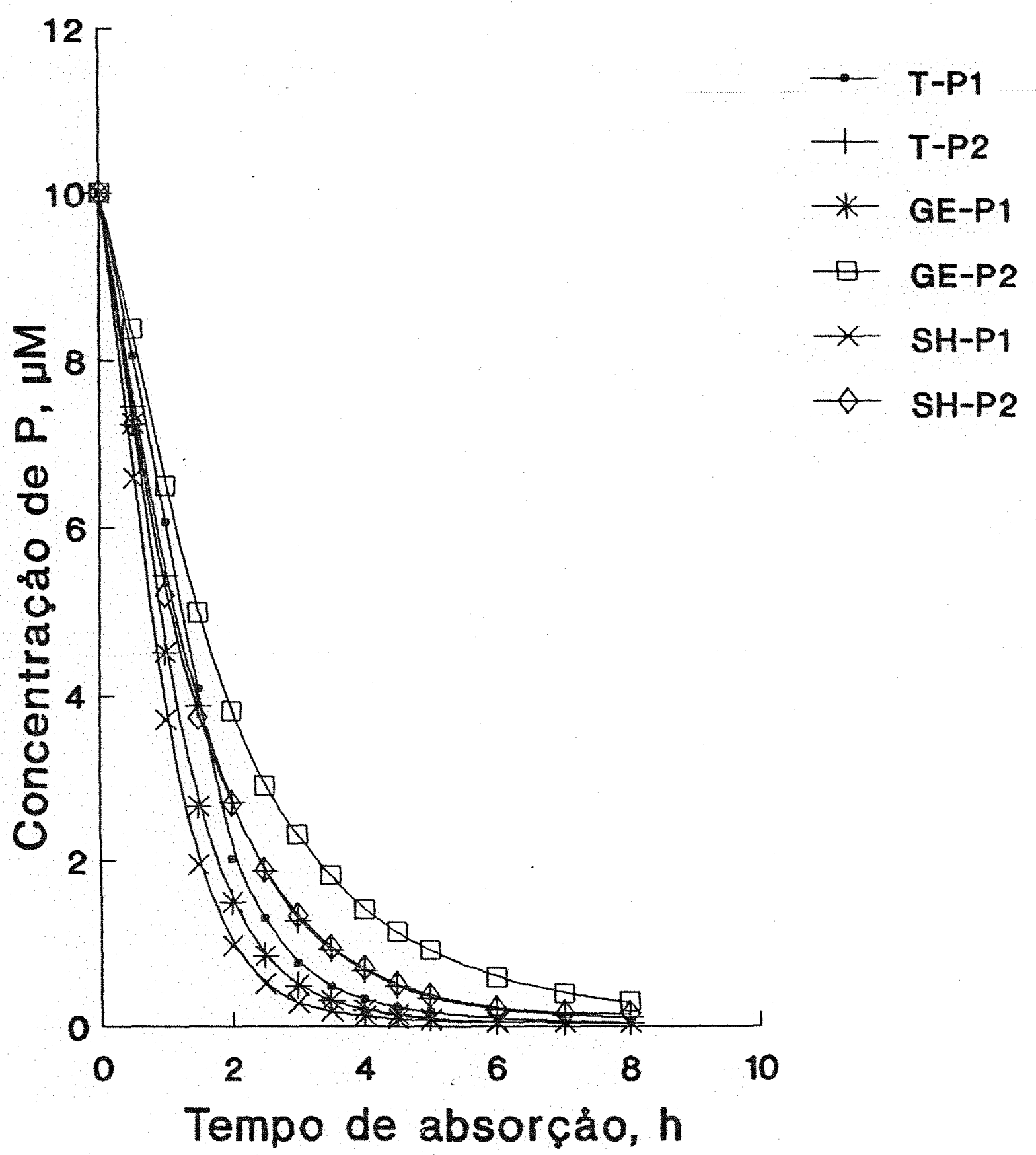

Eigura 1. Curva de exaustão do $\mathrm{P}$ da solução em função do tempo de absorção pelo feijoeiro, na ausencia ( $T$ Testemunha) e presença de micorriza (GE-Glomus etunicatun; SH-Scutellospora heterogama) e com dois niveis de $P$ ( $P_{1}-0.3$ ppm; $P_{2}-3.0 \mathrm{ppm}$ ). 
Tabela 2. Parâmetros cinéticos ( $\left.V_{m a x}, K_{m}, C_{m} n\right)$ de absorção radicular de $P$ e peso da matéria fresca (PMF) e seca (PMS) de raiz de feijoeiro, na ausência ( $T$ Testemunha) e presença de micorriza (GE- Glomus etunicatum; SH- Scutellospora heterogama), com dois niveis de $\mathrm{P}$ ( $\left.\mathrm{P}_{1}-0.3 \mathrm{ppm} ; \mathrm{P}_{2}-3.0 \mathrm{ppm}\right)$. (Médias de três repetiçoes).

\begin{tabular}{|c|c|c|c|c|c|c|c|}
\hline \multirow[t]{3}{*}{ TRATAM. } & \multicolumn{3}{|c|}{$V_{\max }$} & \multirow{3}{*}{$\frac{\mathrm{K}_{\mathrm{m}}}{\mu \mathrm{M}}$} & \multirow{3}{*}{$\frac{C_{m i n}}{\mu M}$} & \multirow{3}{*}{$\frac{\text { PMER }}{g}$} & \multirow{3}{*}{$\frac{\text { PMSR }}{g}$} \\
\hline & & $\mu$ mol $\mathrm{P}$ & & & & & \\
\hline & gMF . h & $\mathrm{pl} \cdot \mathrm{h}$ & gMS.h & & & & \\
\hline$T-P_{1}$ & 0.71 & 10.72 & 10.72 & 2.00 & 0.19 & 15.1 & 1.0 \\
\hline $\mathrm{T}-\mathrm{P}_{2}$ & 0.72 & 11.03 & 8.49 & 2.09 & 0.21 & 15.3 & 1.3 \\
\hline $\mathrm{GE}-\mathrm{P}_{1}$ & 0.85 & 13.38 & 12.16 & 1.71 & 0.08 & 15.7 & 1.1 \\
\hline$G E-P_{2}$ & 0.39 & 8.54 & 5.03 & 2.68 & 0.55 & 22.0 & 1.7 \\
\hline $\mathrm{SH}-\mathrm{P}_{1}$ & 0.87 & 14.61 & 12.18 & 1.63 & 0.12 & 16.8 & 1.2 \\
\hline $\mathrm{SH}-\mathrm{P}_{2}$ & 0.55 & 11.28 & 8.06 & 2.19 & 0.29 & 20.4 & 1.4 \\
\hline
\end{tabular}

ocorreu um aumento no $\mathrm{K}_{\mathrm{m}}$ de $28 \%$ nas plantas colonizadas por $G$. etunicatum e de $5 \%$ naquelas por $S$. heterogama, em relaçăo a $\mathrm{T}-\mathrm{P}_{2}$. 0 comportamento da simbiose nas diferentes doses de $P$ também variou, observando-se que o valor de $\mathrm{K}_{\mathrm{m}}$ foi aumentado em $57 \%$ e $34 \%$ na presença de G. etunicatum e S. heterogama, respectivamente, e em $5 \%$ na testemunha, quando as plantas receberam maior dose de $P$. 
Os valores de $C_{m i n}$ (Tabela 2) variaram da forma semelhante ao $\mathrm{K}_{\mathrm{m}}$, ou seja, comparando-se com $\mathrm{T}-\mathrm{P}_{1}$, ag micorrizas diminuiram a $\mathrm{C}_{\mathrm{m}}$ in em $58 \%$ e $37 \%$, enquanto que em relação a $\mathrm{T}-\mathrm{P}_{2}$, aumentaram em $162 \%$ e $38 \%$, quando estabelecidas por $G$. etunicatun e $S$. heterogana, respectivamente. Levando-se en consideraça o nivel de $P$ aplicado, constatou-se que con o aumento na dose de $F$, a $\mathrm{C}_{\mathrm{min}}$ elevou-se em $11 \%, 558 \%$ e $142 \%$ nas plantas da testemunha e nas simbioses com $G$. etunicatum e $S$. heterogama, respectivamente.

A micorrizaçáo do feijoeiro em $P_{1}$ promoveu um incremento no influxo liquido de $P$, em torno de $20 \%$, em relaça a $T-P_{1}$, quando expresso em unidade de peso de raiz (Figuras 2 e 3 e Tabela 3 ). A aplicaça de uma dose maior de $P$ ao substrato reduziu o influxo, principalmente nas plantas colonizadas por Glomus, que apresentaram um influxo $50 \%$ menor que a testemunha correspondente $\left(\mathrm{T}-\mathrm{P}_{2}\right)$, ao passo que nas plantas em simbiose com Scutellospora, esta reduçá foi de $7 \%$ (influxo por unidade de peso de matéria seca de raiz). G. etunicatum e $S$. heterogama, em $\mathrm{P}_{1}$, promoveram, respectivamente, um influxo liquido de $P$ por unidade de peso de raiz, $176 \%$ e $62 \%$ maior do que o obtido com adiço de $\mathrm{Pz}$, enquanto $\mathrm{T}-\mathrm{P}_{1}$ superou $\mathrm{T}-\mathrm{P}_{2}$ em apenas $28 \%$.

0 influxo líquido de $P$ por planta (Figura 4 e Tabela 3) teve um incremento de $27 \%$ e $42 \%$, quando na presença de Glomus e Scutellospora, respectivamente, comparando-se com $\mathrm{T}-\mathrm{P}_{1}$, do passo que em comparaça a $\mathrm{T}-\mathrm{P}_{2}$, o primeiro endofito reduziu o influxo em $28 \%$ e o segundo năo o alterou. Na dose $\mathrm{P}_{1}$, as plantas micorrizadas por Glomus e Scutellospora apresentaram, respectivamente, um influxo $79 \%$ e $39 \%$ maior que na dose $\mathrm{P}_{2}$, enquanto na testemunha nao houve efeito de nivel de $P$.

$$
\text { As raizes das plantas foram }
$$

significativamente mais colonizadas por $G$. etunicatum do que S. heterogama, na dose $\mathrm{P}_{1}$ (Tabela 4). O aumento na dose de P reduziu, significativamente, a porcentagem do comprimento de 
Tabela 3. Influxo líquido de $P$ por unidade de peso de matéria fresca (MF) e seca (MS) de raiz e por planta, em funçăo da concentração de $P$ na solucão, em feijoeiro não micorrizado ( $T$ - Testemunha) e micorrizado (GE- Glomus etunicatum; $\mathrm{SH}-$ Scutellospora heterogama), com dois níveis de P $\left(\mathrm{P}_{1}-0.3 \mathrm{ppm} ; \mathrm{P}_{2}-3.0 \mathrm{ppm}\right) .1$,

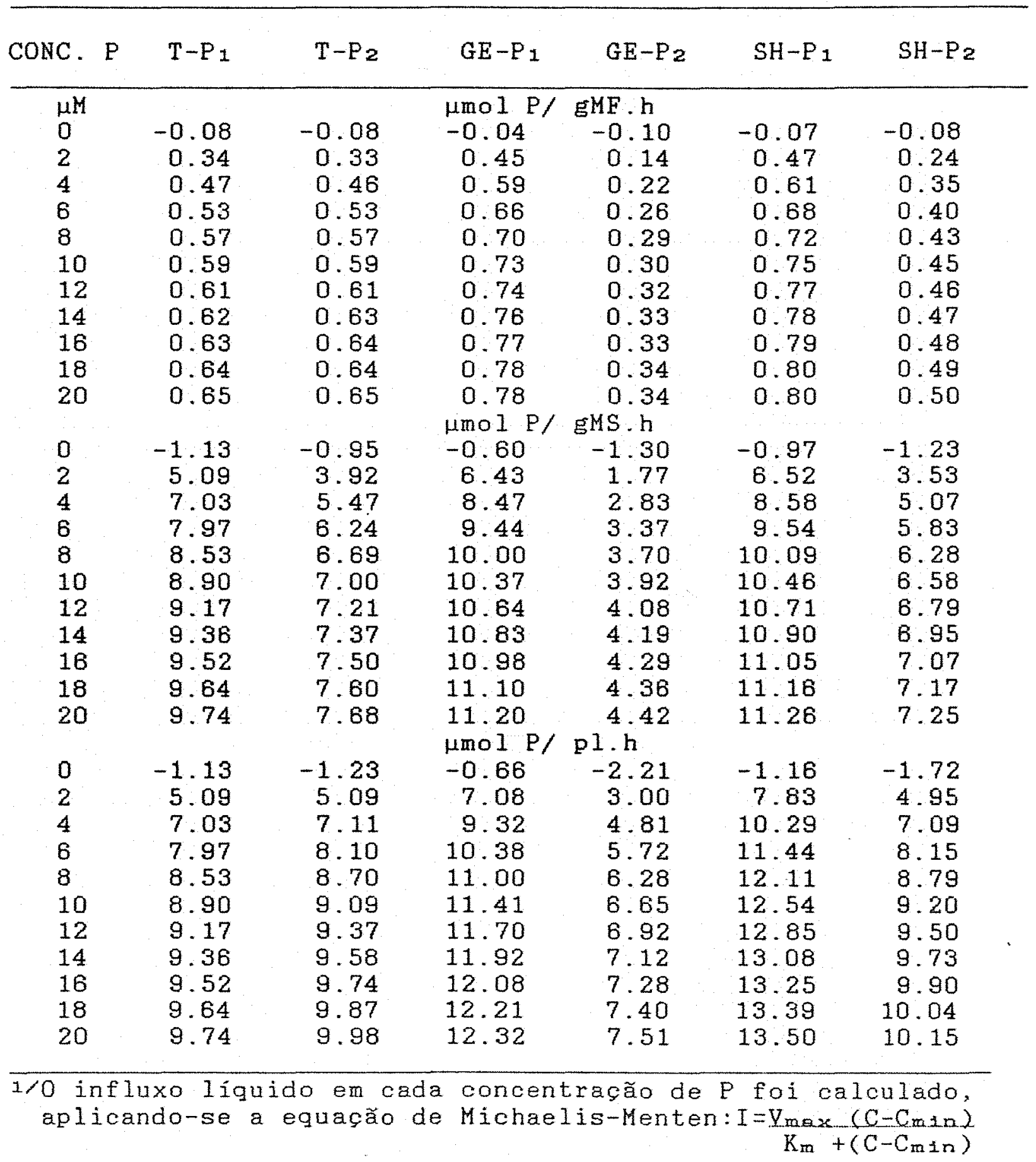




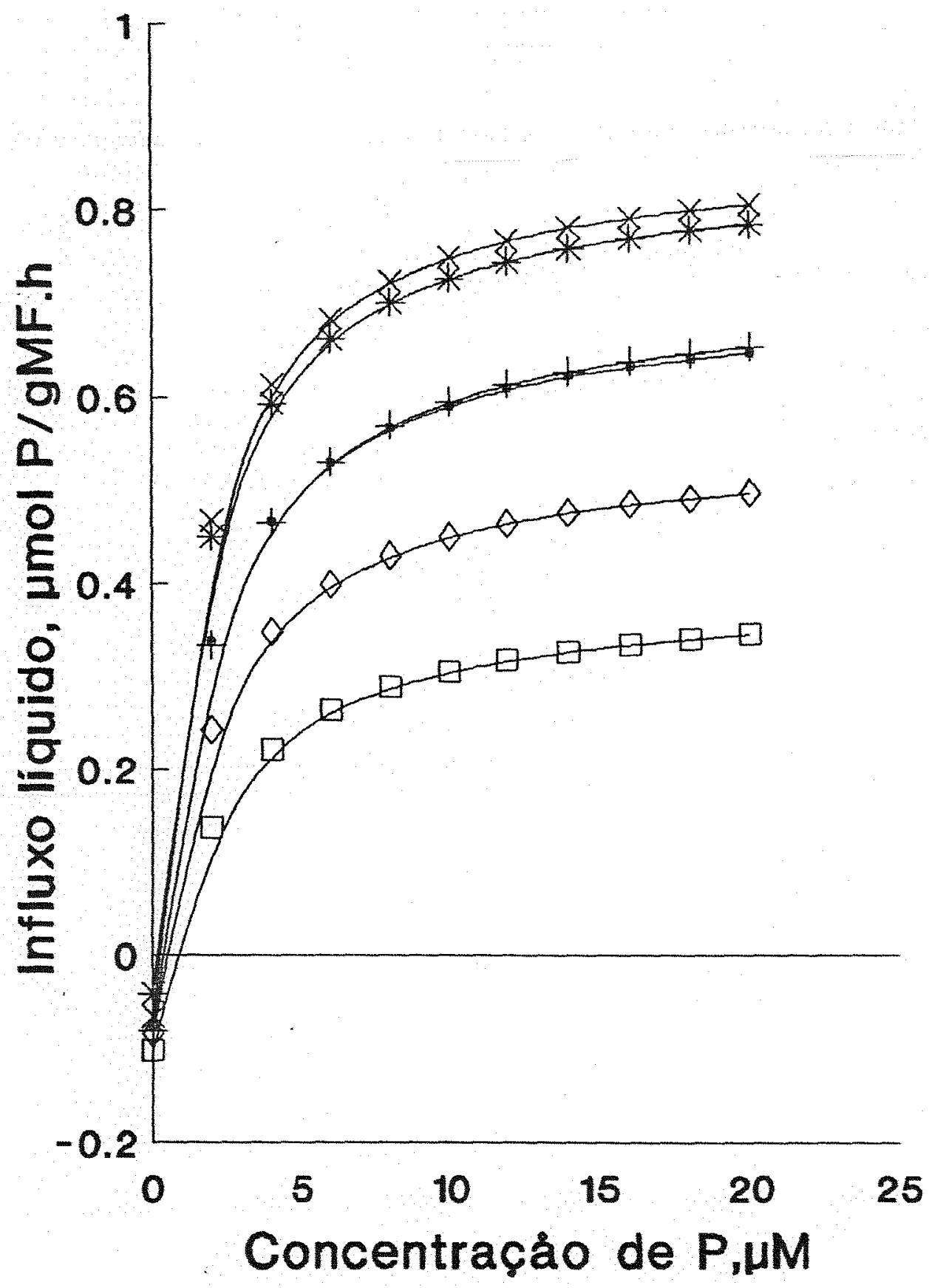

$\rightarrow$ T-P1

+ T-P2

* GE-P1

E CE-P2

$\rightarrow$ SH-PI

$\theta$ SH-P2

Figura 2. Influxo líquido de $P$ por unidade de peso de matéria fresca de raiz, em funcáo da concentracáo de $P$ na solugăo, em feijoeiro, na ausencia ( $T$ Testemunha) e presenca de micorriza (GE-Glomus etunicatun; SH-Scutellospora heterogana) e com dois niveis de $\mathrm{P}$ ( $\mathrm{P}_{1}-0.3$ ppm; $\mathrm{Pz}_{2}-3.0$ ppm). Curvas traçadas de acordo com a equaça de Michaelis - Menten. 


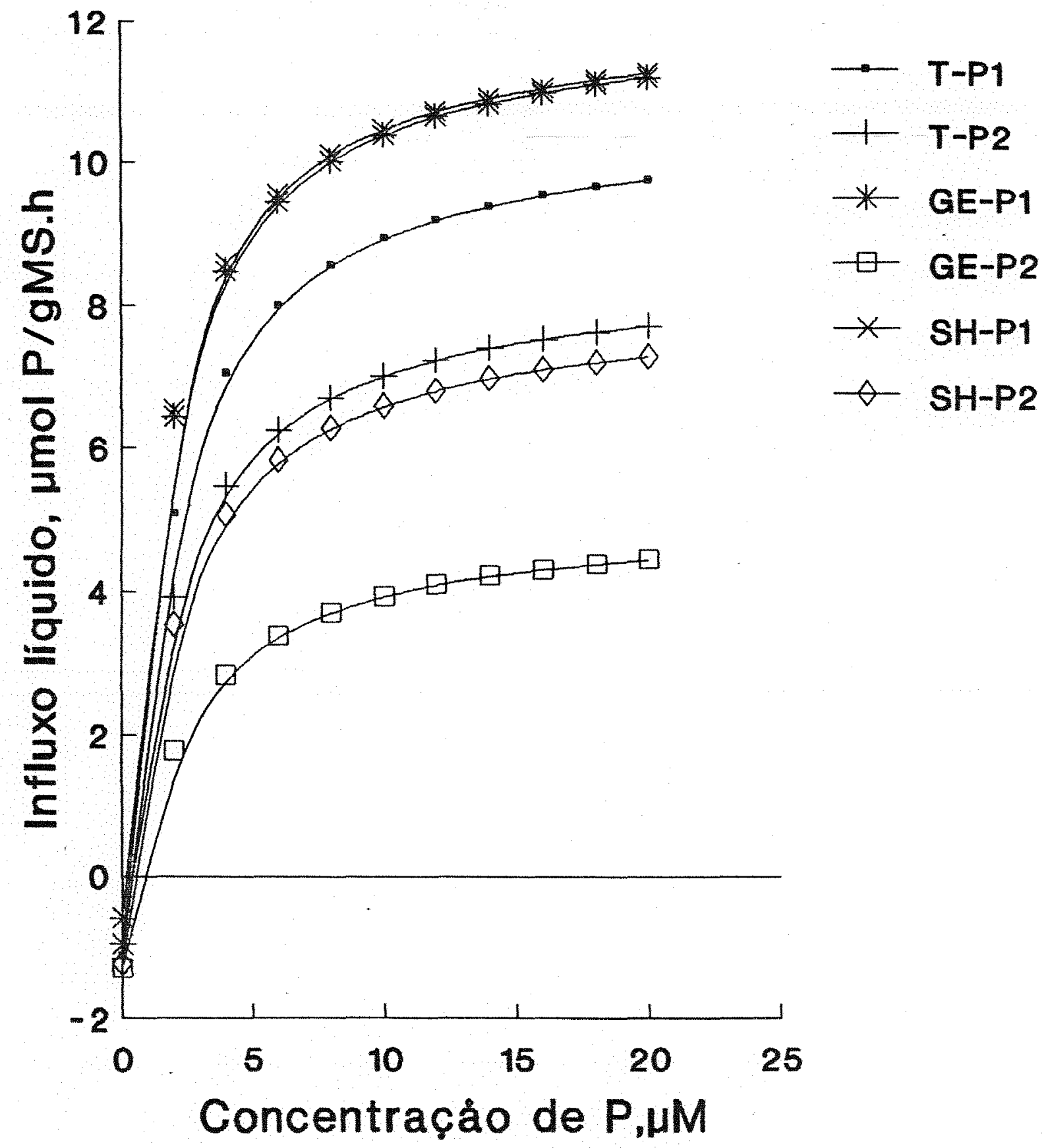

Figura 3. Influxo líguido de $\mathrm{P}$ por unidade de matéria seca de raiz, em funçáo da concentraça de $P$ na soluça, em feijoeiro não micorrizado (TTestemunha) e micorrizado (GE- Glomus etunicatum; SH- Scutellospora heterogama), com dois niveis de $\mathrm{P}$ ( $\mathrm{P}_{1}-0.3 \mathrm{ppm} ; \mathrm{P}_{2}-3.0 \mathrm{ppm}$ ). Curvas tracadas de acordo com a equaça de Michaelis - Menten. 


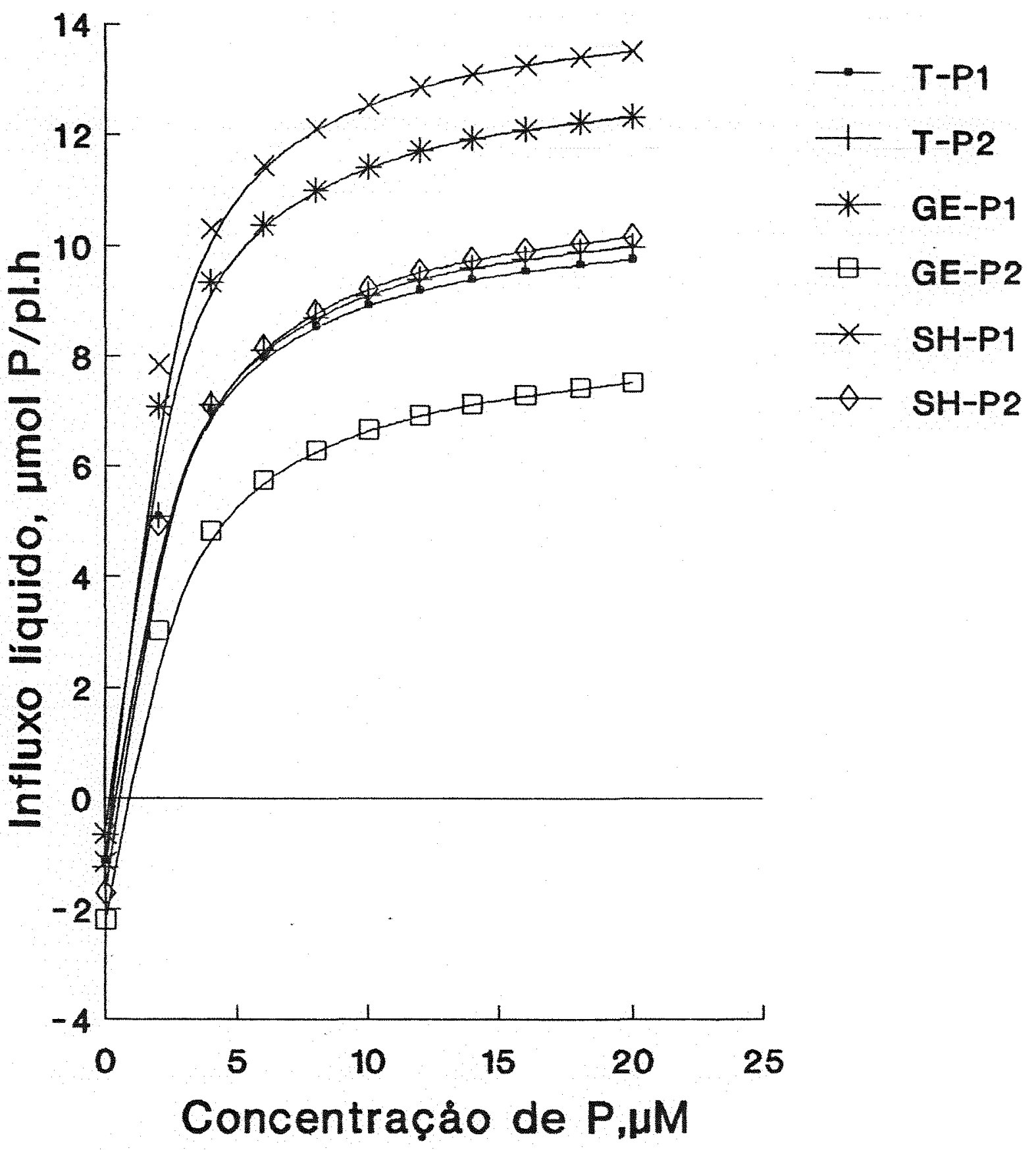

Figura 4. Influxo líquido de $P$ por planta, em funça da concentração de $P$ na soluçao, em feijoeiro não micorrizado ( $T$ - Testemunha) e micorrizado (GEGlomus etunicatum; SH- Scutellospora heterogama) com dois niveis de $\mathrm{P}$ aplicado ( $\mathrm{F}_{1}-0.3 \mathrm{ppm} ; \mathrm{P}_{2}-$ $3.0 \mathrm{ppm}$ ). Curvas traçadas segundo a equaça de Michaelis - Menten. 
raiz infectada pelo primeiro fungo, não alterando, entretanto, a do segundo.

Tabela 4. Peso da matéria seca da parte aérea (PMSPA), peso da matéria seca dos nódulos (PMSNOD) e porcentagem de infecção na raiz de feijoeiro não micorrizado ( $\mathrm{T}$ - Testemunha) e micorrizado (GE- Glomus etunicatum; SH- Scutellospora heterogama), com dois niveis de $\mathrm{P} \quad\left(\mathrm{P}_{1}-0.3 \quad \mathrm{ppm} ; \mathrm{Pl}_{2}-3.0\right.$ ppm). (Médias de 6 repetiços). 1

\begin{tabular}{|c|c|c|c|}
\hline TRATAMENTOS & PMSPA & PMSNOD & INEECCAO \\
\hline & g & $\mathrm{mg}$ & $\%$ \\
\hline $\mathrm{T}-\mathrm{P}_{1}$ & $1.15 c$ & $14.64 \mathrm{c}$ & Oo \\
\hline $\mathrm{T}-\mathrm{P}_{2}$ & $1.82 \mathrm{ab}$ & $47.08 \mathrm{~b}$ & Oc \\
\hline $\mathrm{GE}-\mathrm{P}_{1}$ & $1.73 \mathrm{ab}$ & $60.02 b$ & $60 a$ \\
\hline$G E-P_{2}$ & $1.87 \mathrm{a}$ & $107.16 a$ & $46 b$ \\
\hline $\mathrm{SH}-\mathrm{P}_{1}$ & $1.30 \mathrm{bc}$ & $15.66 \mathrm{c}$ & $38 \mathrm{~b}$ \\
\hline $\mathrm{SH}-\mathrm{Pz}$ & $1.90 \mathrm{a}$ & $44.38 \mathrm{~b}$ & $39 \mathrm{~b}$ \\
\hline $\begin{array}{l}\mathrm{F}^{2} / \\
\mathrm{CV}\end{array}$ & $\begin{array}{l}7.03^{* *} \\
18.19\end{array}$ & $\begin{array}{l}46.23^{* *} \\
23.30\end{array}$ & $\begin{array}{c}353.62^{* *} \\
10.30\end{array}$ \\
\hline
\end{tabular}

1/Médias seguidas por letras iguais na diferem entre si pelo teste de Tukey a $5 \%$.

$2 / * *$-Teste $F$ significativo a $1 \%$. 
Com relacá ao crescimento das plantas (Tabela 4), observou-se que $P_{2}$ promoveu um aumento significativo na produção de matéria seca da parte aérea, na testemunha e na presenca de $S$. heterogama, mas náo de $G$. etunicatun. 0 crescimento causado por este endófito nao diferiu com a dose de $\mathrm{P}$ e nem de T-Pz. A planta micorrizada por Glomus na dose $\mathrm{P}_{1}$ diferiu de $\mathrm{T}-\mathrm{P}_{1}$, o que nåo ocorreu com S. heterogama.

Independente de estarem ou não micorrizadas, as plantas que receberam maior dose de $P$ apresentaram significativamente maior nodulação (Tabela 4). As plantas infectadas por $G$. etunicatun, na dose $\mathrm{Pz}$, tiveram nodulaça significativamente maior que todos os demais tratamentos. Tanto em $\mathrm{P}_{1}$ como em $\mathrm{P}_{2}, S$. heterogana não diferiu da testemunha, mas foi superado significativamente por $G$. etunicatum, que gerou um incremento na nodulaçáo, em torno de $300 \%$ e $130 \%$, respectivamente. Enquanto a testemunha e Scutellospora aumentaram a nodulaçăo em $200 \%$ com a adição de Pz ao substrato, Gloaus somente a incrementou em $79 \%$.

Com excecáo do $\mathrm{P}$, os teores de $\mathrm{N}, \mathrm{K}, \mathrm{Ca}$ e $\mathrm{Mg}$ na parte aérea do feijoeiro apresentaram um aparente efeito de diluiçăo, en funçăo do maior crescimento das plantas (Tabela 5). O teor de $P$, entretanto, foi significativamente maior nas plantas colonizadas pelo Glomus, na maior dose de $\mathrm{P}$, superando $\mathrm{T}-\mathrm{P}_{2}$ em $20 \%, \mathrm{~T}-\mathrm{P}_{1}$ em $64 \%$ e $\mathrm{G}-\mathrm{P}_{1}$ em $39 \%$. As plantas da testemunha e as colonizadas por $G$. etunicatum que receberam $\mathrm{P}_{2}$, superaram significativamente aquelas com $\mathrm{P}_{1}$, enquanto as colonizadas por $S$. heterogana nå diferiram quanto à dose de $P$. Em relação à quantidade acumulada na parte aérea (Tabela 5), constatou-se que na dose $P_{1}$ os fungos micorrizicos năo diferiram da testemunha, com excecão do $P$, cujo acumúlo nas plantas colonizadas pelo Glomus foi significativamente maior $(100 \%)$ que $\mathrm{T}-\mathrm{P}_{1}$. Glomus e Scutellospora geraram, respectivamente, aumentos de $46 \%$ e $67 \%$ para o P, $48 \%$ e $25 \%$ no Ca e $47 \%$ e $29 \%$ no $\mathrm{Mg}$, com adiça de $\mathrm{Pz}$. De modo geral, as plantas cultivadas com maior dose 
Tabela 5. Teor e quantidade acumulada de $\mathrm{N}, \mathrm{P}, \mathrm{K}, \mathrm{Ca}$ e $\mathrm{Mg}$ na parte aérea" de feijoeiro na ausência (TTestemunha) e presenca de micorriza (GE-Glomus etunicatum; SH- Scutellospora heterogama), com dois niveis de $\mathrm{P} \quad\left(\mathrm{P}_{1}-0.3\right.$ ppm; $\mathrm{Pz}_{2}-3.0$ ppm). (Médias de 6 repetiçres). $1 /$

\begin{tabular}{|c|c|c|c|c|c|}
\hline TRATAM & $\mathrm{N}$ & $\mathrm{P}$ & $\mathrm{K}$ & $\mathrm{Ca}$ & $\mathrm{Mg}$ \\
\hline \multicolumn{6}{|c|}{ TEOR (\%) } \\
\hline $\begin{array}{l}T-P_{1} \\
T-P_{2} \\
G E-P_{1} \\
G E-P_{2} \\
S H-P_{1} \\
S H-P_{2}\end{array}$ & $\begin{array}{l}2.89 \mathrm{a} \\
1.90 \mathrm{bc} \\
1.64 \mathrm{c} \\
1.87 \mathrm{bc} \\
2.15 \mathrm{~b} \\
1.87 \mathrm{bc}\end{array}$ & $\begin{array}{l}0.11 \mathrm{~d} \\
0.15 \mathrm{~b} \\
0.13 \mathrm{bc} \\
0.18 \mathrm{a} \\
0.12 \mathrm{~cd} \\
0.14 \mathrm{bc}\end{array}$ & $\begin{array}{l}2.54 \mathrm{a} \\
1.63 \mathrm{c} \\
1.83 \mathrm{c} \\
1.69 \mathrm{bc} \\
2.21 \mathrm{ab} \\
1.66 \mathrm{c}\end{array}$ & $\begin{array}{l}1.62 \mathrm{a} \\
1.35 \mathrm{ab} \\
1.12 \mathrm{~b} \\
1.43 \mathrm{ab} \\
1.51 \mathrm{a} \\
1.31 \mathrm{ab}\end{array}$ & $\begin{array}{l}0.35 a \\
0.23 c \\
0.25 b c \\
0.32 a b \\
0.27 a b c \\
0.27 a\end{array}$ \\
\hline \multirow[t]{2}{*}{$\begin{array}{l}\mathrm{F}^{2} \\
\mathrm{CV}(\%)\end{array}$} & $\begin{array}{c}11.53^{*} \\
5.83\end{array}$ & $\begin{array}{c}18.54^{* *} \\
4.52\end{array}$ & $\begin{array}{l}9.48^{* *} \\
7.24\end{array}$ & $\begin{array}{l}4.04^{* *} \\
7.04\end{array}$ & $\begin{array}{l}5.79^{*} \\
7.45\end{array}$ \\
\hline & & QUANTIDADE & ACUMULADA & (mg) & \\
\hline $\begin{array}{l}T-P_{1} \\
T-P_{2} \\
G E-P_{1} \\
G E-P_{2} \\
S H-P_{1} \\
S H-P_{2}\end{array}$ & $\begin{array}{l}30.4 \mathrm{ab} \\
35.8 \mathrm{a} \\
28.7 \mathrm{ab} \\
35.6 \mathrm{ab} \\
25.7 \mathrm{~b} \\
32.6 \mathrm{ab}\end{array}$ & $\begin{array}{l}1.2 \mathrm{~d} \\
2.8 \mathrm{ab} \\
2.4 \mathrm{bc} \\
3.5 \mathrm{a} \\
1.5 \mathrm{~cd} \\
2.5 \mathrm{~b}\end{array}$ & $\begin{array}{l}26.7 a b \\
30.3 a b \\
28.8 a b \\
34.0 a \\
25.1 b \\
27.4 a b\end{array}$ & $\begin{array}{l}16.1 \mathrm{c} \\
25.1 \mathrm{a} \\
18.3 \mathrm{bc} \\
27.0 \mathrm{a} \\
18.2 \mathrm{bc} \\
22.7 \mathrm{ab}\end{array}$ & $\begin{array}{l}3.9 b c \\
4.3 b c \\
4.3 b c \\
6.3 a \\
3.5 c \\
4.5 b\end{array}$ \\
\hline $\begin{array}{l}F \\
\mathrm{CV}(\%)\end{array}$ & $\begin{array}{c}2.97^{*} \\
16.44\end{array}$ & $\begin{array}{l}16.80^{* *} \\
19.51\end{array}$ & $\begin{array}{c}2.42^{*} \\
15.72\end{array}$ & $\begin{array}{c}9.48^{* *} \\
14.86\end{array}$ & $\begin{array}{c}29.13^{* *} \\
9.13\end{array}$ \\
\hline
\end{tabular}

1/Médias seguidas da mesma letra năo diferem entre si pelo teste de Tukey a $5 \%$.

$2 / *$ e $* *$ - Teste $F$ significativo a $5 \%$ e $1 \%$, respectivamente. 
de $\mathrm{P}$ tenderam a acumular mais $\mathrm{N}, \mathrm{P}, \mathrm{K}, \mathrm{Ca}$ e $\mathrm{Mg}$ na parte aérea, principalmente aquelas infectadas pelo Glomus, embora só tenha ocorrido diferença significativa no acúmulo de $\mathrm{Mg}$ ( $47 \%$ de incremento, em relaçăo a $\mathrm{T}-\mathrm{P}_{2}$ e $S$. heterogama).

o teor de $\mathrm{Zn}, \mathrm{Cu}$ e Mn na parte aérea do feijoeiro foi significativamente maior na testemunha ( $T-\mathrm{P}_{1}$ ) que nos demais tratamentos (Tabela 6). As plantas colonizadas por $S$. heterogama tiveram os menores acúmulos de Zn e Cu, em média $34 \%$. As micorrizas com $G$. etunicatum e $\mathrm{T}-$ $\mathrm{P}_{2}$ apresentaram os maiores acúmulos de $\mathrm{Fe}, \mathrm{Zn}_{\mathrm{n}} \mathrm{Cu}$. Houve significativamente menor acúmulo de Mn na parte aérea das micorrizas estabelecidas na dose $P_{1}$, sendo que esta reduça foi de $36 \%$ e $52 \%$, em relação a Glomus e Scutellospora, comparando-se com $\mathrm{T}-\mathrm{P}_{1}$. Na maior dose de $\mathrm{P}$, entretanto, os endófitos năo diferiram da testemunha no acúmulo de Mn.

\section{2- EXPERIMENTO II}

Verificou-se que a exaustăo do $\mathrm{P}$ da solução nutritiva pelas plantas colonizadas pelo G. etunicatun foi mais rápida do que a testemunha e as colonizadas por $S$. heterogana (Figura 5). Na cultivar (cv) Negro Argel, a diferença no comportamento dos endófitos foi mais acentuada que na Carioca.

0 efeito da micorriza nos parâmetros cinéticos da absorção de $P$ pelo feijoeiro, estimados a partir das curvas de ajuste do Apêndice 2, pode ser observado na Tabela 7. Na cv Carioca observou-se que a micorrizaço com $G$. etunicatum aumentou a $V_{\max }$ em $22 \%$ e $70 \%$, quando expressa por unidade de peso de matéria seca de raiz, $18 \%$ e $53 \%$, considerando-se por unidade de peso de matéria fresca e em $64 \%$ e $54 \%$, quando expressa por planta, em relaça a $\mathrm{T}-\mathrm{P}_{1}$ e $\mathrm{T}-\mathrm{P}_{2}$, respectivamente. A colonizacăo dessa cv por $S$. heterogama, entretanto, năo ammentou a $V_{m a x .}$ 
Tabela 6. Teor e quantidade acumulada de $\mathrm{Fe}, \mathrm{Zn}, \mathrm{Cu}$ e Mn na parte aérea do feijoeiro, na ausência ( $\mathrm{T}$ Testemunha) e presença de micorriza (GE- Glomus etunicatum; SH- Scutellospora heteragama), com dois niveis de $\mathrm{P}$ ( $\mathrm{P}_{1}-0.3$ ppm; $\mathrm{P}_{2}-3.0$ ppm). (Médias de 6 repetiços). 1 ,

\begin{tabular}{|c|c|c|c|c|c|}
\hline TRATAMENTOS & $\mathrm{Fe}$ & $\mathrm{Zn}$ & $\mathrm{Cu}$ & $\mathrm{Mn}$ & 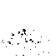 \\
\hline \multicolumn{6}{|c|}{ TEOR (ppm) } \\
\hline $\begin{array}{l}\mathrm{T}-\mathrm{P}_{1} \\
\mathrm{~T}-\mathrm{P}_{2} \\
\mathrm{GE}-\mathrm{P}_{1} \\
\mathrm{GE}-\mathrm{P}_{2} \\
\mathrm{SH}-\mathrm{P}_{1} \\
\mathrm{SH}-\mathrm{P}_{2}\end{array}$ & $\begin{array}{l}155 \mathrm{a} \\
129 \mathrm{abc} \\
118 \mathrm{bc} \\
148 \mathrm{ab} \\
102 \mathrm{c} \\
105 \mathrm{c}\end{array}$ & $\begin{array}{l}70.4 \mathrm{a} \\
48.8 \mathrm{~b} \\
49.1 \mathrm{~b} \\
48.2 \mathrm{~b} \\
45.7 \mathrm{~b} \\
33.0 \mathrm{~b}\end{array}$ & $\begin{array}{r}15.7 \mathrm{a} \\
7.8 \mathrm{~b} \\
8.8 \mathrm{~b} \\
7.9 \mathrm{~b} \\
7.4 \mathrm{~b} \\
6.4 \mathrm{~b}\end{array}$ & $\begin{array}{l}964 \mathrm{a} \\
433 \mathrm{~b} \\
441 \mathrm{~b} \\
637 \mathrm{~b} \\
438 \mathrm{~b} \\
452 \mathrm{~b}\end{array}$ & \\
\hline $\begin{array}{l}\mathrm{F}^{2} \\
\mathrm{CV}(\%)\end{array}$ & $\begin{array}{l}7.19 * * \\
14.53\end{array}$ & $\begin{array}{l}8.11^{* *} \\
19.10\end{array}$ & $\begin{array}{l}15.62^{* *} \\
21.44\end{array}$ & $\begin{array}{l}12.9 * * \\
23.22\end{array}$ & - \\
\hline . & \multicolumn{5}{|c|}{ QUANTIDADE ACUMULADA ( $\mu \mathrm{g}\rangle$} \\
\hline $\begin{array}{l}\mathrm{T}-\mathrm{P}_{1} \\
\mathrm{~T}-\mathrm{P}_{2} \\
\mathrm{GE}-\mathrm{P}_{1} \\
\mathrm{GE}-\mathrm{P}_{2} \\
\mathrm{SH}-\mathrm{P}_{1} \\
\mathrm{SH}-\mathrm{P}_{2}\end{array}$ & $\begin{array}{l}163 \mathrm{~cd} \\
234 \mathrm{ab} \\
194 \mathrm{bc} \\
282 \mathrm{a} \\
123 \mathrm{~d} \\
192 \mathrm{bcd}\end{array}$ & $\begin{array}{l}75.4 a b \\
91.8 \mathrm{a} \\
86.9 \mathrm{a} \\
95.3 \mathrm{a} \\
54.2 \mathrm{~b} \\
57.1 \mathrm{~b}\end{array}$ & $\begin{array}{c}15.7 \mathrm{a} \\
14.0 \mathrm{ab} \\
14.9 \mathrm{ab} \\
17.0 \mathrm{a} \\
8.4 \mathrm{c} \\
11.0 \mathrm{bc}\end{array}$ & $\begin{array}{c}1085 a b \\
773 b c \\
695 c \\
1163 a \\
521 c \\
857 a b c\end{array}$ & \\
\hline $\begin{array}{l}\mathrm{E} \\
\mathrm{CV}(\%)\end{array}$ & $\begin{array}{l}12.00^{* * *} \\
17.97\end{array}$ & $\begin{array}{l}13.51^{* *} \\
13.98\end{array}$ & $\begin{array}{l}10.61^{* *} \\
16.48\end{array}$ & $\begin{array}{l}9.31^{* * *} \\
20.84\end{array}$ & \\
\hline $\begin{array}{r}\text { 1/Médias seg } \\
\text { teste de }\end{array}$ & $\begin{array}{l}\text { as da mesma } \\
\text { y a } 5 \% \text {. }\end{array}$ & Letra não & diferem entre & si pelo & \\
\hline
\end{tabular}




\section{Carioca}

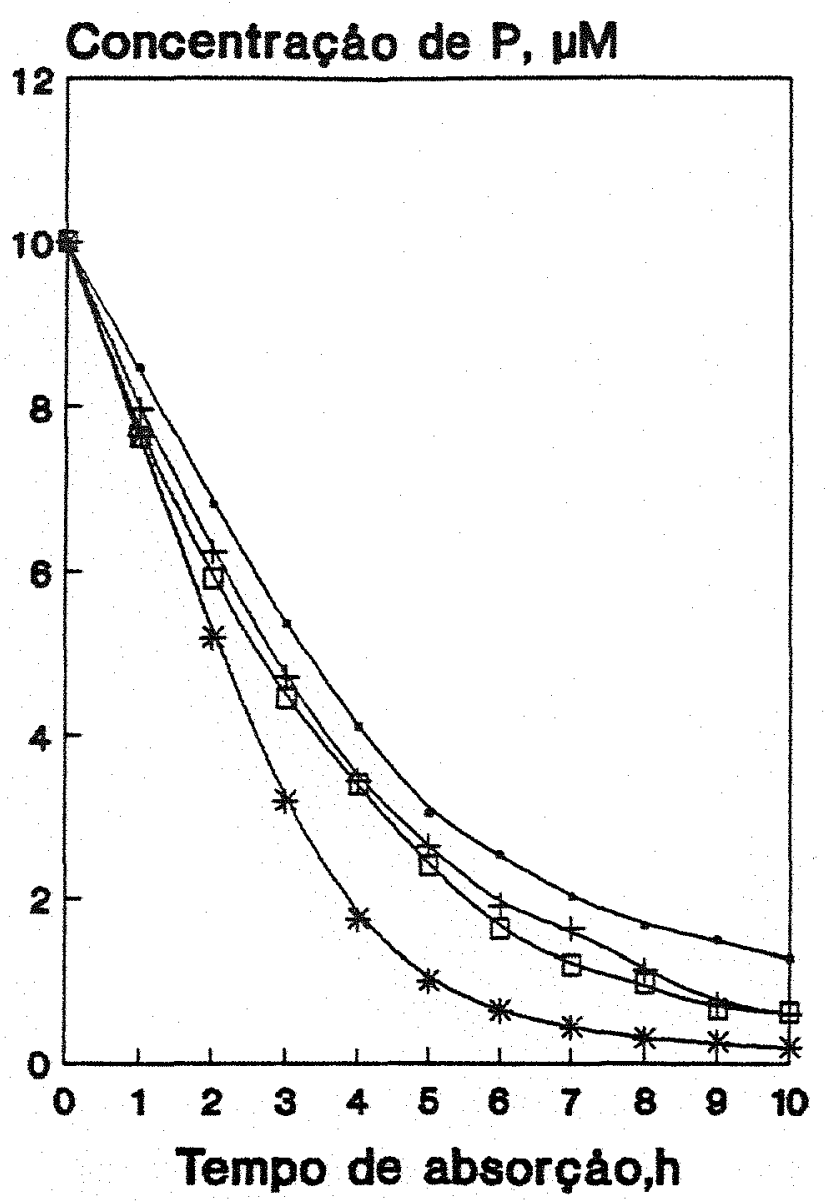

Negro Argel

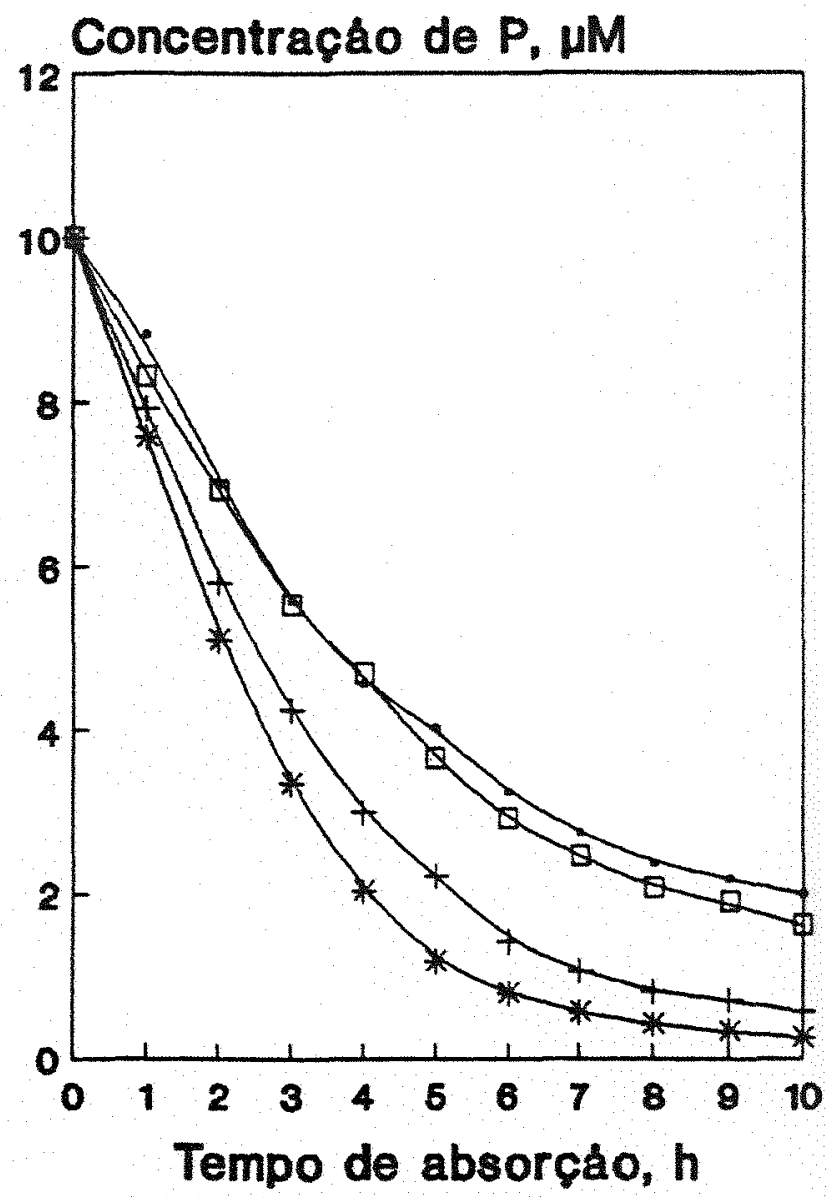

$\rightarrow T-P 1+T-P 2 \quad *$ GE $\square S H$

Figura 5. Curva de exaustão de $\mathrm{P}$ da solução em função do tempo de absorcão, por duas cultivares de feijão (Carioca e Negro Argel) na ausência ( $\mathrm{T}-\mathrm{P}_{1}$ Testemunha com 0.3 ppm $\mathrm{P} ; \mathrm{T}-\mathrm{P}_{2}-$ Testemunha com 3.0 ppm P) e presenca de micorriza (GE-Glomus etunicatun; SH- Scutellospora heterogana). 
Tabela 7. Parâmetros cinéticos da abeorọo radicular de $P$ ( $V_{\max }, K_{m}, C_{m 1 n}$ ) e peso da materia fresca (MF) e seca (MS) de raiz de duas cultivares de feijão (Carioca e Negro Argel) na ausência ( $\mathrm{T}-\mathrm{P}_{1}$ Testemunha com 0.3 ppmP; $\mathrm{T}-\mathrm{P}_{2}-$ Testemunha com 3.0 ppm P) e presenca de micorriza (GE- Glomus etunicatum; SH-Scutellospora heterogama). (Médias de três rẹptições).

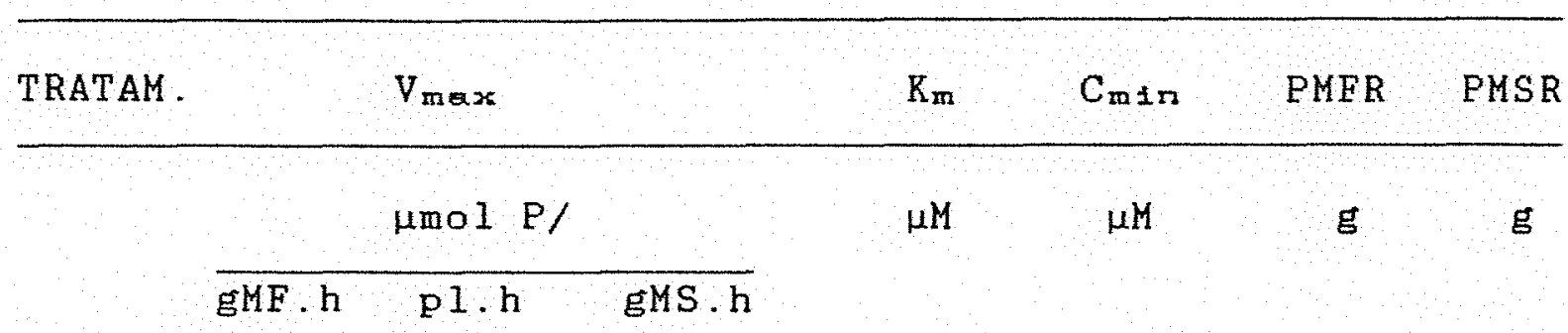

CARIOCA

$\begin{array}{llllllll}\mathrm{T}-\mathrm{P}_{1} & 0.39 & 3.85 & 2.32 & 3.09 & 1.03 & 9.9 & 1.7 \\ \mathrm{~T}-\mathrm{P}_{2} & 0.30 & 4.10 & 1.67 & 2.80 & 0.84 & 13.9 & 2.5 \\ \mathrm{GE} & 0.46 & 6.31 & 2.84 & 1.91 & 0.21 & 13.8 & 2.2 \\ \mathrm{SH} & 0.33 & 3.67 & 2.00 & 1.89 & 0.75 & 11.4 & 1.9\end{array}$

NEGRO ARGEL

\begin{tabular}{llllllll}
$\mathrm{T}-\mathrm{P}_{1}$ & 0.39 & 3.81 & 2.75 & 4.17 & 1.62 & 9.9 & 1.4 \\
$\mathrm{~T}-\mathrm{P} 2$ & 0.38 & 4.91 & 2.57 & 3.10 & 0.69 & 12.9 & 1.9 \\
$\mathrm{GE}$ & 0.43 & 6.01 & 2.37 & 2.05 & 0.24 & 14.1 & 2.6 \\
$\mathrm{SH}$ & 0.44 & 3.41 & 2.50 & 2.50 & 1.42 & 8.2 & 1.4 \\
\hline
\end{tabular}


Já na ev Negro Argel, Glomus promoveu incremento na $V_{\max }$ por. planta, de $58 \%$ e $22 \%$, comparando-se com $\mathrm{T}-\mathrm{P}_{1}$ e T-P2; quando expressa por unidade de peso de matéria seca de raiz, praticamente năo houve diferença entre os tratamentos, enquanto que por unidade de matéria fresca, ambos os endófitos superaram, em torno de $10 \%$, as testemunhas.

A micorrizacăo do feijoeiro diminuiu o valor do $\mathrm{K}_{\mathrm{m}}$ (Tabela 7). Na cv Carioca, esse decréscimo foi em média $35 \%$, para ambos endófitos e em relação às testemunhas. Entretanto, na Negro Argel a reducäo foi maior, ou seja, $51 \%$ e $34 \%$ para Glonus e $40 \%$ e $20 \%$ para Scutellospora, en relaça a $\mathrm{T}-\mathrm{P}_{1}$ e $\mathrm{T}-\mathrm{P}_{2}$, respectivamente. Os valores de $\mathrm{K}_{\mathrm{m}}$ foram menores na cv Carioca comparando-se com Negro Argel, sendo que as maiores diferenças ocorreram en $\mathrm{T}-\mathrm{P}_{1} \mathrm{e}$ nas colonizadas por Scutellospora.

A simbiose Carioca-G. etunicatum reduziu a $\mathrm{C}_{\mathrm{m} 1 \mathrm{n}}$ em $80 \%$ e $75 \%$, respectivamente em relaçă a $\mathrm{T}-\mathrm{P}_{1}$ e $\mathrm{T}-\mathrm{P}_{2}$, enquanto que na presença de $S$. heterogama, a reduçáoficou em torno de $27 \%$ (Tabela 7). Na presenca de GIomus, a $\mathrm{C}_{\mathrm{m}}$ ) foi $72 \%$ menor que com Scutellospora. A cv Negro Argel em simbiose com o primeiro endófito apresentou uma $C_{m} 1 n 85 \%$ e 65\% menor que $\mathrm{T}-\mathrm{P}_{1}$ e $\mathrm{T}-\mathrm{P}_{2}$, respectivamente. Entretanto, esta cultivar quando colonizada por S. heterogama alcancou uma $\mathrm{C}_{\mathrm{m} 1 \mathrm{n}}$ semelhante a $\mathrm{T}-\mathrm{P}_{1}$ e $100 \%$ superior a $\mathrm{T}-\mathrm{P}_{2}$.

De modo Eeral, a micorrizaça do feijoeiro promoveu maior influxo líquido de $\mathrm{P}$ (Figura 6,7 e 8; Tabela 8). O influxo por unidade de peso de matéria fresca de raiz (Figura B), na cv Carioca, em relacăo a $T-P_{1}$, foi incrementado em $46 \%$ na presença de $G$. etunicatum, não havendo, entretanto, incremento com $S$. heterogana. Com relacão à $\mathrm{T}-\mathrm{Pz}$, no entanto, o influxo foi aumentado em $77 \%$ com Glomus e 21\%, com Scutellospora. Já na cv Negro Argel, ambos os fungos causaram um aumento de $46 \%$ no influxo, comparando - se com $\mathrm{T}-\mathrm{P}_{1}$, ao passo que $\mathrm{T}-\mathrm{P}_{2}$ foi superada por $G$. etunicatum em $31 \%$ e $S$. heterogana, em $13 \%$. 
Tabela 8. Influxo líquido de $P$ por unidade de.peso matéria fresca (MF) e seca (MS) de raiz e por planta, em função da concentracão de $P$ na soluço, em duas cultivares de feijão (Carioca e Negro Argel) na ausencia ( $\mathrm{T}-\mathrm{P}_{1}-$ Testemunha com 0.3 ppm $\mathrm{P}: \mathrm{T}-\mathrm{P}_{2}-$ Testemunha com 3.0 ppm P) e presença de micorriza (GE-Glonus etunicatum; SH- Scutellospora heterogama). 1/

\begin{tabular}{|c|c|c|c|c|c|c|c|c|c|}
\hline \multicolumn{2}{|c|}{ CONC.P. } & \multicolumn{2}{|c|}{ CARIOCA } & \multirow[b]{2}{*}{ SH } & \multirow[b]{2}{*}{$\mathrm{T}-\mathrm{P}_{1}$} & \multirow{2}{*}{$\begin{array}{l}\text { NEGRO } \\
\mathrm{T}-\mathrm{Pz}_{2}\end{array}$} & ARGEL & \multirow[b]{2}{*}{ SH } & \\
\hline & $\mathrm{T}-\mathrm{P}_{1}$ & $\mathrm{~T}-\mathrm{P}_{2}$ & $\mathrm{GE}$ & & & & $G E$ & & \\
\hline$\mu M$ & & & & umo 1 & P/gMF.h & & & & \\
\hline 0 & -0.19 & -0.13 & -0.06 & -0.22 & -0.25 & -0.11 & -0.06 & -0.58 & \\
\hline 2 & 0.09 & 0.09 & 0.22 & 0.13 & 0.03 & 0.11 & 0.20 & 0.08 & \\
\hline 4 & 0.19 & 0.16 & 0.31 & 0.21 & 0.14 & 0.20 & 0.28 & 0.22 & \\
\hline 6 & 0.24 & 0.20 & 0.35 & 0.24 & 0.20 & 0.24 & 0.32 & 0.28 & \\
\hline 8 & 0.27 & 0.22 & 0.37 & 0.26 & 0.24 & 0.27 & 0.34 & 0.32 & \\
\hline 10 & 0.29 & 0.23 & 0.39 & 0.27 & 0.26 & 0.29 & 0.36 & 0.34 & \\
\hline 12 & 0.30 & 0.24 & 0.40 & 0.28 & 0.28 & 0.30 & 0.37 & 0.36 & \\
\hline 14 & 0.32 & 0.25 & 0.40 & 0.29 & 0.29 & 0.31 & 0.37 & 0.37 & \\
\hline 30 & 0.32 & 0.25 & 0.41 & 0.29 & 0.30 & 0.32 & 0.38 & 0.38 & \\
\hline 18 & 0.33 & 0.26 & 0.42 & 0.30 & 0.31 & 0.32 & 0.39 & 0.38 & \\
\hline 20 & 0.34 & 0.26 & 0.42 & 0.30 & 0.32 & 0.33 & 0.39 & 0.39 & \\
\hline 0 & -1.16 & 0.71 & -0.35 & $\begin{array}{r}\mu m 01 \\
-1 \quad 32\end{array}$ & $\begin{array}{c}\mathrm{P} / \mathrm{EMS} \cdot \mathrm{h} \\
-175\end{array}$ & 073 & $\begin{array}{lll}-0 & 32\end{array}$ & -329 & \\
\hline 2 & 0.55 & 0.49 & 1.37 & 0.80 & 0.23 & 0.76 & 1 no & 07 & \\
\hline 4 & 1.14 & 0.89 & 1.89 & 1.27 & 1.00 & 1.33 & 1.53 & 1.27 & \\
\hline 6 & 1.43 & 1.08 & 2.14 & 1.47 & 1.41 & 1.62 & 1.75 & 1.62 & \\
\hline 8 & 1.61 & 1.20 & 2.28 & 1.59 & 1.66 & 1.81 & 1.88 & 1.81 & \\
\hline 10 & 1.73 & 1.28 & 2.38 & 1.66 & 1.84 & 1.93 & 1.96 & 1.94 & \\
\hline 12 & 1.81 & 1.34 & 2.44 & 1.71 & 1.96 & 2.02 & 2.02 & 2.02 & \\
\hline 14 & 1.87 & 1.38 & 2.49 & 1.75 & 2.06 & 2.09 & 2.06 & 2.09 & \\
\hline 16 & 1.92 & 1.41 & 2.53 & 1.78 & 2.13 & 2.14 & 2.10 & 2.13 & \\
\hline 18 & 1.96 & 1.44 & 2.56 & 1.80 & 2.19 & 2.18 & 2.13 & 2.17 & \\
\hline 20 & 2.00 & 1.46 & 2.59 & 1.82 & 2.24 & 2.22 & 2.15 & 2.20 & \\
\hline & & & & $\mu \mathrm{mol}$ & $\mathrm{P} / \mathrm{p}$ lanta & $h$ & & & \\
\hline 0 & -1.93 & -1.76 & -0.78 & -2.41 & -2.42 & -1.41 & -0.80 & -4.48 & \\
\hline 2 & 0.92 & 1.20 & 3.05 & 1.46 & 0.32 & 1.46 & 2.78 & 0.64 & \\
\hline 4 & 1.89 & 2.17 & 4.20 & 2.32 & 1.39 & 2.54 & 3.89 & 1.73 & \\
\hline 6 & 2.37 & 2.66 & 4.74 & 2.70 & 1.95 & 3.10 & 4.43 & 2.21 & \\
\hline 8 & 2.67 & 2.95 & 5.07 & 2.91 & 2.30 & 3.45 & 4.75 & 2.47 & \\
\hline 10 & 2.86 & 3.14 & 5.28 & 3.05 & 2.54 & 3.88 & 4.97 & 2.64 & \\
\hline 12 & 3.00 & 3.28 & 5.43 & 3.14 & 2.72 & 3.85 & 5.12 & 2.76 & \\
\hline 14 & 3.11 & 3.38 & 5.54 & 3.21 & 2.85 & 3.98 & 5.23 & 2.85 & \\
\hline 16 & 3.19 & 3.46 & 5.63 & 3.27 & 2.95 & 4.08 & 5.32 & 2.91 & - \\
\hline 18 & 3.26 & 3.53 & 5.70 & 3.31 & 3.04 & 4.16 & 5.39 & 2.96 & \\
\hline 20 & 3.31 & 3.58 & 5.75 & 3.34 & 3.11 & 4.23 & 5.45 & 3.01 & \\
\hline
\end{tabular}




\section{Carioca}

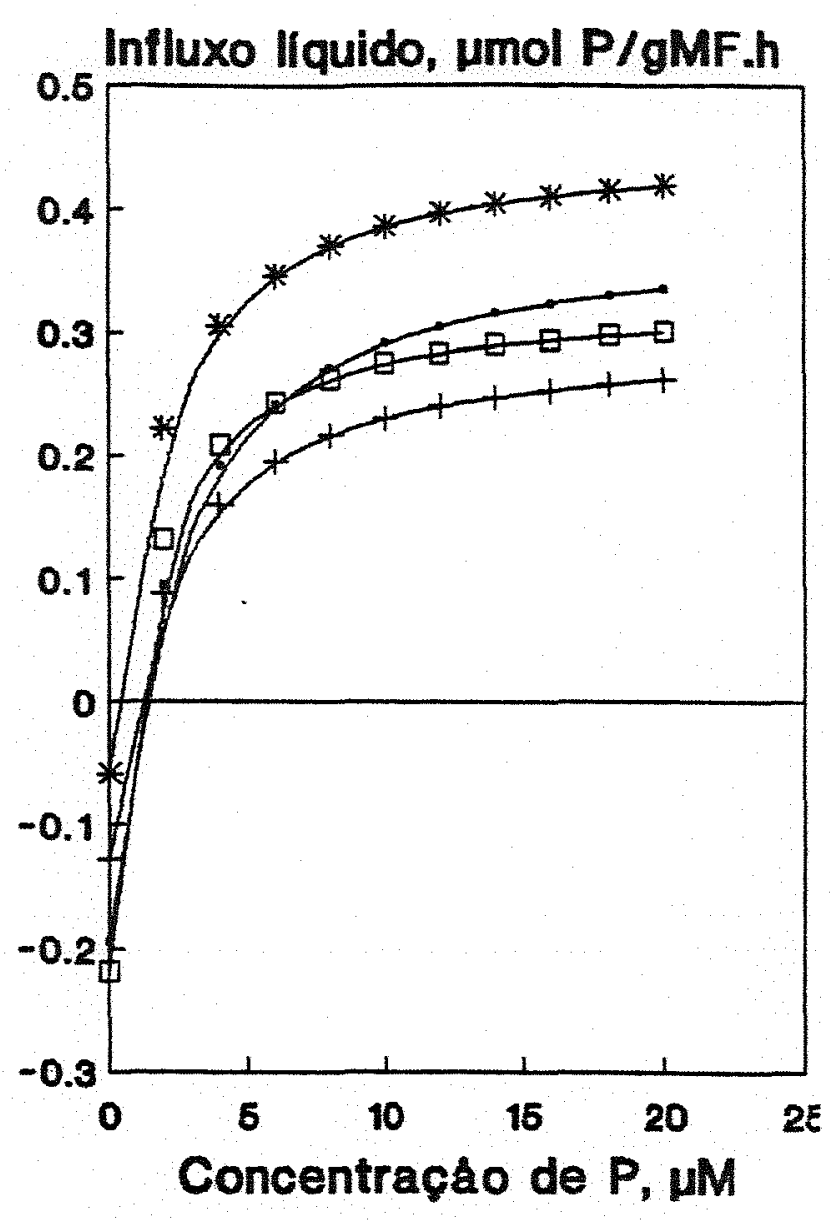

Negro Argel

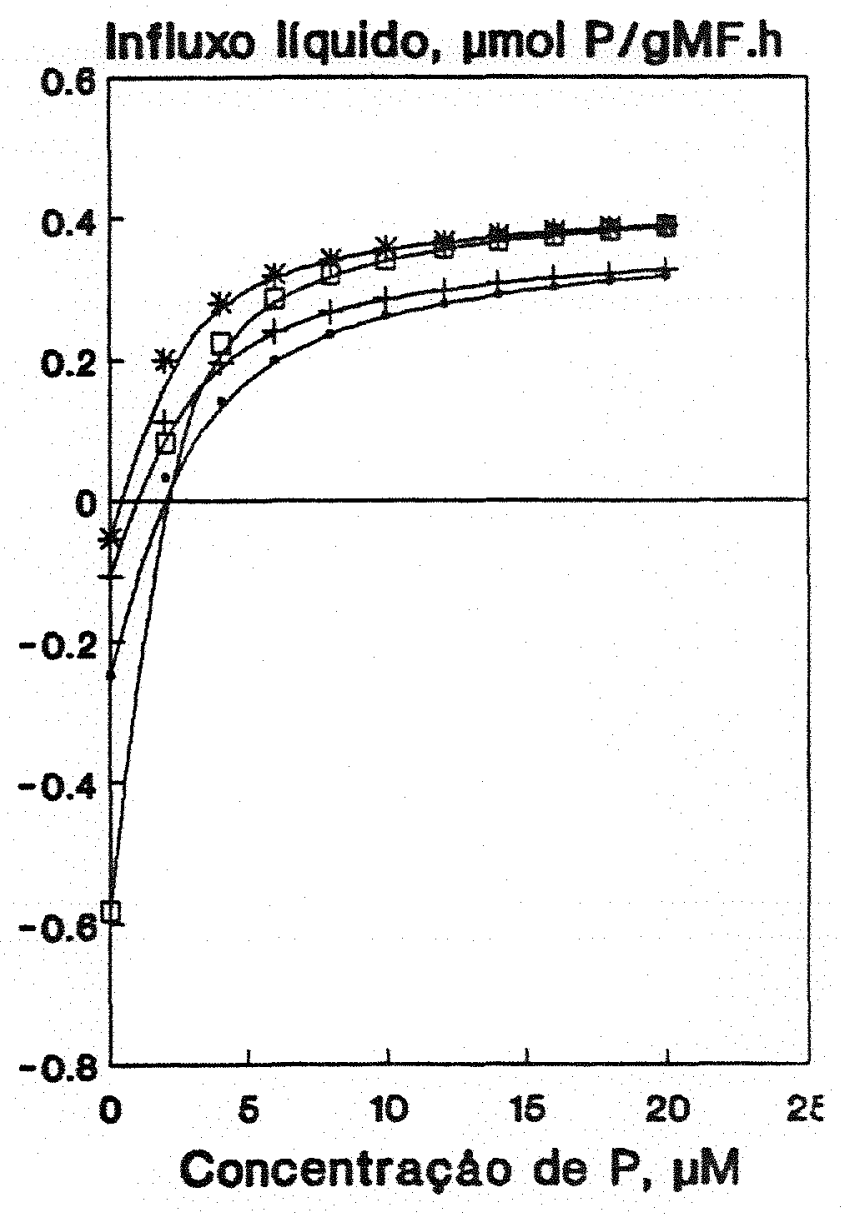

$-T-P_{1}+\mathrm{T}-\mathrm{P}_{2} \rightarrow \mathrm{GE} \rightarrow \mathrm{SH}$

Eigura 6. Influxo liquido de $P$ por unidade de peso de matéria fresca de raiz, em funço da concentraçáo de P na solugão, em duas cultivares de feijăo ( Carioca e Negro Argel), na ausência ( $\mathrm{T}-\mathrm{P}_{1-}$ Testemunha com $0.3 \mathrm{ppm} P ; \mathrm{T}-\mathrm{Pz}-$ Testemunha com $3.0 \mathrm{ppm}$ P) e presenca de micorriza (GE- Glonus etunicatua; SH Scutellospora heterogama). Curvas traçadas segundo a equaçáo de Michaelis - Menten. 


\section{Carioca}

\section{Negro Argel}

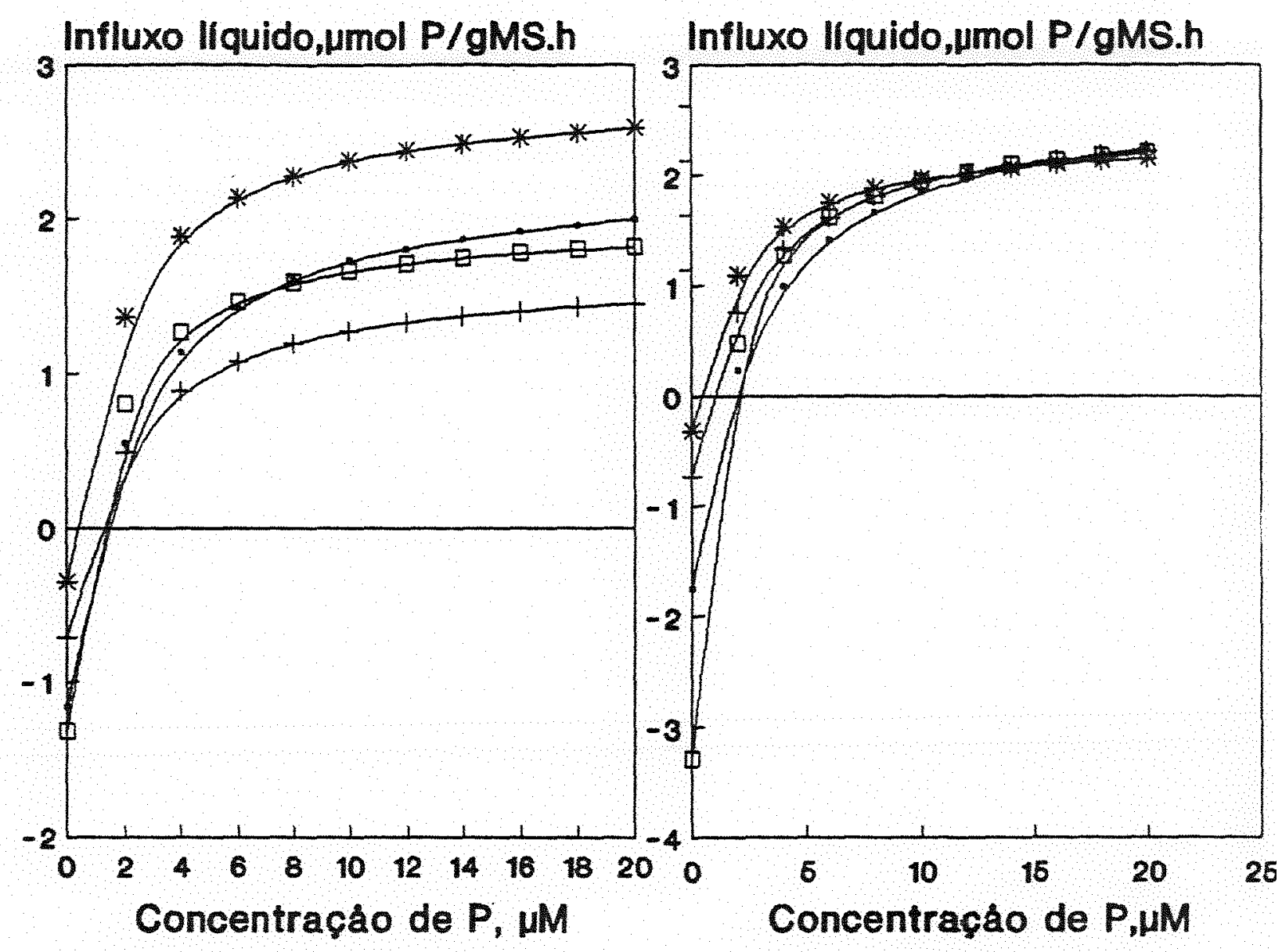

$\rightarrow T-P 1+T P 2 \rightarrow G E-8 H$

Figura 7. Influxo líquido de $P$ por unidade de peso do matéria seca de raiz, en funçáo da concentracão de $P$ na solucão, en duas cultivares de feljăo (Carioca e Negro Argel), na ausência ( $\mathrm{T}-\mathrm{F}_{1}$ Testemunha com 0.3 ppm $\mathrm{P} ; \mathrm{T}-\mathrm{P}_{2}-$ Testemunha com 3.0 ppm P) e presenca de micorriza (GE-Glonus etunicatun; SH-Scutellaspora heterogana) Curvas tracadas de acordo com a equacăo de MichaelisMenten. 


\section{Carioca}

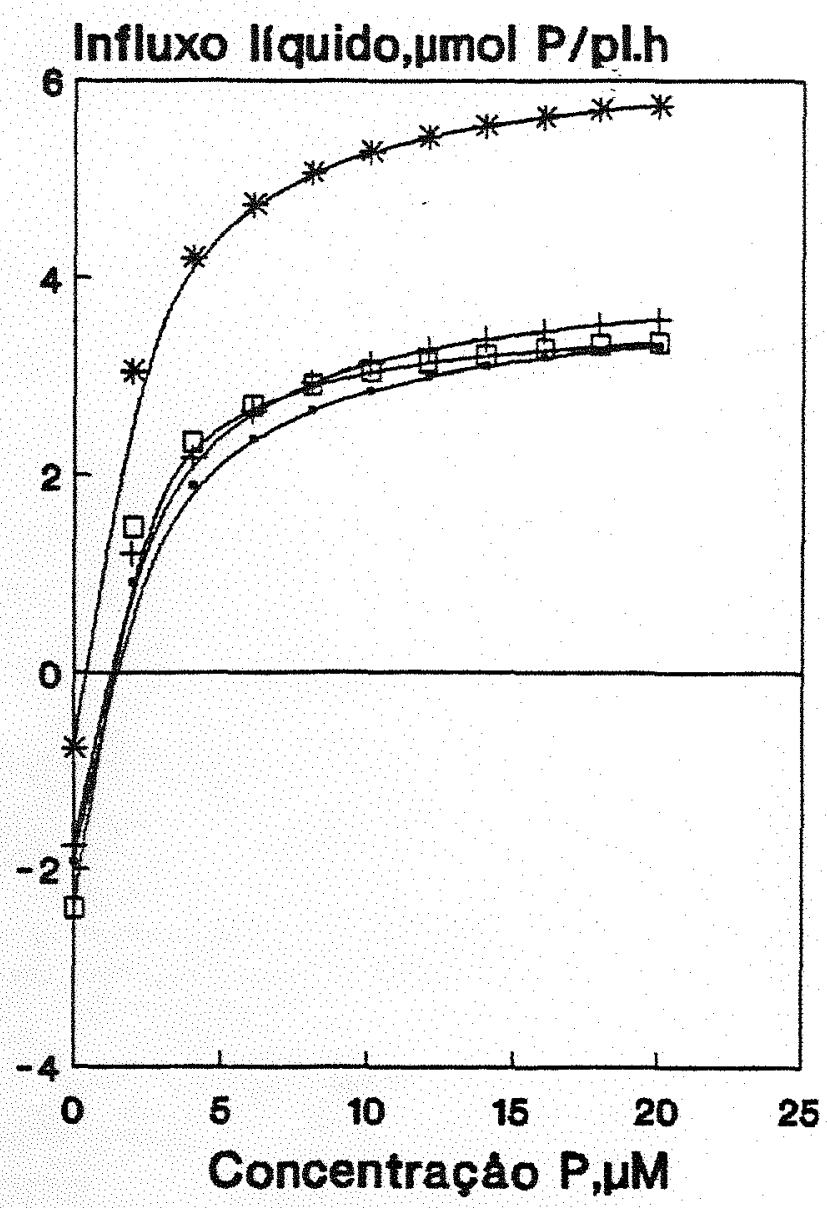

Negro Argel

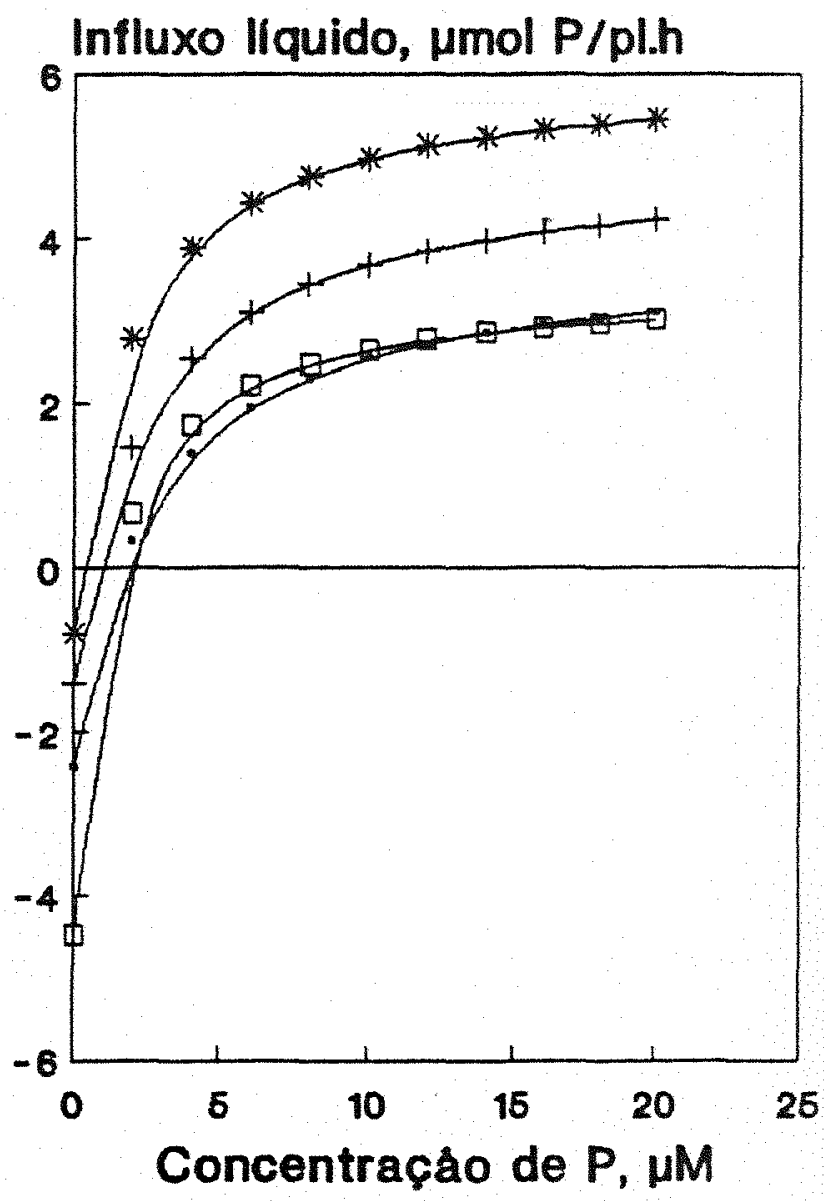

$\rightarrow T-P 1+T-P 2-$ GE $\square$ SH

Figura 8. Influxo liquido de $\mathrm{P}$ por planta em funça da concentragão de $P$ na soluçăo, en duas cultivares de feijão (Carioca e Negro Argel) na ausência ( $\mathrm{T}-\mathrm{P}_{1}-$ Testemunha com $0.3 \mathrm{ppm} \mathrm{P} ; \mathrm{T}-\mathrm{P}_{2}-$ Testemunha com 3.0 ppm P) e presenga de micorriza (GEGlomus etunicatum; SH- Scutellospora heterogama). Curvas traçadas segundo a equaçäo de Michaelis Menten. 
$\mathrm{Na}$ cultivar Carioca, Glomus promoveu um influxo 45\% superior ab promovido por Scutellospora, ao passo que na Negro Argel, os endófitos praticamente nao diferiran.

Considerando-se o influxo por unidade de peso de matéria seca de raiz (Figura 7), constatou-se que na Carioca, Glomus superou $\mathrm{T}-\mathrm{P}_{1}$ em $51 \%$, enquanto Scutellospora não diferiu da testemunha; o primeiro endófito superou $\mathrm{T}-\mathrm{P}_{2}$ em $96 \%$ e Scutellospora en $46 \%$, sendo que este fungo também causou um aumento no influxo de $34 \%$, em relaçăo a $\mathrm{T}-\mathrm{Pz}$. Já na Negro Argel, praticamente nao houve diferenga entre os tratamentos.

Quanto ao influxo por planta, que considera o peon total do sistema radicular (Figura 8 e Tabela 8), constatou-se que $G$. etunicatum aumentou o influxo em $100 \%$ na Carioca e Negro argel, comparando com T-P1. Este endófito ainda gerou incrementos de $78 \%$ na Carioca e $41 \%$ na Negro Argel, quando comparado a T-P2. Com $S$. heterogana, o influxo foi $14 \%$ superior a $\mathrm{T}-\mathrm{P}_{1}$ em ambas as cultivares, entretanto, foi $32 \%$ inferior a T-Pz na Negro Argel. Em ambas cultivares, Glomus superou Scutellospora em $75 \%$ e $90 \%$, respectivamente na Carioca e Negro Argel. As plantas testemunhas que receberam maior dose de $\mathrm{P}\left(\mathrm{T}-\mathrm{P}_{2}\right)$ apresentaram um influxo de $\mathrm{P}$ por planta superior àquelas com menor dose de $\mathrm{P}\left(\mathrm{T}-\mathrm{P}_{1}\right)$, sendo este aumento, em torno de $48 \%$ na Negro Argel e $12 \%$ na Carioca. Entretanto, as plantas $\mathrm{T}-\mathrm{P}_{2}$ tiveram um influxo por unidade de peso de matéria fresca e seca de raiz $24 \%$ inferior a $\mathrm{T}-\mathrm{P}_{1}$ na Carioca, mas $7 \%$ superior na Negro Argel.

0 apêndice 3 mostra o valor de $F$ da análise da variância das variáveis relacionadas ao crescimento e nutriçăo mineral das plantas. Algumas delas não tiveram interaço significativa, somente efeito de fator isolado.

As raizes das plantas, quando na presença de G. etunicatum, apresentaram-se significativamente mais colonizadas do que com $S$. heterogama, não havendo, entretanto, diferença entre as cultivares (Tabela 9). 
Tabela 9. Peso da matéria seca da parte aérea (PMSPA), peao da matéria seca de nódulos (PMSNOD) e porcentagem de infeção na raiz de duas cultivares de feijao (Carioca e Negro Argel), na ausencia ( $\mathrm{T}-\mathrm{P}_{1}-$ Testemunha com 0.3 ppm F;T-Pz-Testemunha com 3.0 ppm P) e presenca de micorriza (GE- Glonus etunicatum; SH- Scutellospora heterogama). (Mèdias de seis repetiçes ${ }^{1}$

\begin{tabular}{|c|c|c|c|c|}
\hline CULTIVAR/EUMGO & $T-E_{1}$ & $\mathrm{~T}-\mathrm{E} z$ & $G R$ & SH \\
\hline \multicolumn{5}{|c|}{ PMSPA (E) } \\
\hline CARIOCA & $1.42 \mathrm{cA}$ & $2.52 \mathrm{aB}$ & $2.48 \mathrm{aA}$ & $1.98 \mathrm{bA}$ \\
\hline NEGRO ARGEL & $1.25 \mathrm{cA}$ & $3.00 \mathrm{aA}$ & $2.72 \mathrm{aA}$ & $1.93 \mathrm{bA}$ \\
\hline \multicolumn{5}{|c|}{ PMSNOD (mg) } \\
\hline CARIOCA & $12.1 \mathrm{cA}$ & $87.9 \mathrm{aA}$ & $56.9 \mathrm{bA}$ & $17.5 \mathrm{cA}$ \\
\hline NEGRO ARGEL & $17.2 \mathrm{cA}$ & $76.4 \mathrm{aB}$ & $50.0 \mathrm{bB}$ & $14.0 \mathrm{cA}$ \\
\hline \multicolumn{5}{|c|}{ INEECÇAO RADICULAR (\%) } \\
\hline CARIOCA & 0.0 & 0.0 & $59.2^{*}$ & 35.2 \\
\hline NEGRO ARGEL & 0.0 & 0.0 & $61.8^{*}$ & 38.0 \\
\hline
\end{tabular}

1/Médias seguidas da mesma letra năo diferem entre si pelo teste de Tukey a $5 \%$. Letra minúscula refere-se à comparaçăo na linha, enquanto maiúscula, na coluna.

* - Teste de Tukey significativo a $5 \%$ para o fator fungo. 
Em ambas as cultivares, o efeito de S. heterogama no peso da matéria seca da parte aérea (PMSPA) $n$ ão diferiu de $T-P_{1}$, os quais foram superados significativamente por $\mathrm{T}-\mathrm{P}_{2}$ e $G$. etunicatum, que por sua vez nåo diferiram entre si (Tabela 9). Em relaça a T-P1, este último endófito aumentou o PMSPA em $75 \%$ na Carioca e $118 \%$ na Negro Argel. O maior peso de matéria seca dos nódulos (PMSnod) foi obtido nas plantas de $\mathrm{T}-\mathrm{P}_{2}$, que diferiu significativamente de todos os demais tratamentos, superando os endófitos em 55\%, em ambas as cultivares. G. etunicatum apresentou-se significativamente diferente de $S$. heterogama e T-PI, incrementando a nodulaça em $370 \%$ na Carioca e $180 \%$ na Negro Argel, em relação à testemunha.

De maneira geral, as cultivares diferiram entre si, ou seja Carioca superou Negro Argel, quanto aos teores de $\mathrm{N}, \mathrm{Ca}$ e $\mathrm{Mg}$ (Tabela 10), $\mathrm{P}$ e $\mathrm{K}$ (Apêndice 3), principalmente em $\mathrm{T}-\mathrm{P} z$ e quando colonizadas por Glomus. Com os teores de $\mathrm{N}, \mathrm{K}$ e $\mathrm{Ca}$ na parte aérea parece ter ocorrido efeito de diluiçăo, pois as plantas de T-P1 mostraram os maiores teores. Na simbiose formada com G.etunicatum, o teor de $\mathrm{P}$ náo diferiu de $\mathrm{T}-\mathrm{P}_{2}$, mas foi significativamente maior que naquelas com $S$. heterogana e T-P 1 , enquanto o teor de $\mathrm{Mg}$ diferiu estatisticamente de $\mathrm{T}-\mathrm{P}_{2}, \mathrm{~T}-\mathrm{P}_{1}$ e do fungo S. heterogama, na cv Carioca.

Quanto à quantidade acumulada de macronutrientes na parte aérea (Tabela 10, Apêndice 3) constatou-se que as plantas de $T-P_{1}$ acumularam significativamente menos nutrientes que nos demais tratamentos. De modo geral, as micorrizas com $G$. etunicatum não diferiram das plantas da T-Pz, superando, entretanto, aquelas formadas com S.heterogana, na maioria das variáveis. Assim, a simbiose Glomus-Carioca, em relação a T-P1, teve um incremento de $26 \%, 126 \%, 49 \%, 56 \%$, e $156 \%$, enquanto Glouus Negro Argel apresentou $80 \%, 178 \%, 60 \%, 48 \%$ e $146 \%$ de aumento, no acúmulo de $\mathrm{N}, \mathrm{P}, \mathrm{K}, \mathrm{Ca}$ e $\mathrm{Mg}$, respectivamente. 
Tabela 10. Teor e quantidade acumulada de $\mathrm{N}, \mathrm{P}, \mathrm{K}, \mathrm{Ca}$ e $\mathrm{Mg}$ na parte aérea de duas cultivares de feijăo (Carioca e Negro Argel) na ausência (T-P1Testemunha com 0.3 ppm $\mathrm{P} ; \mathrm{T}-\mathrm{P}_{2}-\mathrm{Testemunha}$ com 3.0 ppm P) e presença de micorriza (GE- Glomus etunicatud; SH- Scutellospora heterogana). (Médias de seis repetiçனes) $1 /$

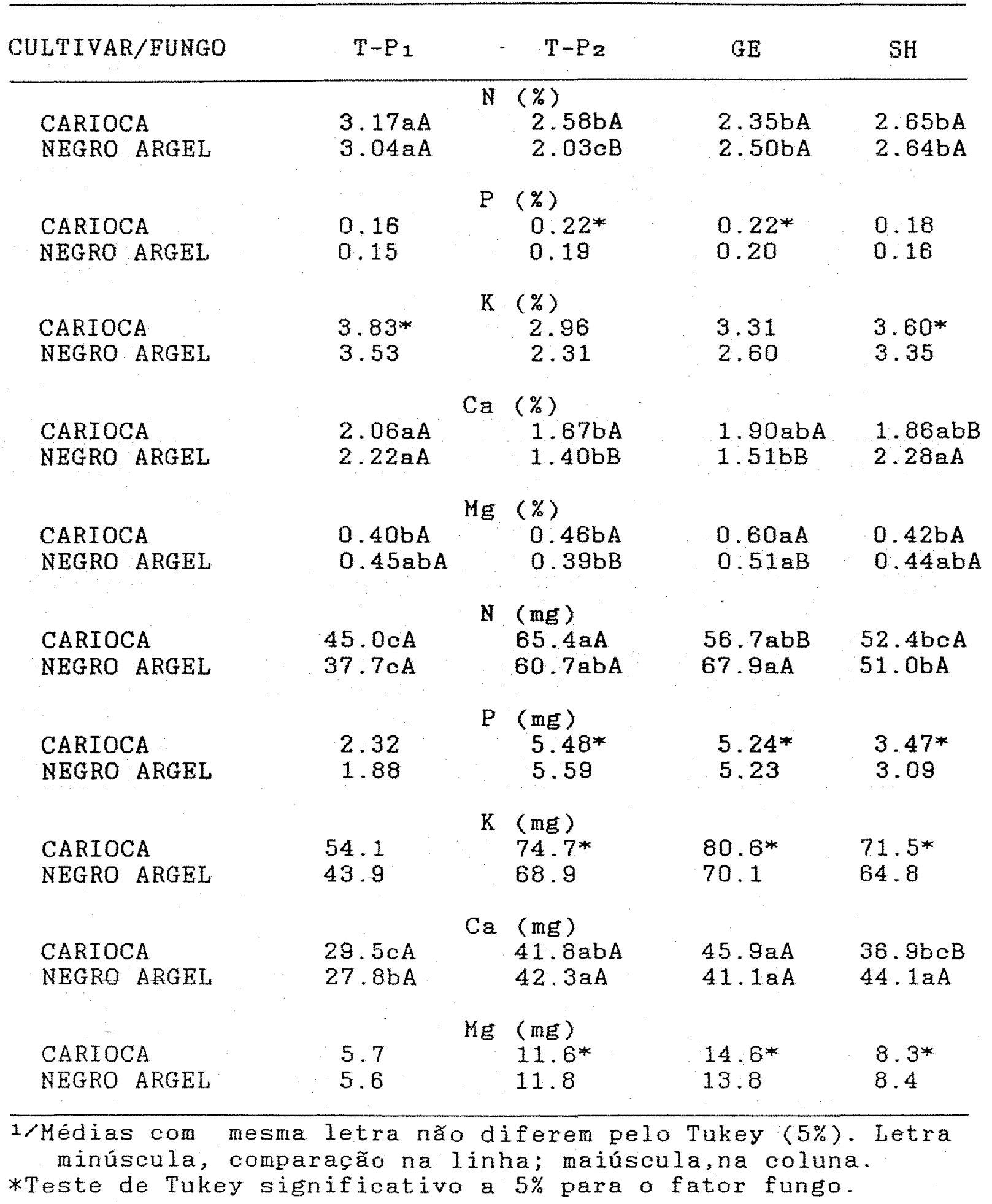


As cultivares praticamente não diferiram quanto ao acúmulo de macronutrientes na parte aérea (Apêndice 3).

A resposta das plantas aos diferentes tratamentos, quanto à absorção de alguns micronutrientes, foi variável (Tabela 11). As plantas micorrizadas com S.heterogama apresentaram significativamente as menores concentraçóes de Mn na parte aérea, em média $66 \%$ e $39 \%$ menos na Carioca e Negro Argel, respectivamente, em relaço aos demais tratamentos. O teor de $\mathrm{Zn}$ diminuiu significativamente nas plantas micorrizadas e $\mathrm{T}-\mathrm{Pr}$ (em torno de $30 \%$ ), mas só na cultivar Negro Argel, enquanto que o $\mathrm{Cu}$ aumentou nas simbioses, principalmente nas formadas com Glomus, em ambas as cultivares, superando $\mathrm{T}-\mathrm{Pz}_{2}$ em $147 \%$ na Carioca e $81 \%$ na Negro Argel. Houve uma grande concentraça de Fe na parte aérea da Negro Argel colonizada por $S$. heterogama (em média $190 \%$ acima dos demais tratamentos). Nesta mesma simbiose, a quantidade de $F e$ acumulada diferiu significativamente dos demais tratamentos, cujo acúmulo relativo a $\mathrm{T}-\mathrm{P}_{1}$ foi de $332 \%$ a $\mathrm{T}-\mathrm{Pz}_{2}$, de $80 \%$. A quantidade acumulada de $\mathrm{Cu}$ foi estatisticamente maior nas simbioses formadas por $G$. etunicatum $(133 \%$ e $58 \%$ na Carioca e Negro Argel, respectivamente, em relaçăo a $\mathrm{T}-\mathrm{P}_{2}$ ), enquanto o $\mathrm{Zn}$ e $\mathrm{Mn}$ apresentaram-se significativamente maiores na presença de Glomus e em $\mathrm{T}-\mathrm{P}_{2}$, en ambas as cultivares. A quantidade de Mn na parte aérea da Carioca colonizada por Scutellospora diferiu significativamente dos demais tratamentos, sofrendo uma redução de $79 \%$ quando comparado ao Glomus. De modo geral, a simbiose Carioca-G. etunicatum apresentou maiores teores e quantidades acumuladas de micronutrientes do que a estabelecida pelo mesmo endófito na Negro Argel. 
Tabela 11. Teor e quantidade acumulada de $\mathrm{Fe}, \mathrm{Zn}, \mathrm{Cu}$ e $\mathrm{Mn}$ na parte aérea de duas cultivares de feijăo (Carioca e Negro Argel) na ausência ( $T-P_{1}$ : Testemunha com 0.3 ppmP;T-P $2:$ Testemunha com 3.0 ppmP) e presenca de micorriza (GE-Glomus etunicatum; SHScutellospora heterogama).(Médias de seis repeticões) 1

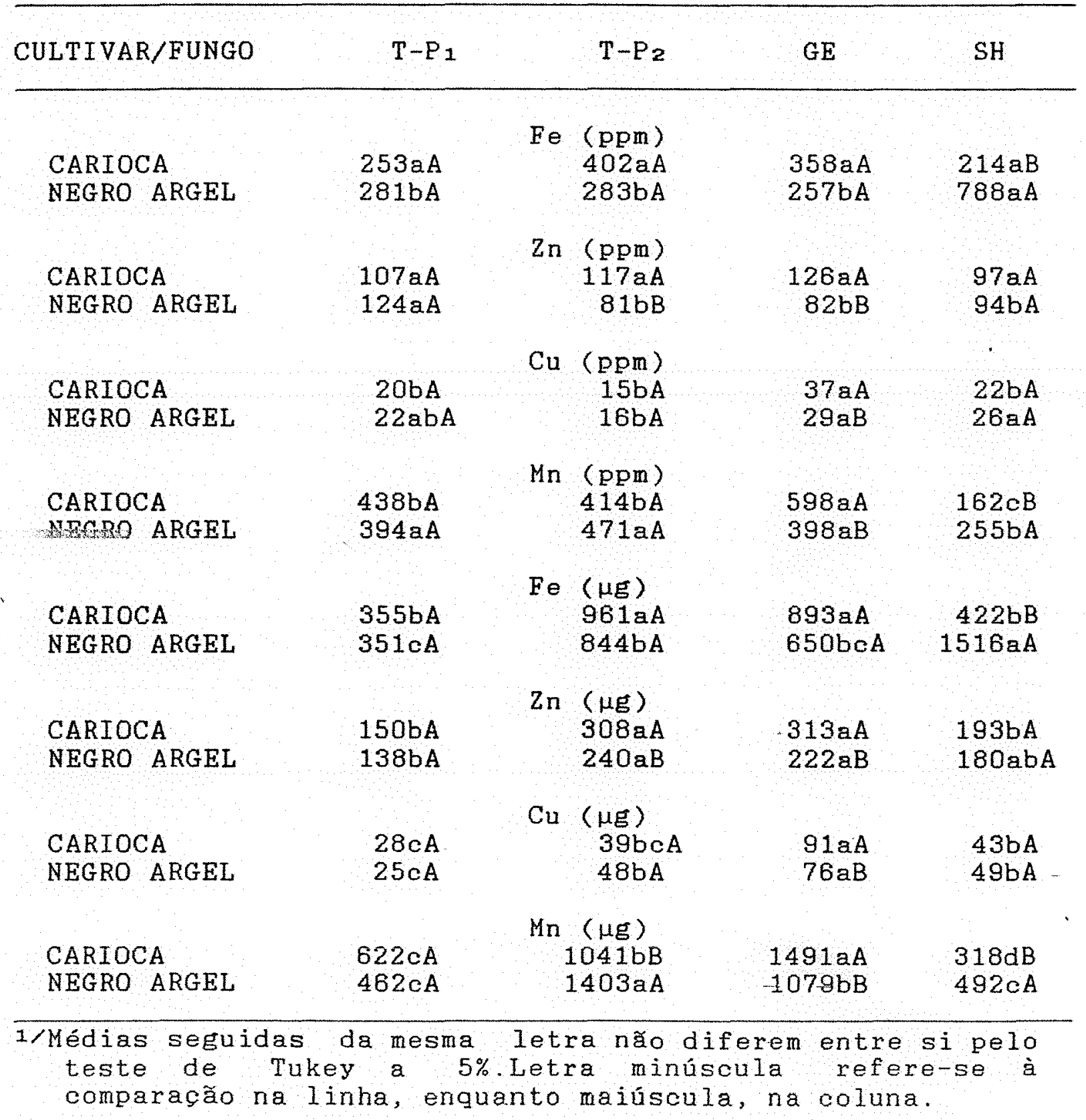




\section{3- EXPERIMENTO III}

A figura 9 mostra que a velocidade de exaustão do $P$ da solução foi pouco influenciada pela idade da planta; até a quarta hora de absorça, as plantas micorrizadas praticamente näo diferiram, mas a partir deste tempo, as mais velhas (50 DAS) esgotaram mais $P$ do que as mais jovens ( 35 DAS).

Os parâmetros cinéticos da absorça radicular de $P$, estimados através das equaçóes de ajuste (Apêndice 4), foram influenciados pela micorrizacá do feijoeiro e variaram com a época do ciclo da planta (Tabela 12). De modo geral, a $V_{\max }$ foi maior aos 35 dias após semeadura (DAS), diferindo em $100 \%$ da velocidade observada aos 50 DAS, quando as raizes estavam colonizadas por $G$. etunicatum. Considerando-se a $V_{m a x}$ de absorcão expressa por planta, constatou-se que não houve grande variação entre as épocas. As plantas micorrizadas apresentaram as maiores $V_{m a x}$, superando a testemunha com menor dose de $P$ adicionado ( $T_{1}$ ) em $80 \%$ e $29 \%$, e aquela com maior nivel de $P\left(T_{2}\right)$ em $64 \%$ e $29 \%$, respectivamente aos 35 e 50 DAS (velocidade expressa por unidade de raiz). As plantas da testemunha $T_{1}$ tiveram os menores valores de $\mathrm{V}_{\max }$ e de $\mathrm{T}_{2}$, valores intermediários.

A afinidade das raízes pelo $P$ foi maior, quando estas estavam colonizadas pelo G. etunicatum (Tabela 12), ou seja, os valores de $K_{m}$ das plantas micorrizadas foram $34 \%$ e $24 \%$, aos 35 DAS, e $23 \%$ e $40 \%$, aos 50 DAS, menores do que $\mathrm{T}_{1}$ e $\mathrm{T}_{2}$, respectivamente. $0 \mathrm{~K}_{\mathrm{m}}$ praticamente nao se alterou com a idade da planta. A $\mathrm{C}_{\mathrm{m}} \mathrm{n}$ diminuiu $22 \%$ em $\mathrm{T}_{1}$ e $79 \%$ nas plantas micorrizadas, aumentando, no entanto, $22 \%$ em $\mathrm{T} 2$, aos 50 DAS. Nesta mesma época, as plantas colonizadas por $G$. etunicatum exibiram uma $\mathrm{C}_{\mathrm{m} i n} 78 \%$ menor que as testemunhas. 


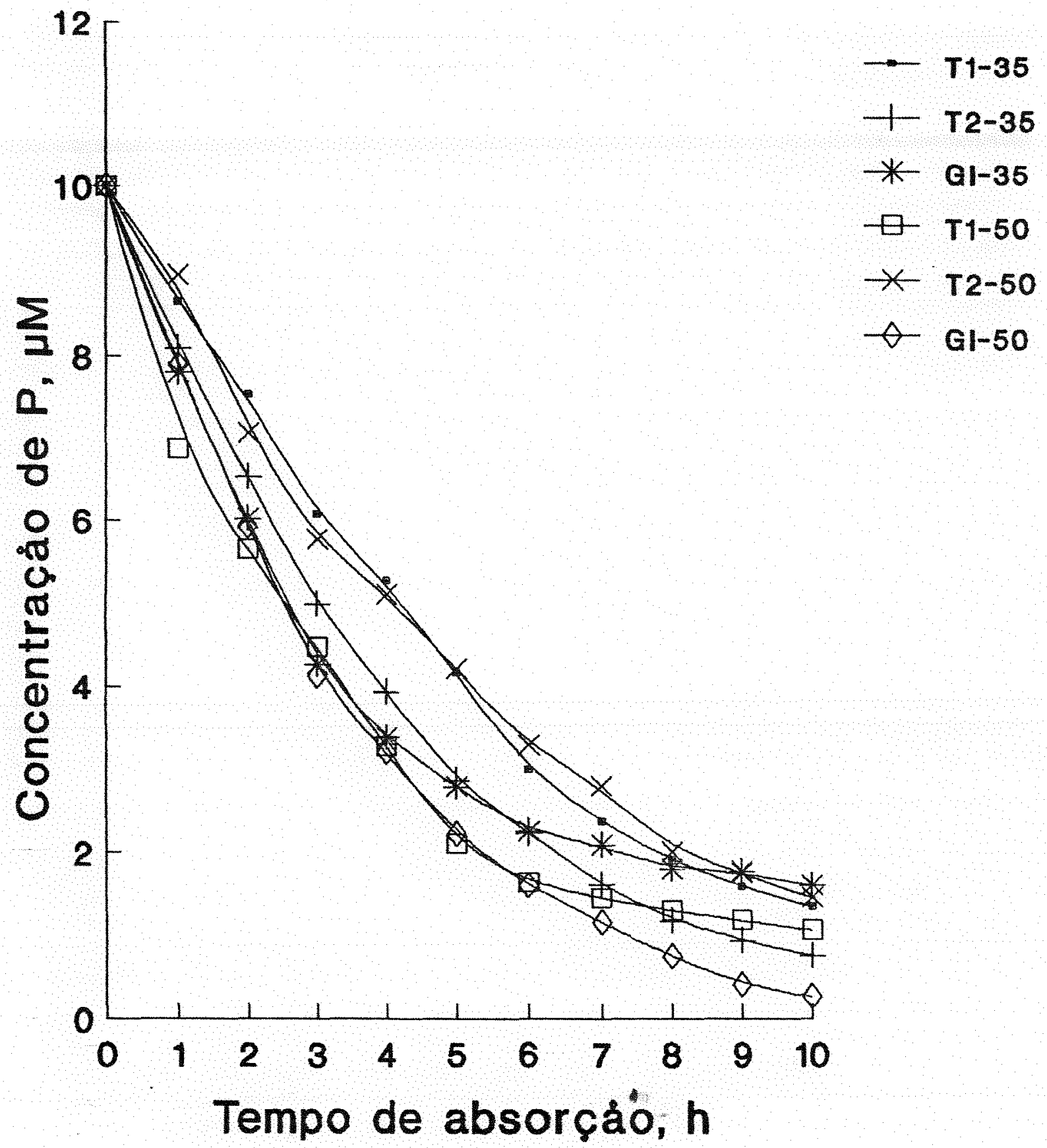

Figura 9 . Curva de exaustão de $P$ da solucão em funcão do tempo de absorcão, en feijoeiro não micorrizado ( $\mathrm{T}_{1}$ - Testemunha com 0.3 ppm $\mathrm{P} ; \mathrm{T}_{2}$ - Testemunha com 3.0 ppm P) e micorrizado (GE-Glomus etunicatum) en duas épocas do ciclo da cultura ( 35 e 50 dias após semeadura). Curvas tracadas segundo a equacăo de Miohaelis-Menten. 
Tabela 12. Parâmetros cinéticos ( $\left.V_{m a x}, K_{m}, C_{m}{ }_{m}\right)$ da absorçăo radicular de $P$ e peso da matéria freca da raiz (PMFR) de feijoeiro não micorrizado ( $T-P_{1}$ : Testemunha com $0.3 \mathrm{ppm} P ; \mathrm{T}-\mathrm{P}_{2}:$ Testemunha com 3.0 ppm $\mathrm{P}$ ) e micorrizado (GE- Glomus etunicatun) em duas épocas do ciclo da planta ( 35 e 50 dias após semeadura). (Médias de três repetições).

\begin{tabular}{|c|c|c|c|c|c|}
\hline \multirow{2}{*}{ TRATAMENTO. } & \multicolumn{2}{|c|}{$V_{\max }$} & \multirow{2}{*}{$\frac{\mathrm{K}_{\mathrm{m}}}{\mu \mathrm{M}}$} & \multirow{2}{*}{$\frac{C_{m \perp n}}{\mu M}$} & \multirow{2}{*}{$\frac{\text { PMFR }}{\mathrm{g}}$} \\
\hline & $\mu \mathrm{mol} / \mathrm{g} . \mathrm{h}$ & $\mu \mathrm{mol} / \mathrm{pl} \cdot \mathrm{h}$ & & & \\
\hline$T_{I}-35$ & 0.30 & 2.80 & 2.66 & 1.56 & 8.9 \\
\hline $\mathrm{T}_{2}-35$ & 0.33 & 3.87 & 2.29 & 0.86 & 11.7 \\
\hline $\mathrm{GE}-35$ & 0.54 & 4.39 & 1.75 & 1.33 & 8.1 \\
\hline $\mathrm{T}_{1}-50$ & 0.21 & 2.98 & 2.24 & 1.22 & 14.0 \\
\hline $\mathrm{T}_{2}-50$ & 0.21 & 3.34 & 2.84 & 1.26 & 15.7 \\
\hline$G E-50$ & 0.27 & 4.48 & 1.72 & 0.28 & 16.5 \\
\hline
\end{tabular}

A micorrizacão do feijoeiro promoveu maior influxo e influxo líquido de $P$ por unidade de peso de matéria fresca de raiz (Tabelas 13 e 14, Figuras 10 e 11)). Aos 35 DAS, o influxo nas plantas micorrizadas foi $91 \%$ e $73 \%$ e 0 influxo líquido $110 \%$ e $68 \%$ superior a $\mathrm{T}_{1}$ e $\mathrm{T}_{2}$, respectivamente. Aos 50 DAS, o influxo da planta micorrizada superou $\mathrm{T}_{2}$ em $30 \%$, não diferindo, entretanto, de $\mathrm{T}_{1} .0$ influxo $\mathrm{e}$ influxo liquido de $\mathrm{P}$ pelas plantas micorrizadas foi, respectivamente, $123 \%$ e $110 \%$ maior aos 35 DAS do que aos 50 DAS. 
Tabela 13. Influxo de $P$ por unidade de peso de materia fresca de raiz e por planta, em função da concentração de $P$ na solução, em feijoeiro não micorrizado ( $\mathrm{T}_{1}$ - Testemunha com $0.3 \mathrm{ppm} \mathrm{P}$; $\mathrm{T}_{2}-$ Testemunha com $3.0 \mathrm{ppm}$ P) e micorrizado (GEGlomus etunicatum) em duas épocas do ciclo da cultura ( 35 e 50 dias após semeadura).1\%

\begin{tabular}{|c|c|c|c|c|c|c|}
\hline Cone.P & $T_{1}-35$ & $\mathrm{~T}_{2}-35$ & $\mathrm{GE}-35$ & $T_{1-50}$ & $T_{z}-50$ & $G E-50$ \\
\hline$\mu \mathrm{H}$ & \multicolumn{6}{|c|}{ Influxo $(\mu \mathrm{mol} \mathrm{P} / \mathrm{g} \cdot \mathrm{h})$} \\
\hline 0 & 0 & 0 & 0 & 0 & 0 & 0 \\
\hline 2 & 0.13 & 0.15 & 0.29 & 0.12 & 0.08 & 0.13 \\
\hline 4 & 0.19 & 0.21 & 0.38 & 0.17 & 0.12 & 0.17 \\
\hline 6 & 0.22 & 0.24 & 0.42 & 0.19 & 0.14 & 0.19 \\
\hline 8 & 0.23 & 0.26 & 0.44 & 0.20 & 0.15 & 0.20 \\
\hline 10 & 0.25 & 0.27 & 0.46 & 0.21 & 0.16 & 0.21 \\
\hline 12 & 0.25 & 0.28 & 0.47 & 0.22 & 0.17 & 0.21 \\
\hline 14 & 0.26 & 0.28 & 0.48 & 0.23 & 0.17 & 0.21 \\
\hline 16 & 0.27 & 0.29 & 0.49 & 0.23 & 0.18 & 0.22 \\
\hline 18 & 0.27 & 0.29 & 0.49 & 0.23 & 0.18 & 0.22 \\
\hline 20 & 0.27 & 0.30 & 0.50 & 0.23 & 0.18 & 0.22 \\
\hline
\end{tabular}

Influxo por planta ( $\mu$ mol P/pl.h)

$\begin{array}{lllllll}0 & 0 & 0 & 0 & 0 & 0 & 0 \\ 2 & 1.39 & 1.80 & 2.34 & 1.81 & 1.34 & 2.41 \\ 4 & 1.94 & 2.46 & 3.05 & 2.45 & 1.91 & 3.13 \\ 6 & 2.24 & 2.80 & 3.40 & 2.77 & 2.23 & 3.48 \\ 8 & 2.42 & 3.01 & 3.60 & 2.97 & 2.43 & 3.69 \\ 10 & 2.55 & 3.15 & 3.74 & 3.11 & 2.57 & 3.82 \\ 12 & 2.64 & 3.25 & 3.83 & 3.20 & 2.67 & 3.92 \\ 14 & 2.71 & 3.33 & 3.90 & 3.28 & 2.75 & 3.99 \\ 16 & 2.77 & 3.39 & 3.96 & 3.33 & 2.81 & 4.05 \\ 18 & 2.81 & 3.43 & 4.00 & 3.38 & 2.86 & 4.09 \\ 20 & 2.85 & 3.47 & 4.04 & 3.41 & 2.90 & 4.13\end{array}$

$1 / 0$ influxo, em cada concentraço de $\mathrm{P}$, foi calculado aplicando-se a equaça de Michaelis-menten: $I=V_{\max } \cdot \mathrm{C}$ $\mathrm{K}_{\mathrm{m}}+\mathrm{C}$ 
Tabela 14. Influxo líguido de $P$ por unidade de peso de matéria fresca de raiz e por planta, em funcão da concentraçăo de $P$ na solução, em feijoeiro não micorrizado ( $\mathrm{T}_{1}-$ Testemunha com $0.3 \mathrm{ppm} \mathrm{P} ; \mathrm{T}_{2}-$ Testemunha com $3.0 \mathrm{ppm}$ P) e micorrizado (GEGlomus etunicatun) em duas épocas do ciclo da cultura ( 35 e 50 dias após semeadura).1/

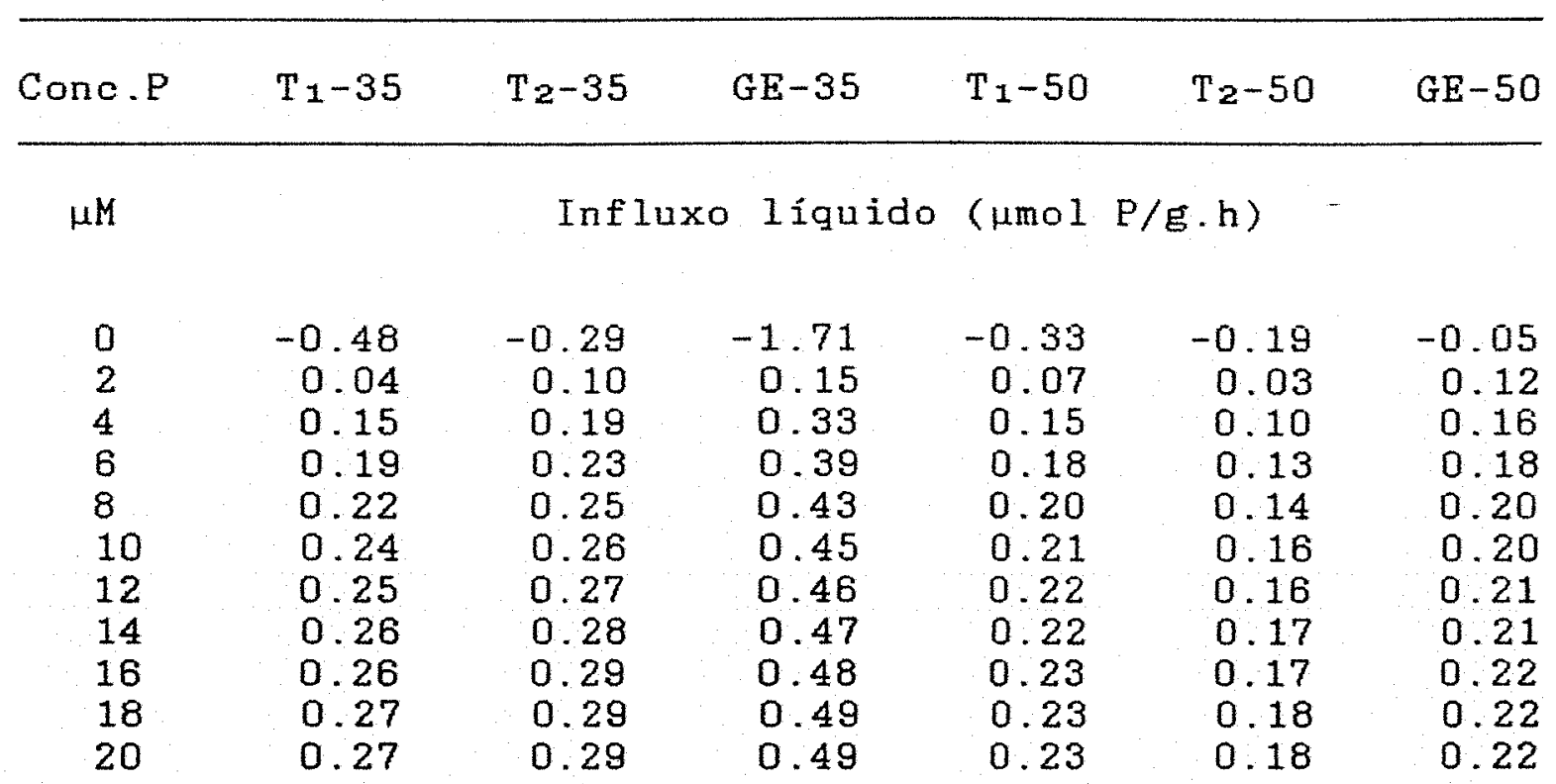

Influxo líquido por planta ( $\mathrm{mol} \mathrm{P} / \mathrm{pl} . \mathrm{h}$ )

$\begin{array}{rrrrrrr}0 & -4.95 & -3.33 & -13.91 & -4.71 & -3.00 & -0.87 \\ 2 & 0.41 & 1.13 & 1.22 & 0.99 & 0.54 & 2.24 \\ 4 & 1.53 & 2.18 & 2.65 & 2.12 & 1.55 & 3.06 \\ 6 & 2.01 & 2.65 & 3.20 & 2.60 & 2.02 & 3.45 \\ 8 & 2.28 & 2.91 & 3.48 & 2.86 & 2.29 & 3.66 \\ 10 & 2.45 & 3.08 & 3.65 & 3.03 & 2.48 & 3.81 \\ 12 & 2.57 & 3.20 & 3.77 & 3.15 & 2.60 & 3.91 \\ 14 & 2.66 & 3.29 & 3.86 & 3.23 & 2.70 & 3.98 \\ 16 & 2.73 & 3.36 & 3.92 & 3.30 & 2.77 & 4.04 \\ 18 & 2.78 & 3.41 & 3.97 & 3.35 & 2.83 & 4.08 \\ 20 & 2.82 & 3.45 & 4.01 & 3.39 & 2.88 & 4.12\end{array}$

1/Influxo líquido, en cada concentraça de P, foi calculado aplicando-se a equação de Michaelis-Menten. 


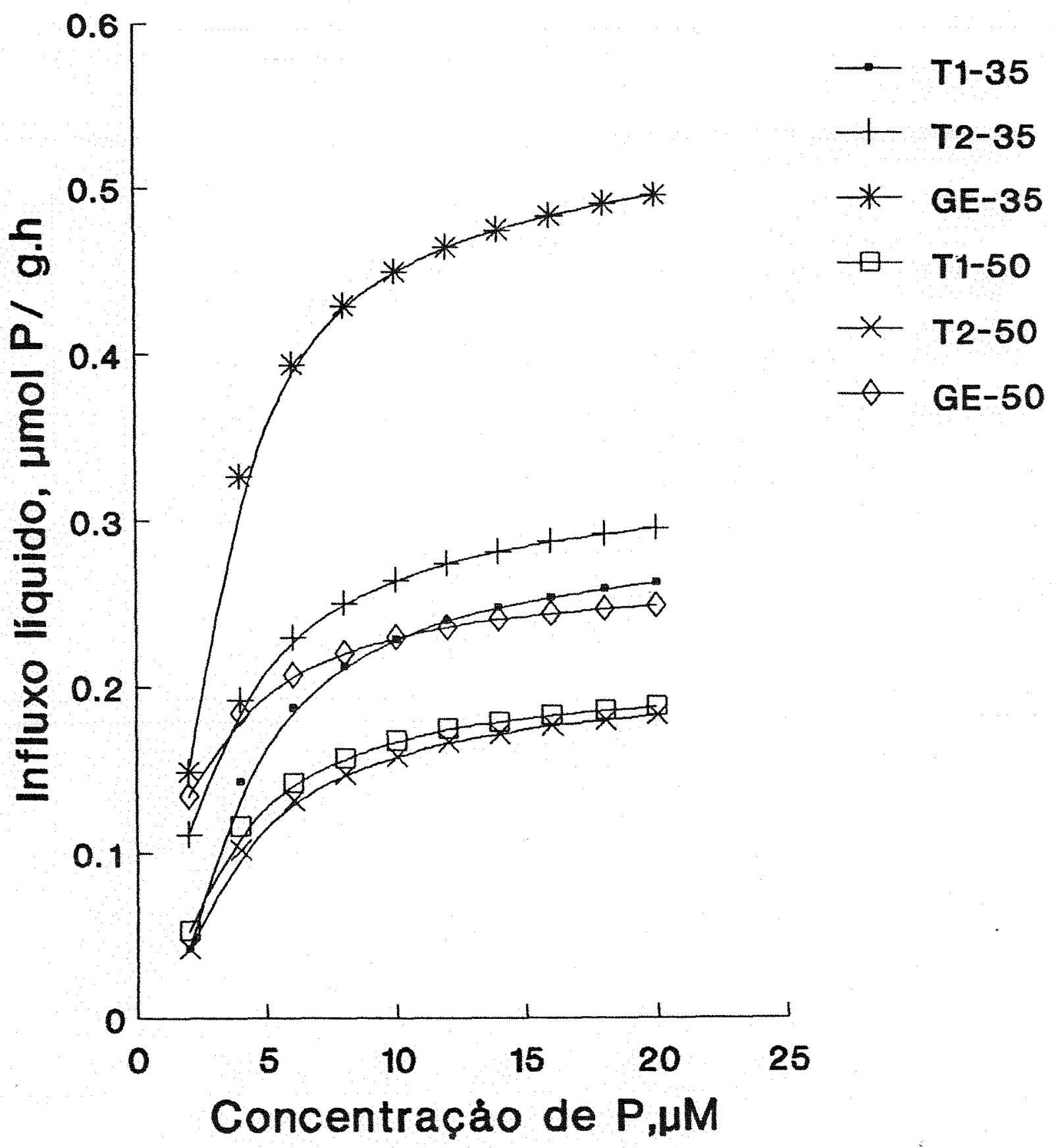

Eigura 10. Influxo líguido de $P$ por unidade de peso de matéria fresca de raiz, em funça da concentraçăo de $P$ na solucăo, em feijoeiro năo micorrizado ( $\mathrm{T} 1$ - Testemunha com 0.3 ppm P; T2-Testemunha com 3.0 ppm P) e micorrizado (GE-Glomus etunicatum) em duas épocas do ciclo da cultural 35 e 50 dias após semeadura). Curvas tracadas segundo a equação de Michaelis - Menten. 


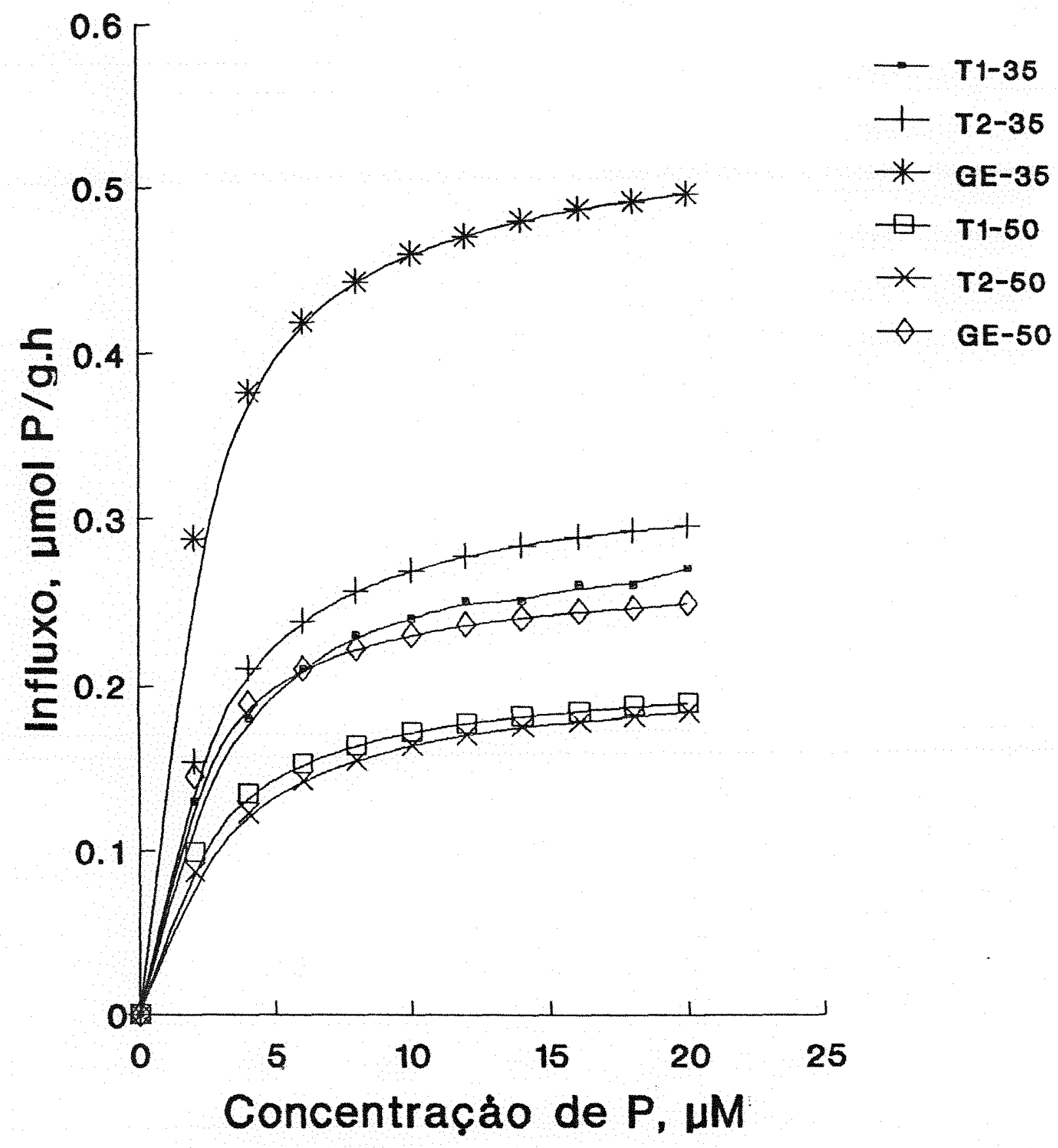

Figura 11. Influxo de $\mathrm{P}$ por unidade de peso de matéria fresca de raiz, em funça da concentraçao de $P$ na soluça, em feijoeiro não micorrizado ( $T_{1}-$ Testemunha com 0.3 ppm $P$; Tz-Testemunha com 3.0 ppm P) e micorrizado (GE- Glomus etunicatun) em duas épocas do ciclo da cultura ( 35 e 50 dias após semeadura). Curvas traçadas segundo a equaça de Michaelis - Menten. 
Já com relaçăo ao influxo e influxo liquido de $P$ por planta (Tabelas 13 e 14 , Figuras 12 e 13), verificou-se que as plantas micorrizadas, em ambas as épocas do ciclo, se destacaram das testemunhas, na diferindo de uma época para outra. A planta micorrizada, aos 35 DAS, superou $\mathrm{T}_{1}$, em média, $65 \%$ e $49 \%$, e $\mathrm{T}_{2}$, em $17 \%$ e $20 \%$, enquanto aos 50 DAS, esse incremento foi de $37 \%$ e $24 \%$, em relaça a $\mathrm{T}_{1}$ e $57 \%$ e $52 \%$ a $\mathrm{T}_{2}$, considerando-se, respectivamente, o influxo liquido e o influxo por planta.

Os valores de $F$ da análise da variância, segundo um esquema fatorial, das variáveis relacionadas ao crescimento e nutricăo mineral das plantas, encontram-se no Apêndice 5. As variáveis, que não apresentaram interacăo significativa, não tiveram o teste de médias (Tukey) mostrado, porque somente houve efeito isolado de algum dos fatores.

Só ocorreu efeito da micorrizaça sobre o crescimento das plantas aos 50 DAS (Tabela 15), sendo que o endófito aumentou significativamente a produçăo de matéria seca da parte aérea em $87 \%$, em relaçăo a $T_{1}$, mas não diferiu de Tz. A presenca do endófito gerou o maior aumento no crescimento da planta (240\%), comparando-se as duas épocas.

A porcentagem do comprimento de raiz infectada pelo fungo micorrizico (Tabela 15) foi $190 \%$ maior aos 50 DAS.

A tabela 16 mostra os teores e quantidades acumuladas de macronutrientes na parte aérea do feijoeiro. Os teores de $\mathrm{N}$ e $\mathrm{Ca}$ a a mostraram interação significativa (Apêndice 5), havendo somente efeito do fator época. Os teores de $\mathrm{N}$ e $\mathrm{K}$ apresentaram efeito de diluição na planta. 0 teor de $P$ nas plantas micorrizadas năo diferiu de $T_{1}$ e foi superado por $\mathrm{T} z$ aos 35 DAS; aos 50 DAS, as plantas micorrizadas tiveram significativamente 0 mesmo teor de $P$ que $\mathrm{T}_{2}$, mas superaram $\mathrm{T}_{1}$ em $50 \%$. O teor de $\mathrm{Ca}$ na diferiu entre os tratamentos, mas as plantas absorveram mais Ca aos 50 DAS. 


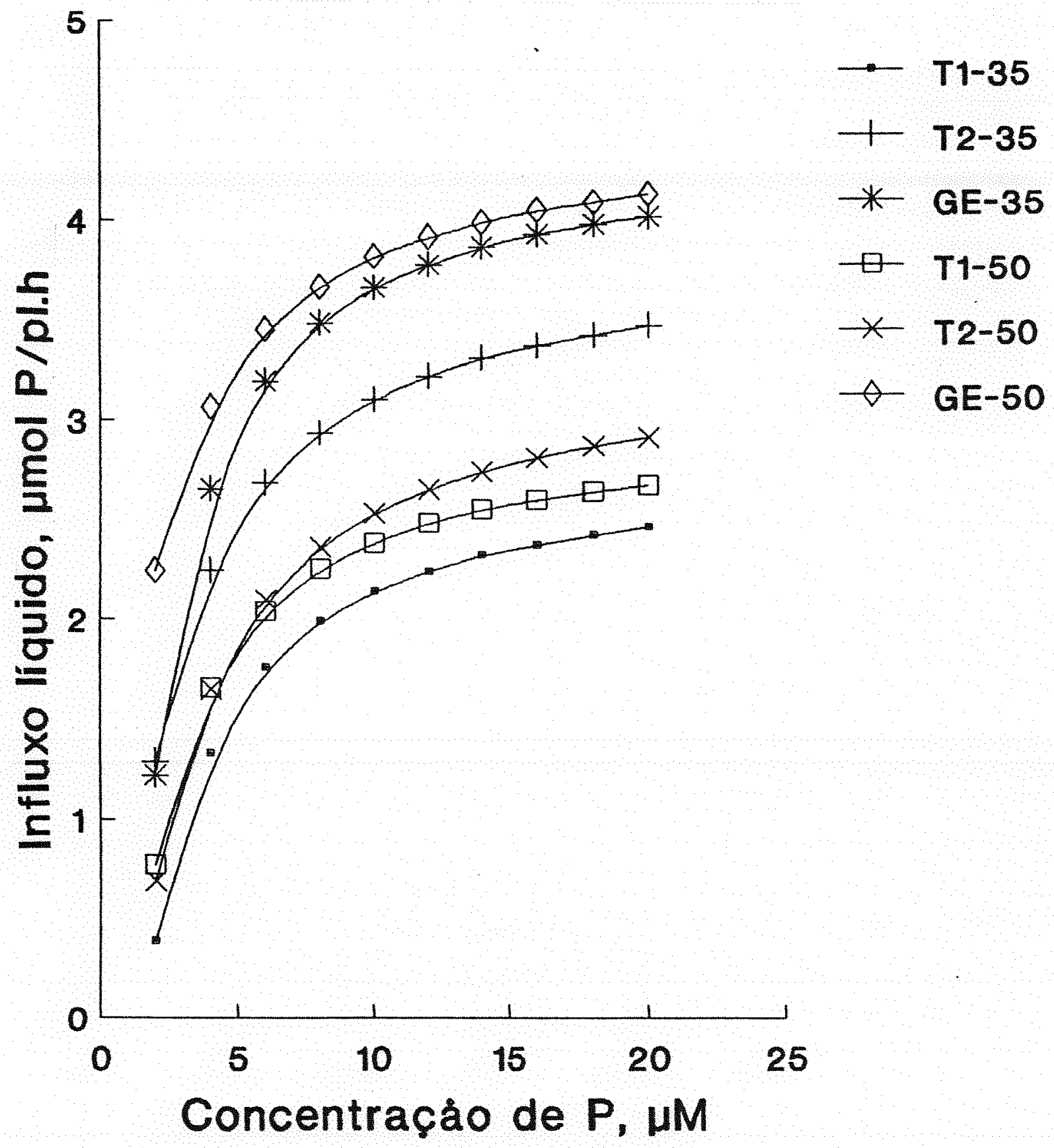

Figura 12. Influxo líguido de $P$ por planta, em funcro da concentração de $P$ na solução, em feijoeiro não mioorrizado ( $\mathrm{TI}_{1}$ - Testemunha com $0.3 \mathrm{ppm} \mathrm{P} ; \mathrm{Tz}-$ Testemunha com $3.0 \mathrm{ppm}$ P) e micorrizado (GEGlomus etunicatun) em duas épocas do ciclo da cultura ( 35 e 50 dias após semeadura). Curvas tracadas segundo a equaça de Michaelis -Menten. 


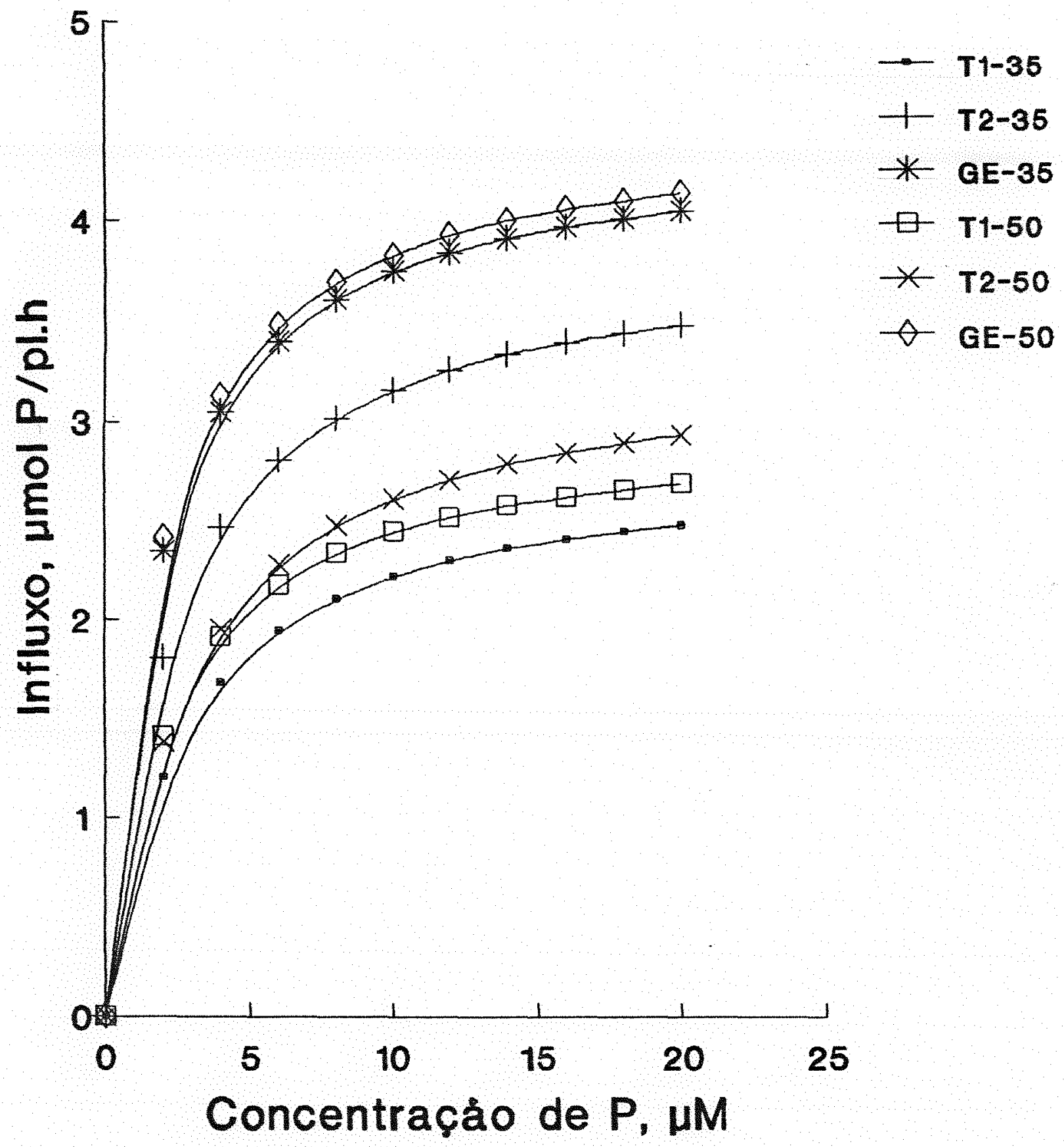

Figura 13. Influxo de $\mathrm{P}$ por planta, em funcão da concentracão de $P$ na solucăo, em feijoeiro não micorrizado ( $\mathrm{T}_{1}$ - Testemunha com 0.3 ppm $\mathrm{P} ; \mathrm{T}_{2}-\mathrm{Testemunha}$ com $3.0 \mathrm{ppm}$ P) e micorrizado (GE-Glomus etunicatum), em duas épocas do ciclo da cultura $(35$ e 50 dias após semeadura). Curvas tracadas segundo a equaca de Michaelis - Menten. 
Tabela 15. Peso da matéria seca da parte aérea (PMSPA) e porcentagem de infeç̧a na raiz de feijoeiro não micorrizado ( $\mathrm{T}_{1}-$ Testemunha com $0.3 \mathrm{ppm} \mathrm{P} ; \mathrm{T}_{2}-$ Testemunha com 3.0 ppm P) e micorrizado (GEGlomus etunicatum) em duas épocas do ciclo da cultura ( 35 e 50 dias após semeadura-DAS). (Médias de quatro repetiçós)'1/

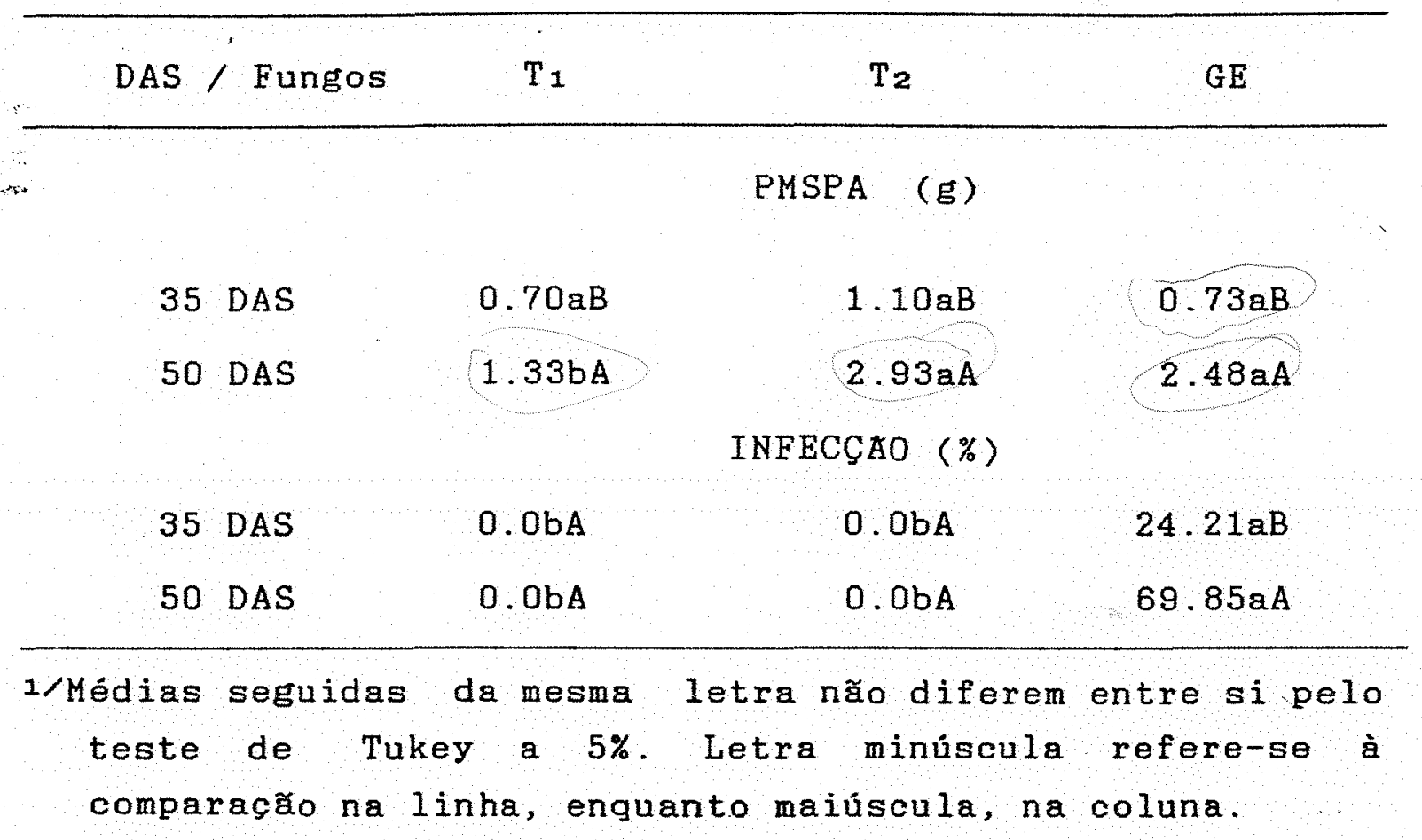

Por outro lado, aos 50 DAS, o $\mathrm{ME}$ foi aumentado em $86 \% \mathrm{nas}$ plantas micorrizadas, em relação a $T_{1}$, não diferindo, entretanto, de $\mathrm{T} z$. Comparando-se as épocas, observou-se que os teores de $\mathrm{P}, \mathrm{Ca}$ e $\mathrm{Mg}$ aumentaram, em média, $50 \%, 28 \%$ e . $90 \%$, respectivamente, aos 50 DAS, nas plantas micorrizadas. 
Tabela 16. Teor e quantidade acumulada de $\mathrm{N}, \mathrm{P}, \mathrm{K}, \mathrm{Ca}$ e $\mathrm{Mg}$ na parte aérea de feijoeiro năo micorrizado ( T $_{1}$ Testemunha com 3.0 ppm $\mathrm{P} ; \mathrm{T} 2-\mathrm{Testemunha}$ com 3.0 ppm P) e micorrizado ( $\mathrm{GE}$ - Glomus etunicatum) em duas épocas do ciclo da planta ( 35 e 50 dias após semeadura -DAS). (Médias de quatro repetiçós) 1 )

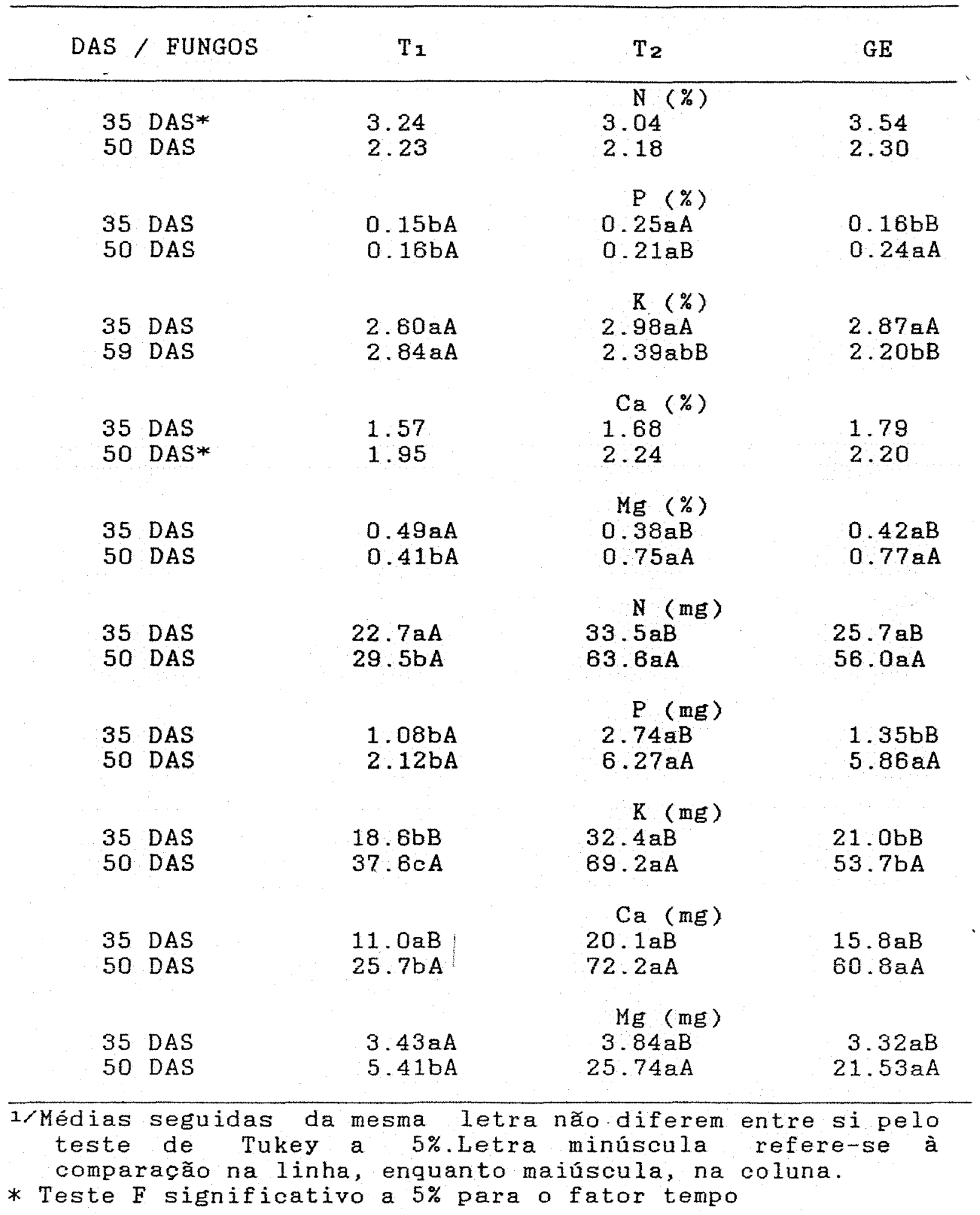


Observou-se que aos 35 DAS (Tabela 16) nå houve diferenca significativa entre tratamentos, quanto à quantidade acumulada de $\mathrm{N}$, Ca e $\mathrm{Mg}$; o acúmulo de $\mathrm{P}$ e $\mathrm{K}$, no entanto, foi significativamente maior em $T_{2}$, ao passo que $T_{1}$ e as plantas micorrizadas náo diferiram entre si. Já aos 50 DAS, as plantas da testemunha $\left(\mathrm{T}_{2}\right)$ e as colonizadas pelo fungo não diferiram entre $s i$, exceto para o $K$, mas superaram significativamente $T_{1}$, sendo que os acúmulos relativos ocorridos em função da micorrização foi de $90 \%$, $176 \%, 43 \%, 137 \%$ e $298 \%$, respectivamente para N, $P, R, C a$ $\mathrm{Mg}$. As quantidades acumuladas de macronutrientes aumentaram de forma significativa aos 50 DAS, principalmente nas plantas $T_{2}$ e nas micorrizadas, sendo que nas últimas ocorreram os maiores incrementos, ou seja $118 \%, 334 \%, 156 \%$, $285 \%$ e $549 \%$ para o $\mathrm{N}, \mathrm{P}, \mathrm{K}, \mathrm{Ca}$ e $\mathrm{Mg}$, respectivamente.

Com relação ao teor e quantidade acumulada de Zn e Cu na parte aérea (Tabela 17), constatou-se que, aos 35 DAS, os tratamentos não diferiram entre si quanto ao $\mathrm{Zn}$; as plantas micorrizadas apresentaram um teor de Cu $140 \%$ e $71 \%$ maior que $T_{1}$ e $T_{2}$, respectivamente, e uma quantidade acumulada $142 \%$ superior a $T_{1}$, na diferindo, entretanto, de $T_{2}$. Aos 50 DAS, observou-se que $T_{1}$ apresentou significativamente maior teor de $\mathrm{Zn}_{n}$ do que $\mathrm{T}_{2}$ e as plantas micorrizadas; estas superaram $\mathrm{T}_{2}$ em $82 \%$, no teor de $\mathrm{Cu} \mathrm{na}$ parte aérea, năo diferindo de $T_{1}$. Entretanto, a guantidade acumulada de $\mathrm{Zn}$ foi significativamente maior nas plantas $\mathrm{T}_{2}$ e colonizadas por $G$. etunicatun (superaram $\mathrm{T}_{1}$ em $42 \%$ ), as quais ainda tiveram um acúmulo de Cu significativamente maior que $\mathrm{T}_{1}$ e $\mathrm{T}_{2}$, com incrementos de $108 \%$ e $47 \%$, respectivamente. De modo geral, os acúmulos tiveram um aumento considerável aos 50 DAS, principalmente nas plantas micorrizadas, que apresentaram $207 \%$ e $109 \%$ mais de $2 n$ e $\mathrm{Cu}$ na parte aérea, respectivamente. 
Tabela 17. Teor e quantidade acumulada de $\mathrm{Zn}$ e $\mathrm{Cu}$ na parte aérea de feijoeiro năo micorrizado ( $\mathrm{T}_{1-}$ Testemunha com $0.3 \mathrm{ppm} P ; \mathrm{T}_{2}$-Testemunha com 3.0 ppm P) e micorrizado (GE- Glonus etunicatun) em duas épocas do ciclo da cultura ( 35 e 50 dias após semeadura - DAS).(Médias de quatro repetições). $1 /$. .

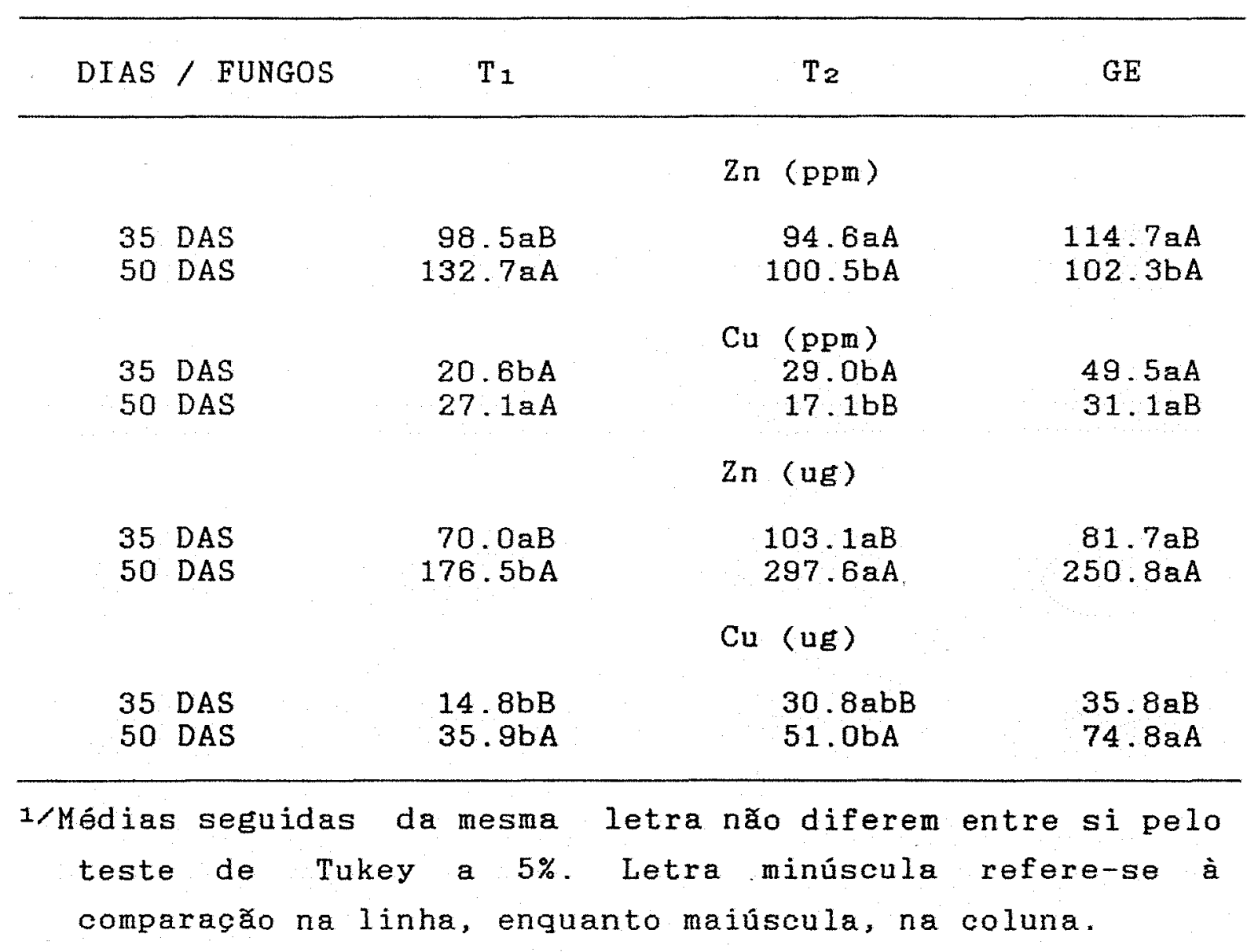




\section{5- DISCUSSAO}

\section{1- Cinética da absorção de $\mathrm{P}$}

Poucos são os trabalhos na literatura que tem por objetivo determinar os parâmetros cinéticos da absorçăo de $P$ por plantas micorrizadas, visando elucidar os mecanismos envolvidos no processo de absorcão de $P$ pela simbiose. A afirmaço de COOPER (1984), de que as modificacões fisiológicas oriundas do estabelecimento da micorriza podem interferir nos aspectos relacionados ì cinética de absorção, translocação e utilização do P, foi plenamente confirmada pelos resultados obtidos no presente estudo.

No experimento I, observou-se um efeito considerável do nível de $P$ adicionado ao substrato, prinoipalmente no comportamento dos endófitos (Tabela 2). Considerando-se o nível mais baixo de $\mathrm{P}$ ( $\mathrm{P}_{1}-0.3 \mathrm{ppm}$ ) constatou-se que as plantas micorrizadas apregentaram uma tendência de aumento no $\mathrm{V}_{\max }$, diminuiço no $\mathrm{K}_{\mathrm{m}}$ e na $\mathrm{C}_{\mathrm{m}} \mathrm{n}$, ocorrendo uma inversão com o aumento no nivel de $\mathrm{P}(\mathrm{Pz}-3.0$ ppm). FAQUIM (1988) também constatou uma diminuição na Vmax com o aumento no fornecimento de nutrientes à planta.

As plantas cultivadas com um fornecimento minimo de $P$ parecem desenvolver um mecanismo mais eficiente de absorcăo do nutriente (EDWARDS e BARBER, 1976) e geralmente apresentam maior $V_{\max } e$ menor $\mathrm{K}_{\mathrm{m}}$ (ANGHINONI $e$ BARBER, 1980; LEE, 1982; McLACHLAN et alii, 1987), conforme - observado na menor dose de $\mathrm{P}$ empregada no experimento $I$.

O efeito mais drástico da adição de maior dose de $\mathrm{P}$ foi - observado nas plantas colonizadas pelo fungo G. etunicatum, que tiveram uma reduçăo de $59 \%$ na $V_{\max }$ (expressa em peso de matéria seca de raiz) e aumento de $57 \%$ no $\mathrm{K}_{\mathrm{m}}$ e $162 \%$ na $\mathrm{C}_{\mathrm{m} i n}$, apesar de terem apresentado os maiores 
pesos de matéria fresca e seca de raiz (Tabela 2). Estes resultados podem ser confrontados com os de FURLANI et alii (1984) que observaram uma taxa menor de absorcăo de $P$ nos genótipos de sorgo que apresentaram as maiores produçós de matéria seca de raiz. Segundo os autores, as menores taxas de absorgăo poderiam ser compensadas pelo maior sistema radicular, o qual teria maior habilidade em explorar o $P$.

A adiça de maior dose de $P$ ao substrato, também causou uma reduça na porcentagem do comprimento de raiz infectada por $G$. etunicatun, mas năo por $s$. heterogama (Tabela 4). Isso talvez esteja relacionado à diminuicão da $V_{m a x}$ já que o número de sitios de absorcão de $\mathrm{P}$ tambem diminuiu, embora a absorçăo de $\mathrm{P}$ não tinha sido prejudicada (Tabela 5), pois, possivelmente, foi compensada pelo aumento no sistema radicular.

Esses resultados confirmam, uma vez mais, a constataço de que a disponibilidade de $\mathrm{P}$ no substrato é o mais importante fator edáfico que afeta a micorriza, pois exerce um efeito duplo, controlando o grau de colonizacão das raízes pelo fungo (MOSSE, 1973) e o grau de micotrofismo (COOPER, 1975).

A inibigão na colonização da raiz com o aumento no fornecimento de $P$, aqui verificado, é o resultado frequentemente observado (ROSS, 1971; MENGE et alii, 1978; SIQUEIRA et alii, 1984; LAMBAIS e CARDOSO, 1988). Em alguns casos, isso ocorre devido à diminuicăo na proporção de rafzes micorrizadas, em funcáo de um estimulo no crescimento do sistema radicular pelo fornecimento de $\mathrm{P}$, o que pode ter ocorrido nas plantas infectadas por $G$. etunicatum, sem que tenha, necessariamente, ocorrido modificacão na habilidade do fungo em infectar a planta (ABBOTT e ROBSON, 1977; BUWALDA et alii, 1982). Essa sensibilidade de G. etunicatum ao nível de $\mathrm{P}$ disponível,-já foi observada em citros por CARDOSO et alii (1986) e ANTUNES e CARDOSO (1990). SeEundo JASPER et alii (1979), quando há aumento no fornecimento de $P$, os isolados de fungo micorrizico podem diferir na sua 
habilidade em infectar as raízes, o que poderia explicar o fato de $\boldsymbol{S}$. heterogama não ter alterado a infeç̧ão da raiz com adição da maior dose de $P$.

Evidencia-se, portanto, que não é possivel fazer generalizaçóes a respeito do efeito de $\mathrm{P}$, bem como de outros fatores, na colonizacão radicular. Há um nível ótimo destes fatores que permite a máxima expressão das caracteristicas genotípicas do endófito, em função da adaptaço diferencial dos isolados às condicões edáficas (LAMBAIS e CARDOSO, 1988).

0 mecanismo pelo qual o $P$ interfere na colonização das raízes pelo fungo ainda não foi esclarecido, mas sabe-se que o responsável pelo controle da colonizaça é o teor de $\mathrm{P}$ na planta. Algumas hipóteses já foram formuladas na tentativa de explicar esse efeito do P: -em condiçóes de deficiencia de $P$, as lectinas da raiz formam dímeros com fosfatases ácidas, facilitando a penetraça do fungo (WOOLHOUSE, 1975); -baixa concentracăo de $P$ na planta induziria uma menor sintese de fosfolipídeos, aumentando a permeabilidade das membranas e, consequentemente, a exsudação de substâncias orgânicas na rizosfera, que estimulariam a penetracão do fungo (RATNAYAKE et alii, 1978); - maior suprimento de $P$ aumenta a concentraça de acúcares nas células corticais, criando condiçós desfavoráveis à penetraço e crescimento do fungo (AZCON e OCAMPO, 1981); - altos niveis de $\mathrm{P}$ na plānta podeira reduzir a colonizaça pelo fungo, devido a menor concentraço de carboidratos soluveis na raiz, como observado em trevo subterrâneo (JASPER et alii, 1979; SAME et alii, 1983).

Apesar de não haver especificidade nas associacoes micorrizicas, tem sido demonstrado que ocorrem certas associaçoses preferenciais entre endófito e hospedeiro, que sao traduzidas pelo Erau de eficiencia da simbiose, que segundo MOSSE (1975) é o grau de vantagem (nutricional ou outra) proporcionado à planta, devido a colonizacáo da raiz pelo fungo. Nesse contexto, os 
resultados obtidos no experimento II confirmam as abservações de SILVEIRA e CARDOSO (1987b), de que as cultivares de feijăo, Carioca e Negro Argel, formam micorrizas mais eficientes, na promoca do crescimento da planta e nutrica mineral, com $G$. etunicatua do que oom $s$. heterogama. Esse efeito positivo do $G$. etunicatun também foi constatado pelos parâmetros cinéticos.

Assim, pelos resultados observados na tabela 7. constatou-se que a micorriza estabelecida por $\boldsymbol{G}$. etunicatum, em ambas as cultivares, apresentou os parâmetros cinéticos de absorçăo de $P$ mais satisfatórios do que a estabelecida por $S$. heterogama, ou seja, maior $V_{m a x}$, menor $\mathrm{K}_{\mathrm{m}}$ e $\mathrm{C}_{\mathrm{m}} \mathrm{n}$. Fato interessante ocorrido é que para plantas com peso de raiz bastante próximos ( $\mathrm{T}-\mathrm{P}_{2}$ e Glomus na cv Carioca, por exemplo) observaram-se valores de $V_{\max }, \mathrm{K}_{\mathrm{m}}$ é $\mathrm{C}_{\mathrm{m} i n}$ com mais de $100 \%$ de vantagem para as plantas micorrizadas, confirmando o papel da simbiose na absorcăo de $\mathrm{P}$, em substratos com baixa disponibilidade de $\mathrm{P}$.

Como no experimento I, Scutellospora apresentou menores porcentagens de comprimento de raiz infectada (Tabela 4 e 9 ) do que Glomus, o que talvez tenha contribuído para a diferenca de resposta observada. Essa menor colonizaça das raizes promovida pelo primeiro endófito já foi constatado por SILVEIRA e CARDOSO (1987b) em três cultivares de feijăo cultivadas en diferentes solos.

Um aspecto a ser considerado nos estudos de absorcăo diz respeito à diferenga que existe entre as plantas, a nivel de cultivar, quanto à capacidade de absorver um dado ion e aos mecanismos envolvidos nessa absorça (CLARK, 1983; LINDGREN et alii, 1977; NIELSEN e BARBER, 1978; FURLANI, 1988; ANGHINONI et aIii, 1989). As cultivares de feijăo empregadas năo apresentaram grandes diferencas nos parâmetros cinéticos. Valores bem próximos de $V_{m a x}$, expressa por planta, foram observados, enquanto que a velocidade por unidade de peso de raiz variou em funcá do crescimento diferencial do sistema radicular das cultivares. 
A maior diferenca entre elas ocorreu nos valores de $K_{m}$, os quais foram maiores na Negro Argel. Os parâmetros cinéticos de absorça iśnica e as caracteristicas morfologicas da raiz são geneticamente controlados, mas, como observado, podem ser modificados pela adubacăo fosfática e pela presenca de fungos micorrizicos.

Os resultados mostram que há viabilidade no emprego dos parâmetros cinéticos da absorção de $\mathrm{P}$ para fins de selecáo de fungos micorrizicos eficientes, visto que a associaço estabelecida por $G$. etunicatum, que mostrou parâmetros cinéticos satisfatórios (NIELSEN e BARBER, 1978; McLACHLAN et alii, 1987), também foi eficiente na promoça do crescimento.

No experimento III, no qual foi verificado o efeito da micorrizaça em duas fases do ciclo da planta, inicio do florescimento ( 35 DAS) e enchimento das vagens ( 50 DAS), constatou-se que $V_{m a x}$ por planta, independente das plantas estarem ou năo micorrizadas, pratioamente não se alterou, ou seja, as raizes tiveram o mesmo número de sitios de absorçăo em ambos os estádios de desenvolvimento (Tabela 12). Entretanto, quando $V_{m a x}$ foi expressa por unidade de peso de raiz, houve uma reducão nas plantas mais velhas ( 50 DAS) concordando com as constataços de WARNCKE e BARBER (1974) e JUNGK e BARBER (1975) em milho e de EDWARDS e BARBER (1976) em soja, mas discordando de DREW et alii (1984) en cevada, que năo obtiveram variaço na $\nabla_{m a x}$, com a idade da planta.

Os valores de $K_{m}$, no entanto, praticamente náo se alteraran oom a idade da planta, o que tamben foi observado em milho (JUNGK e BARBER, 1975), enquanto em plantas mais velhas de soja, o $\mathrm{K}_{\mathrm{m}}$ aumentou (EDHARDS e BARBER, 1976). Já Cmin variou não só com a idade da planta, mas também com o tratamento. Enquanto nas plantas que receberam maior dose de $\mathrm{P}$ ( $\mathrm{T} z$ ) ocorreu um aumento na $\mathrm{C}_{\mathrm{m}}$ com o envelhecimento da planta, concordando com EDWARDS e BARBER ( 1976), nas plantas micorrizadas houve uma redução de 5 
vezes na $C_{m i n}$ nas plantas mais velhas, o que confirma a observação de JUNG e BARBER (1975). Como a porcentagem do comprimento de raiz infectada triplicou dos 35 aos 50 DAS (Tabela 15), pode-se levantar a hipótese de que essa diminuicao na Cmin tenha sido consequencia do aumento da infeccáo radicular.

De modo geral, nos três experimentos, as plantas colonizadas por $G$. etunicatum apresentaram as maiores porcentagens de infecço na raiz, o que pode ter sido a causa dessas plantas terem mostrado os maiores valores de $V_{\text {max }}$ e menores $C_{m 1 n}$.

SANDERS et alii (1977) e GRAHAM et alii (1982) sustentam a idéia de que aumento no crescimento da planta, em funçáo da maior absorção de $\mathrm{P}$ promovida pela presença da micorriza, é proporcional à extensão do desenvolvimento da hifa externa, a qual está correlacionada com a quantidade de infecça a (SANDERS et alii, 1977; KUCEY e PAUL, 1982). HEPPER (1981) observou que a proporção entre o micélio externo e interno foi de $1: 1$, enquanto GRAHAM et alii (1982) não obteveram correlação entro infeccão mimrrimian o a guantidade de hifa externa A discrepância nos resmltados observados na literatura é decorrente das diferenças de metodologia, bem como da influência de fatores como o nivel de $\mathrm{P}$ disponivel (SANDERS et alii, 1977; ABBOTT et alii, 1984) e pH do solo (GRAHAM et alii, 1982) gue afetam de forma diferente o micélio interno e externo, dependendo da espécie fúngica. Nesse aspecto, PACOVSKY et alii (1986a) constataram que a biomassa fúngica intraradicular variou muito mais com a espécie de fungo do que a porcentagem de colonização, sendo que a extensão da colonizacão e a resposta de crescimento foi especifica para cada hospedeiro, o que também foi constatado no experimento I I.

As diferenças de comportamento entre os endófitos também sao esperadas. ABBOTT e ROBSON (1985) constataram que alguns endófitos que apresentaram um 
reduzido micélio externo causaram um maior crescimento da planta do que outros com abundante micélio, talvez porque, apesar de escasso, estivesse melhor distribuido no solo, o que segundo TINKER (1975) é fundamental para maior absorção de nutrientes. Portanto, a resposta positiva de Glomus pode não ter sido necessariamente devido a maior colonização das raízes, mas talvez, à melhor distribuicăo do micélio externo no solo.

$$
\text { Analisando-se conjuntamente os três }
$$

experimentos quanto à cinética de absorção de $P$, observa-se que, de modo geral, as plantas micorrizadas apresentaram maior $V_{\max }$, menor $K_{m}$ e $C_{m}$ in. Comparando-se os resultados obtidos com os escassos dados da literatura, constatou-se que o aumento em $V_{\max }$ concorda com as observações de KARUNARATNE et alii (1986) e FAQUIM (1988) em soja, e significa que houve um aumento no número de sitios de absorca por unidade de raiz, conferido pelas hifas externas do fungo, ou no número de giros do carregador na membrana plasmática (DREW et alii, 1984).

Menor $K_{m}$ em planta micorrizada só foi observado por CRESS et alii (1979) en raiz destacada de tomateiro, cujo trabalho, no entanto, é passivel de criticas: a atividade da raiz quanto à absorça de um determinado íon é comandada pela demanda da parte aérea (JUNGK e BARBER, 1975), e portanto, o emprego de raiz destacada no estudo de cinética náo reflete a absorcão real do nutriente; as plantas micorrizadas e năo mioorrizadas não foram cultivadas nas mesmas condicóes de disponibilidade de $P$, ou seja, as primeiras receberam fosfato solúvel, e as últimas, fosfato de baixa solubilidade; conforme criticado por KARUNARATNE et alii (1986), as plantas de tomate passaram por privaçăo de $P$ por 8 dias, período este que deveria se limitar a $1-2$ dias. Segundo LEE (1982), as plantas que passam por um periodo de deficiencia do elemento aumentam a concentraça de carboidratos na raiz, e com o fornecimento do ion, sua absorçào é mais rápida. No 
presente estudo, no entanto, as plantas receberam a mesma forma de fosfato solúvel em todos os experimentos, passaram por um perfodo de privaca de $P$ de 40 horas conforme metodologia descrita) e mesmo assim, apresentaram menor $\mathrm{K}_{\mathrm{m}}$. Diminuicăo no valor de $K_{m}$ significa que houve um aumento de afinidade ao ion, ou seja, as plantas micorrizadas apresentaram uma maior afinidade ao $P$ dada pela hifa e/ou pela raiz infectada. A observaçăo de CARTWRIGHT (1972) e LEE (1982) de que a deficiência de $\mathrm{P}$ é a principal causa da diminuiçăo do $\mathrm{K}_{\mathrm{m}}$, não se aplica aos resultados obtidos neste experimento, pois estes mostraram justamente o contrário, como no experimento II onde as plantas melhor nutridas em $P$ (Tabela 10) tiveram menor $K_{m}$ (Tabela 7), principalmente as micorrizadas.

Os menores teores de $\mathrm{P}$ observados nesse trabalho, $0.11 \%$ a $0.18 \%$ (Tabelas 5,10 e 16), apesar de serem considerados deficientes para o feijoeiro (WILCOX e FAGERIA, 1976), talvez ainda năo tivessem atingido niveis de deficiência capazes de realmente induzir diminuicăo no valor do $\mathrm{K}_{\mathrm{m}}$, ou seja, as plantas precisariam estar com maior deficiência en $P$. Esses resultados também discordam de FAQUIM ( 1988 ) que observou maior $K_{m}$ em plantas de soja deficientes em $\mathrm{P}$ (0.05\% P).

Menores valores de $\mathrm{C}_{\mathrm{m} i n}$ observados nas plantas micorrizadas, salvo algumas exceçóes, significam que as plantas foram capazes de extrair e reter o P nas raizes, mesmo a baixas concentraçoes na solução, o que concorda com FAQUIM (1988). PACOVSKY e FULLER (1986) conoluíram que as plantas micorrizadas podem usar o P-lábil do solo. Esse mecanismo desenvolvido pela micorriza é importante, principalmente nas regizes tropicais, onde a disponibilidade de $P$ na solução do solo é baixa. Além disso, essa caracteristica pode estar relacionada ao fator adaptativo das espécies fúngicas, isto é, talvez as espécies encontradas em regioes de cerrado tenham a capacidade de alcancar valores de Cmin menores que as nativas de solos 
mais férteis.

Quanto so influxo de $P$, os resultados observados concordam plenamente com as constataços de SANDERS e TINKER (1973), SMITH (1982), FAQUIM (1988), SMITH (1990) e outros, de que as plantas micorrizadas apresentam maior influxo de $P$ de que as năo micorrizadas, nas mesmas condicoes ambientes. Isto significa que para uma mesma concentracáo externa de $P$, a planta micorrizada absorve mais $P$ do que a nă micorrizada, on porque possui maior $V_{\max }$ que tem maior efeito no influxo do que o $\mathrm{K}_{\mathrm{m}}$ (VILELA e ANGUINONI, 1984) ou porque possui maior afinidade ao $P$, menor $K_{m}$. No experimento $I$, as tendências observadas no influxo liquido foram as mesmas, independetemente de ser expresso em unidade de peso de raiz ou por planta (Tabela 3 , Figuras 2,3 e 4 ), concordando com as constataçóes de FAQUIN (1988) em soja. Observou-se que os maiores influxos foram obtidos nas plantas colonizadas, tanto por $G$. etunicatum como por S. heterogama, na menor dose de $P$. O menor influxo foi constatado nas plantas infectadas por $G$. etunicatum na maior dose de $\mathrm{P}$ adicionada, mesmo quando expresso por planta, apesar de ter produzido maior peso de raiz. Essa observaça não concorda com a de SMITH (1982) que obteve maior influxo de $P$ em plantas micorrizadas em todas as doses de $P$. Menor efluxo aparente (Tabela 3 ) foi observado nas plantas colonizadas por G. etunicatum na menor dose de $P$, ou seja, as plantas tiveram maior capacidade de reter o $\mathrm{P}$ na raiz, en condicoos de baixa disponibilidade de $P$ na solucão. 0 contrário ocorreu na maior dose de $\mathrm{P}(\mathrm{Pa})$, havendo maior perda de $\mathrm{P}$ da raiz.

No experimento II, além do efeito da micorrizaço da planta, tambem foi verificado diferenca no comportamento das cultivares e da combinacão cultivar-fungo com relaçăo ao influxo liquido de $P$ (Tabela 8, Figuras 6,7 e 8). A cultivar carioca colonizada por $G$. etunicatum sempre apresentou maior influxo, independentemente da unidade empregada para expressá-1o, o que năo ocorreu con a cultivar 
Negro Argel. 0 efluxo aparente, no entanto, sempre foi menor nas plantas colonizadas por $G$. etunicatum (Tabela 8), em ambas as cultivares. Isto confirma a possibilidade, já digoutida, do emprego da cinética de absorcão para seleção de fungos eficientes. SANDERS et alii (1977) também verificaram que aumento no influxo ocorreu en endofitos eficientes na reducáo da proporcăo raiz:parte aérea.

No experimento III, observou-se que as plantas mais jovens micorrizadas apresentaram 0 maior influxo $e$ influxo liquido de $P$ por unidade de peso de raiz, provavelmente porque apresentaram menor peso de raiz associado a uma maior $V_{\max }$ (Tabela 13 e 14 , Figuras 10 e 11). LINDGREN et alii (1977), en feijoeiro, também constataram correlacáo negativa entre peso seco de raize taxa de absorcăo de $P$. Quando o influxo e influxo líquido foram expressos por planta, as plantas micorrizadas, em ambos os estadios de desenvolvimentos, superaram a testemunhas (Tabela 13 e 14 , Figuras 12 e 13 ), porque apresentaram maior $V_{\max }$. Menor ef luxo aparente (Tabelas 13 e 14) foi observado pelas plantas micorrizadas mais velhas ( 50 DAS), provavelmente, porque apresentaram maior infeccáo radicular e menor $C_{m i n}$ retendo, portanto, mais $\mathrm{P}$ na raiz e/ou na hifa.

SMITH (1982) constatou que a porcentagem de infeccăo na raiz de trevo afetou o influxo de $P$, principalmente em plantas jovens (SMTTH, 1980), ou seja, nestas, a fraça da infecção radicular que está ativa é maior, havendo grande desenvolvimento de arbúsculos. No presente experimento, ocorreu pequena infeccao nas plantas mais jovens ( 35 DAS) o que, no entanto, não descarta a possibilidade de ser mais ativa, gerando maior $v_{\max } e$ influxo de $P$. Já nas plantas mais velhas, a maior $V_{\text {max }} e$ influxo talvez tenham sido consequência da maior infeccão radicular (JAKOBSEM, 1986) causando menor C $\mathrm{C}_{\mathrm{m}}$.

Embora os mecanismos pelos quais as plantas micorrizadas apresentam maior absorça de $P$ ainda não tenham 
sido esclarecidos, FAQUIM (1988) relacionou alguns aspectos da fisiologia e bioguimica da simbiose que podem estar envolvidos: 1- as plantas micorrizadas apresentam um teor de $P$ orgânico ( $P_{0}$ ) nas folhas superior ao das não micorrizadas (ALLEN et alii, 1981; PEREIRA et alii, 1987), o que pode ser atribuído a maior taxa de conversão de $\mathrm{P}$ inorgânico ( $\mathrm{Pi}$ ) a Po, constatado em plantas micorrizadas (BIELESKI, 1973). Isso acarretaria um aumento no gradiente de Pi das raizes para as folhas, facilitando a absorga de $P$, e portanto, aumentando $V_{\max }$ e diminuindo $\mathrm{C}_{\min } ; 2$ - há constatação da atividade de enzimas, como a quinase de polifosfato, envolvidas na formaçăo de grânulos de polifosfato na hifa fúngica (CAPPACIO e CALLOW, 1982), o que levaria a uma baixa concentraçăo interna de Pi, e portanto, diminuição do efluxo de $\mathrm{P} ; \quad 3$ - alta atividade de polifosfatases em planta micorrizada, principalmente na hifa interna (CALLOW et alii, 1978), que estariam envolvidas na quebra de polifosfatos e liberaça de. $P i$, que seria, então, transferido dos arbúsculos para o hospedeiro, mantendo um nivel baixo de $\mathrm{Pi}$ na raiz (BONFANTE-FASOLO e GRIPPIOLO, 1982); 4-presença de fosfatager alcalinas de origem fúngica podem estar envolvidas no processo de absorção ativa de $P$ (COOPER, 1984 ).

Além desses aspectos, que de certa forma esta mais relacionados à absorgão de $\mathrm{P}$, deve-se considerar que outras alteracoes fisiológicas também podem estar contribuindo para modificar os parametros cinéticos e a absorção de $P$, como por exemplo, a menor resistência das plantas micorrizadas à absorcão e translocacão de água e nutrientes (KRISHMA et alii, 1981), maior producăo de fatores de crescimento e hormonios (ALLEN et alii, 1980 e 1982), e alteraço em constituintes quimicos celulares ou aparecimento de outros especificos de plantas micorrizadas (PACOVSKY e FULLER, 1988; HO, 1977). 


\section{2 - Crescimento e nutrição mineral}

Para determinar o efeito da colonizacáo por fungo micorrízico no desenvolvimento e nutriço mineral do hospedeiro, devem ser empregadas plantas não micorrizadas, mas morfo e nutricionalmente similares às micorrizadas (PACOVSKY e FULLER, 1986). Ou seja, em um substrato com pouco P disponivel, plantas na micorrizadas devem ser supridas com $P$ suficiente para alcancar, supostamente, o mesmo grau de desenvolvimento fisiológico que permita a comparaça com plantas micorrizadas (PACOVSKY et alii, 1986a). Para SMITH e DAFT ( 1977 ) e PACOVSKY (1986) comparaçes entre plantas micorrizadas e não micorrizadas só devem ser feitas se estas tiverem peso de matéria seca de parte aérea, proporçăo raiz:parte aérea e teor de $\mathrm{P}$ similares e estiverem no mesmo estádio de desenvolvimento. Baseando-se nessa premissa, utilizou-se em todos os experimentos uma testemunha, planta não micorrizada, que recebeu uma dose de $P(3.0 \mathrm{ppm})$ que the garantiu um adequado desenvolvimento, e que foi considerada uma planta melhor nutrida, principalmente em P. Assim, esperava-se que as plantas micorrizadas, adubadas com $1 / 10$ $d a$ concentraçăo de $P$, tivessem crescimento e estado nutricional similares à testemunha melhor suprida em $\mathrm{P}$. Os resultados do presente trabalho indicaram que, no geral, pelo menos para o peso de matéria seca da parte aérea (PMSPA) e teor de P na parte aérea, as plantas micorrizadas não diferiram das testemunhas que receberam maior dose de $P$ $\left(\mathrm{T}_{2}\right)$, as quais foram, portanto, um controle adequado.

Com relaçăo ao crescimento das plantas, constatou-se que no experimento $I$, as maiores produczes de matéria seca (Tabela 4) e as maiores eficiências relativas (Tabela 18) foram observadas nas plantas colonizadas por G. etunicatum em ambas as doses de $P$ adicionadas $e$ nas colonizadas por $S$. heterogama na maior dose de $P$, as quais 
Tabela 18. Relaçăo raiz:parte aérea (R/PA), eficiência relativa da simbiose (ERS) e indice de utilizaç̃o de $P$ para nodulaça (IUP) no feijoeiro não micorrizado ( $\mathrm{T}$ - Testemunha) e micorrizado (GEGlonus etunicatum; SH-Scutellospora heterogama), com dois niveis de $\mathrm{P}\left(\mathrm{P}_{1}-0.3 \mathrm{ppm} ; \mathrm{P}_{2}-3.0 \mathrm{ppm}\right)$.

\begin{tabular}{cccc}
\hline TRATAMENTOS & R:PA & ERS $1 /$ & IUP \\
& g/g & $\%$ & $\mathrm{mg} / \mathrm{m}$ \\
& & & \\
$\mathrm{T}-\mathrm{P}_{1}$ & 0.87 & $(37) 3 / 2$ \\
$\mathrm{~T}-\mathrm{P}_{2}$ & 0.71 & 34 & 12.8 \\
$\mathrm{GE}-\mathrm{P}_{1}$ & 0.64 & 39 & 25.0 \\
$\mathrm{GE}-\mathrm{P}_{2}$ & 0.91 & 12 & 30.8 \\
$\mathrm{SH}-\mathrm{P}_{1}$ & 0.92 & 40 & 10.4 \\
$\mathrm{SH}-\mathrm{P}_{2}$ & 0.74 & & 17.8
\end{tabular}

$1 /$ ERS $(\%)=$ MS planta nicorrizada - MS $\left(T-P_{1}\right) \times 100$ MS planta micorrizada a $/ \mathrm{IUP}=\mathrm{MS}$ nódulo $\mathrm{P}$ acumulado ( $\mathrm{mg} / \mathrm{mg}$ ) a/Eficiencia de $\mathrm{T}-\mathrm{P}_{2}$ em relaça a $\mathrm{T}-\mathrm{P}_{1}$.

na diferiram da testemunha melhor suprida en $P$. Essa observasáo é particularmente importante, quando o objetivo é selecionar fungos eficientes, pois a eficiencia da associaçăo é variável com a disponibilidade de $P$ no solo (SPARLING e TINKER, 1978, CLARKE \& MOSSE, 1981; KUO E HUANG, 1982). Alem disso, ainda observou-se que, enquanto a colonizacáo das plantas por $G$ etunicatun diminuiu com o aumento na adicão de $P$, esta $n$ ão influenciou a taxa de colonizacão por S. heterogama. 
Nesse caso, parece que a alteração no nivel de $P$ no substrato afetou principalmente a habilidade do fungo em promover aumento no crescimento das plantas (Tabela 4). Assim, enquanto G. etunicatun foi eficiente em ambas as doses de $\mathrm{P}$, apesar da variaça na infecção, $\boldsymbol{S}$. heterogana só diferiu da testemunha suprida com menor nivel de $P$, quando houve maior adicăo de $\mathrm{P}$ ( $\mathrm{P}_{2}$ ). Segundo MOSSE (1981), a eficiência simbiótica é afetada por fatores que controlam o alastramento do fungo no solo, como o nivel de $\mathrm{P}$ disponível (ABBOTT et alii, 1984) e que afetam a translocaçäo e a liberacăo do $\mathrm{P}$ na raiz do hospedeiro.

No entanto, esses resultados năo foram observados quanto à nodulaçăo e fixação de $\mathrm{Nz}$. Nesse caso, constatou-se um efeito apreciável do $G$. etunicatun, principalmente na maior dose de $\mathrm{P}$ (Tabela 4), que também foi mais eficiente no uso do $\mathrm{P}$ para produção de nódulos (Tabela 18), apresentando uma relação $\mathrm{P} / \mathrm{N}$ maior (Tabela 19). Esse efeito benéfico do estabelecimento da associação micorrizica, bem como o efeito sinergístico decorrente da presença da dupla associaçăo, fungo micorrizico e bactéria fixadora de $\mathrm{N}_{2}$, no feijoeiro, já foram demonstrados por DAFT e EL-GIHMI (1974), SILVEIRA e CARDOSO (1987a,b) e FERREIRA (1987).

Uma maior nodulação e fixação do $\mathrm{N}_{2}$ na maior dose de $P$ já era esperada, pois segundo GRAHAM e ROSAS (1979) e BONETTI et alii (1984), PEREIRA e BLISS (1987), a fixaça do $\mathrm{Nz}$ no feijoeiro esta altamente correlacionada com a adubacão fosfática e teor de $\mathrm{P}$ nos nódulos, pois estes são considerados grande consumidores de $\mathrm{P}$ (SAITO e RUSCHEL, 1978). O aumento na nodulaça promovido pelo $\mathrm{P}$ e pela micorriza também já foi demonstrado por SILVEIRA e CARDOSO $(1987 \mathrm{a})$. 
Tabela 19. Relaço entre a concentracão de alguns nutrientes na parte aérea de feijoeiro não micorrizado ( $T$ Testemunha) e micorrizado (GE-Glomus etunicatum; SH-Scutellospora heterogana), com dois niveis de $\mathrm{P}\left(\mathrm{P}_{1}-0.3 \mathrm{ppm} ; \mathrm{P}_{2}-3.0 \mathrm{ppm}\right)$.

\begin{tabular}{cccccc} 
TRATAMENTOS & $\mathrm{P} / \mathrm{N}$ & $\mathrm{P} / \mathrm{Zn}$ & $\mathrm{P} / \mathrm{Cu}$ & $\mathrm{P} / \mathrm{Mn}$ & $\mathrm{Mn} / \mathrm{Ee}$ \\
\hline & & & $\% / \%$ & \\
& & & & \\
$\mathrm{~T}-\mathrm{P}_{1}$ & 0.04 & 15.6 & 70.0 & 1.14 & 6.22 \\
$\mathrm{~T}-\mathrm{P}_{2}$ & 0.08 & 30.7 & 192.3 & 3.46 & 3.36 \\
$\mathrm{GE}-\mathrm{P}_{1}$ & 0.08 & 26.5 & 147.7 & 2.95 & 3.74 \\
$\mathrm{GE}-\mathrm{P}_{2}$ & 0.10 & 37.3 & 227.9 & 2.83 & 4.30 \\
$\mathrm{SH}-\mathrm{P}_{1}$ & 0.06 & 26.3 & 162.2 & 2.74 & 4.29 \\
$\mathrm{SH}-\mathrm{P}_{2}$ & 0.08 & 42.4 & 218.8 & 3.10 & 4.31 \\
\hline
\end{tabular}

No experimento. II, constatou-se que, quanto à produça de matéria seca (Tabela 9) e eficiencia relativa da simbiose (Tabela 20), somente as plantas colonizadas por G. etunicatum foram similares às não micorrizadas que receberam maior dose de P. Baseando-se nas observaços do experimento $I$, tal resultado é plenamente justificado, pois este endófito para gerar simbioses mais eficientes necessitou de maior nivel de $P$ disponivel no substrato. A diminuiça na relação raiz:parte aérea nas plantas micorrizadas e năo micorrizadas que receberam maior dose de P (Tabela 20) indicou um aumento na parte aérea, que, no entanto, foi variável para cada cultivar. 
Tabela 20. Relaçào raiz:parte aérea (R/PA), eficiência relativa da simbiose (ERS) e índice de utilização de $P$ para nodulacão (IUP) em duas cultivares de feijão (Carioca e Negro Argel) na ausencia ( $T-P_{1-}$ Testemunha com $0.3 \mathrm{ppm} \mathrm{P} ; \mathrm{T}-\mathrm{P}_{2}-$ Testemunha com $3.0 \mathrm{ppm}$ P) e presenca de micorriza (GE-Glomus etunicatun; SH- Scutellospora heterogama).

\begin{tabular}{lccc}
\hline TRATAMENTOS & R:PA & ERS1/ & IUP2/ \\
\hline CARIOCA & g/g & $\%$ & $\mathrm{mg} / \mathrm{mg}$ \\
T-P 1 & 1.20 & - & 5.22 \\
T-P2 & 0.99 & $(44) 3 /$ & 16.04 \\
GE & 0.89 & 43 & 10.86 \\
SH & 0.96 & 28 & 5.04 \\
NEGRO ARGEL & 1.12 & & 9.15 \\
T-P 1 & 0.63 & $(58)$ & 13.67 \\
T-P2 & 0.96 & 54 & 9.56 \\
GE & 0.73 & 35 & 4.53 \\
SH & & & \\
\hline
\end{tabular}

1/ERS $(\%)=$ MS planta micorrizada-MS T-P 1 X 100

MS planta micorrizada

$2 / I U P=M S$ nódulos, $\mathrm{mg} / \mathrm{P}$ acumulado, $\mathrm{mg}$

3/Eficiência de $\mathrm{T}-\mathrm{P}_{2}$ em relação a $\mathrm{T}-\mathrm{P}_{1}$.

0 efeito mais marcante em quase todos os experimentos envolvendo MVA é o aumento do crescimento da planta (LOPES et alii, 1983). A diminuição na relação raiz:parte aérea é indicativo de que a planta micorrizada está sendo mais eficiente na alocação de C (HARRIS et alii, 1985; SNELLGROVE et alii, 1982), produzindo maior massa de parte aérea do que de raiz. Isso pode estar associado a 
aumentos nas taxas de fotossíntese e transpiraçăo observados em plantas micorrizadas, devido a menor resistência difusiva da folha (ALLEN et alii, 1981).

A nodulação das plantas, em ambas as cultivares, foi favorecida pela micorrizacăo por G.etunicatua, mas não por S. heterogama (Tabela 9), provavelmente porque a absorcão de $P$ por este endófito foi baixa (Tabela 10), apesar da maior nodulaça ter ocorrido na testemunha melhor suprida em P. Entretanto, observando-se as tabelas 20 e 21 constatou-se que $\mathrm{T}-\mathrm{P}_{2}$ e as colonizadas por G. etunicatum tiveram semelhantes indices de eficiência de utilizaçăo de $\mathrm{P}$ para nodulação e relação $\mathrm{P} / \mathrm{N}$.

Tabela 21. Relação entre a concentração de alguns nutrientes na parte aérea de duas cultivares de feijão (Carioca e Negro Argel) na ausência ( $\mathrm{T}_{1}$ Testemunha com 0.3 ppm $\mathrm{P} ; \mathrm{Tz}$ - Testemunha com 3.0 ppm P) e presenca de micorriza (GE- Glomus etunicatun).

TRATAMENTOS $\mathrm{P} / \mathrm{N} \quad \mathrm{P} / \mathrm{Fe} \quad \mathrm{P} / \mathrm{Zn} \quad \mathrm{P} / \mathrm{Cu} \quad \mathrm{P} / \mathrm{Mn} \quad \mathrm{Mn} / \mathrm{Fe}$
$\% / \%$

CARIOCA

$\begin{array}{lrrrrrr}\mathrm{T}-\mathrm{P}_{1} & 0.05 & 6.3 & 15.0 & 80.0 & 3.7 & 1.7 \\ \mathrm{~T}-\mathrm{P}_{2} & 0.09 & 5.5 & 18.8 & 146.7 & 5.3 & 1.0 \\ \mathrm{GE} & 0.09 & 6.2 & 17.5 & 59.5 & 3.7 & 1.7 \\ \mathrm{SH} & 0.07 & 8.4 & 18.8 & 81.8 & 11.1 & 0.8\end{array}$

NEGRO ARGEL

$\begin{array}{lllllll}\mathrm{T}-\mathrm{P}_{1} & 0.05 & 5.3 & 12.1 & 68.2 & 3.8 & 1.4 \\ \mathrm{~T}-\mathrm{P}_{2} & 0.09 & 6.7 & 23.5 & 118.8 & 4.0 & 1.7 \\ \mathrm{GE} & 0.08 & 7.8 & 24.4 & 69.0 & 5.0 & 1.6 \\ \mathrm{SH} & 0.06 & 2.0 & 17.0 & 61.5 & 6.3 & 0.3\end{array}$


Segundo BARRADAS et alii (1989) e HUNGRIA $\theta$ NEVES (1986) as cultivares Carioca e Negro Argel são bastante similares com relaça à fixação do $\mathrm{Nz}$, dai não terem ocorrido grandes diferenças entre elas.

A micorrizaçăo do feijoeiro sô mostrou efeito positivo no crescimento das plantas aos 50 DAS, quando entăo as plantas colonizadas por $G$. etunicatum e as não micorrizadas, mas melhor supridas em $\mathrm{P}$, foram semelhantes na producáo de materia seca (Tabela 15) e efioiencia relativa (Tabela 22).

Tabela 22. Indice de eficiência (IE) na utilização de nutrientes e eficiência relativa da simbiose (ERS) em feijoeiro não micorrizado ( $T_{1}$ Testemunha com 0.3 ppm $\mathrm{P} ; \mathrm{T}_{2}$ - Testemunha com 3.0 ppm P) a micorrizado (GE-Glomus etunicatum) em duas épocas do ciclo da cultura ( 35 e 50 dias após semeadura- DAS).

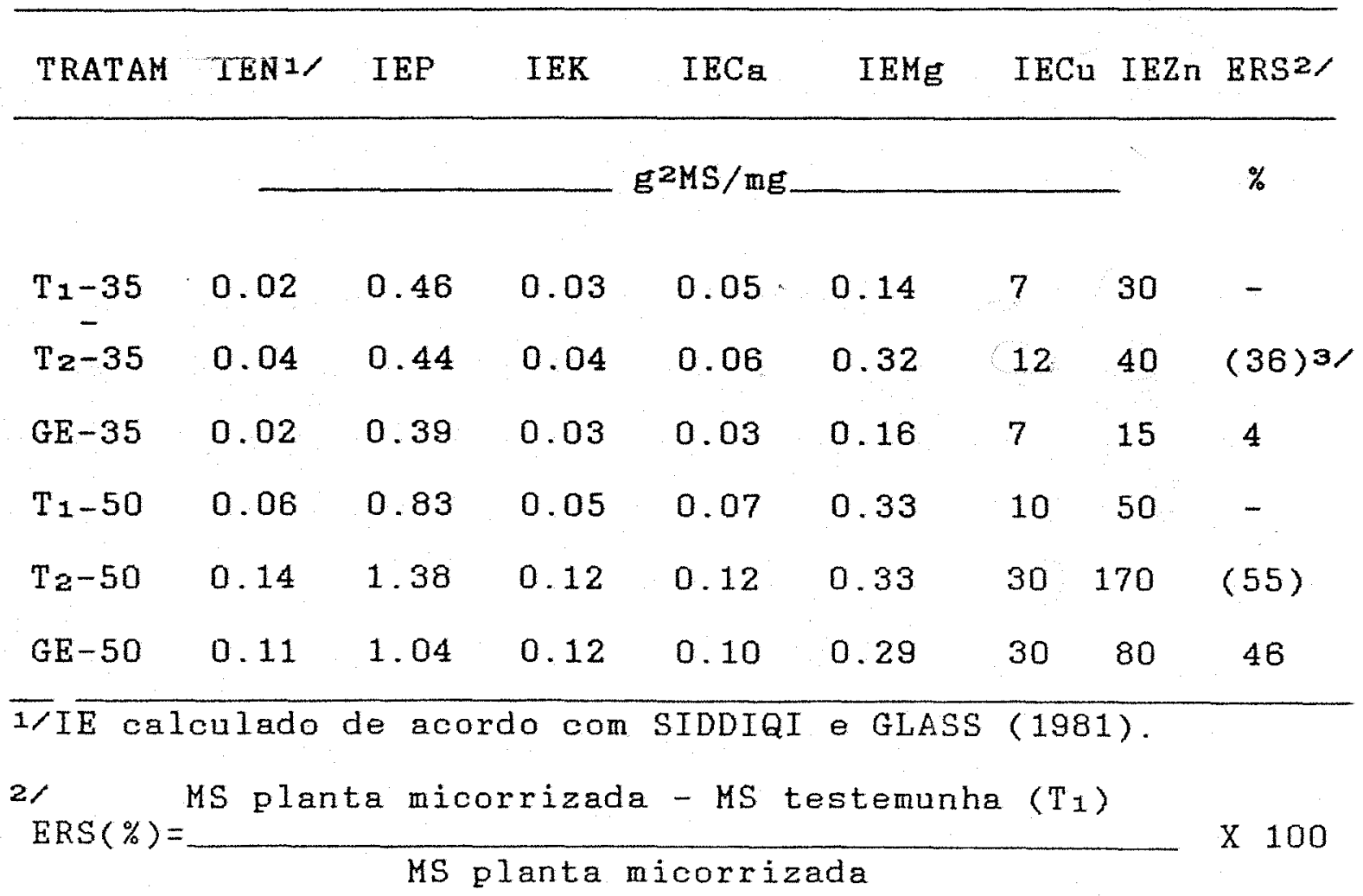

3/Eficiência de $\mathrm{T} z$ em relaça a $\mathrm{T}_{1}$. 
A nodulação destas plantas aos 50 DAS (fase de enchimento das vagens), também foi maior que aos 35 DAS (dados não mostrados) e as plantas tiveram uma relação $\mathrm{P} / \mathrm{N}$ também mais adequada (Tabela 23 ), baseando-se em WILCOX e FAGERIA (1976). Em geral, o que se observa é que após o florescimento inicia-se um processo de senescência dos nódulos e gueda na alividade da nitrogenase (FRANCo et alii, 1979; HUNGRIA et al1i, 1965; IUUHGRIA e NEVES, 1986) A maior nodulaça das plantas aos 50 DAS, provavelmente, ocorreu en função da absorção de $P$ que só foi acumulado satisfatoriamente na planta aos 50 DAS (Tabela 16).

Tabela 23. Relaçăo $\mathrm{P} / \mathrm{N}, \mathrm{P} / \mathrm{Zn}$ e $\mathrm{P} / \mathrm{Cu}$ na parte aérea de feijoeiro não micorrizado ( $T_{I}$ - Testemunha com 0.3 ppm $\mathrm{P} ; \mathrm{Tz}-$ Testemunha com 3.0 ppm $\mathrm{P}$ ) e micorrizado (GE- Glomus etunicatum), em duas épocas do ciclo da cultura ( 35 e 50 dias após semeadura).

TRATAMENTOS $\quad \mathrm{P} / \mathrm{N} \quad \mathrm{P} / \mathrm{Zn} \quad \mathrm{P} / \mathrm{Cu}$

\begin{tabular}{cccc} 
& \multicolumn{3}{c}{$\boldsymbol{\psi} / \boldsymbol{\psi}$} \\
$\mathrm{T}_{1}-35$ & 0.05 & 15.23 & 72.82 \\
$\mathrm{~T}_{2}-35$ & 0.08 & 26.43 & 86.21 \\
$\mathrm{GE}-35$ & 0.05 & 13.95 & 32.32 \\
& & & \\
$\mathrm{~T}_{1}-50$ & 0.07 & 12.06 & 59.04 \\
$\mathrm{~T}_{2}-50$ & 0.10 & 20.90 & 122.81 \\
$\mathrm{GE}-50$ & 0.10 & 23.46 & 77.17 \\
\hline
\end{tabular}


Segundo SMITH (1982) a concentraçăo de nutrientes nos tecidos pode ser afetada pelo efeito de diluicăo, como consequencia do orescimento da planta, não dando, portanto, nenhuma indicaçăo da eficiencia com que o sistema radicular absorve e a planta utiliza determinado nutriente. Como nos experimentos conduzidos ocorreu efeito de diluiçá, principalmente para o $\mathrm{H}$, determinou-se o Indice de eficiencia na utilização do nutriente (SIDDIQI e GLASS, 1981), como uma ferramenta, talvez mais adequada, para auxiliar na interpretação e discussão dos resultados.

As tabelas 5 e 6 , referentes ao experimento $I$, mostram os valores médios do teor e quantidade acumulada de macro e micronutrientes na parte aérea. Se os teores forem comparados com os obtidos ou recomendados por HIROCE et alii ( 1969 e 1970), COBRA NETO et alii (1971), WILCOX e EAGERIA (1976), FEITOSA et alii (1980), MALAVOLTA et alii (1989), verifica-se que as plantas tiveram teores baixos de $\mathrm{N}, \mathrm{P}$ e $\mathrm{K}$, adequados de $\mathrm{Ca}, \mathrm{Mg}, \mathrm{Fe}, \mathrm{Zn}$ e Cu e alto de Mn. 0 teor alto de $M n$, que nas plantas da testemunha ( $\mathrm{T}-\mathrm{P}_{1}$ ) atingiu niveis tóxicos (WILCOX e FAGERIA, 1976) deve ter sido consequência da esterilização do substrato por autoclavagem, que como se sabe, libera Mn (JOHNSON e CURL, 1972). Essa Iiberaçăo de Mn pode ter prejudicado a absorçăo de outros nutrientes e a fixação do $\mathrm{N}_{2}$ (DOBEREINER, 1966).

Comparando-se as tabelas 2,3 e 5 , observa-se que as plantas colonizadas por $G$. etunicatum e que receberam maior dose de $\mathrm{P}$ ( $\left(\mathrm{EE}-\mathrm{P}_{2}\right)$ tiveram a menor $\mathrm{V}_{\mathrm{max}}$, os maiores valores de $K_{m}$ e $C_{m i n} e$ menor influxo liquido, mas foram as que absorveram $e$ acumularam mais $P$ na parte aérea. Provavelmente, isso tenha sido consequência do aumento no sistema radicular provocado pela adicáo de $P$, que compensou o- menor influxo, como constatado por FURLANI et alii (1984). No entanto, observando-se a tabela 24 , constata-se que estas plantas foram pouco eficientes na utilizaçăo do $P$ absorvido, pois a producào de matéria seca foi similar à das plantas dos demais tratamentos, excetuando $\mathrm{T}-\mathrm{P}_{1}$ e $\mathrm{SH}-\mathrm{P}_{1}$ (Tabela 4 ). 
Tabela 24. Indice de eficiência (IE) na utilizaçăo de nutrientes pelo feijoeiro não micorrizado (TTestemunha) e micorrizado (GE- Glomus etunicatum; SH- Scutellospora heterogama), com dois niveis de $\mathrm{P}$ ( $\left.\mathrm{P}_{1}-0.3 \mathrm{ppm} ; \mathrm{Pz}_{2}-3.0 \mathrm{ppm}\right) .1$

TRATAM. IEN IEP IEK IECa IEMg IEE IEZn IECu IEMn $2 /$

\begin{tabular}{lllllllllll}
\hline & \multicolumn{10}{c}{$g=M S / m g$} \\
T-P1 & 0.04 & 1.1 & 0.05 & 0.08 & 0.34 & 8.1 & 17.5 & 84.2 & 1.2 \\
$\mathrm{~T}-\mathrm{P}_{2}$ & 0.09 & 1.2 & 0.11 & 0.13 & 0.77 & 14.2 & 36.1 & 236.6 & 4.3 \\
$\mathrm{GE}-\mathrm{P}_{1}$ & 0.10 & 1.3 & 0.10 & 0.16 & 0.70 & 15.4 & 34.4 & 200.9 & 4.3 \\
$\mathrm{GE}-\mathrm{P}_{2}$ & 0.10 & 1.0 & 0.10 & 0.13 & 0.56 & 12.4 & 36.7 & 205.7 & 3.0 \\
$\mathrm{SH}-\mathrm{P}_{1}$ & 0.07 & 1.1 & 0.07 & 0.09 & 0.48 & 13.7 & 31.2 & 201.2 & 3.2 \\
$\mathrm{SH}-\mathrm{P}_{2}$ & 0.11 & 1.5 & 0.13 & 0.16 & 0.80 & 18.8 & 63.2 & 328.2 & 4.2
\end{tabular}

1/IE calculado de acordo com SIDDIQI e GLASS (1981). 2/Para o Mn considerou-se Indice de resistência da planta, segundo BATAGLIA e MASCARENHAS (1978).

O P absorvido pelas plantas, neste caso, provavelmente beneficiou a nodulaço (Tabela 4 e 18), gerando um incremento de $128 \%$ e $632 \%$ no peso de nódulos em relaçấo a $\mathrm{T}-\mathrm{P}_{2}$ e $\mathrm{T}-\mathrm{P}_{1}$, respectivamente, mas ná favoreceu a fixacào do $\mathrm{Nz}$ com a mésma intensidade (Tabela 4).

Considerando-se que essas plantas (GE-Pz) estavam associada a dois microssimbiontes, fungo micorrizico • rizóbio, sugere-se que o aumento na absorção de $\mathrm{P}$ tenha 
possivelmente desequilibrado o sistema, o que causou um maior dreno de $\mathrm{C}$ (KUCEY e PAUL, 1982; HARRIS et alii, 1985) principalmente pelo rizóbio, já que a nodulação aumentou e a colonizacáo interna pelo fungo diminuiu. Talvez o rizbbio tenha sido mais competitivo que o fungo no aproveitamento do P. CASSMAN et alii (1981) demonstraram que as estirpes de rizóbio săo diferentes quanto ao armazenamento e utilizacào do $P$, podendo ocorrer diferenca na interacão rizóbio-fungo micorrizico e portanto na resposta da dupla simbiose (PACOVSRY et alii, 1986c).

Como já foi dito, excetuando-se a testemunha $\mathrm{T}-\mathrm{P}_{1}$ e as plantas colonizadas por $S$ heterogana com adicao de menor dose de $\mathrm{P}\left(\mathrm{SH}-\mathrm{P}_{1}\right)$, os demais tratamentos tiveram indices de utilizaçào dos macronutrientes (Tabela 24) bem próximos e inclusive similares aos da testemunha melhor nutrida em $\mathrm{P}\left(\mathrm{T}-\mathrm{P}_{2}\right)$. Já com relaçáo aos micronutrientes, observou-se que plantas da testemunha ( $\mathrm{T}-\mathrm{P}_{1}$ ) foram comparativamente pouco eficientes no uso dos nutrientes para producão de matéria seca de parte aérea. Tanto as plantas micorrizadas como $\mathrm{T}-\mathrm{P}_{2}$ (Tabelas 19 e 24 ) foram 3 a 4 vezes mais resistentes ao $M n$ do que $T-P_{1}$, porque absorveram mais $P$ (maior $\mathrm{P} / \mathrm{Mn}$ ) ou, no caso das plantas micorrizadas, retiveram o Hn nas hifas do fungo, diminuindo sua translocaça para a parte aêrea (PACOVSKY, 1986).

Com relação às plantas colonizadas por S. heterogama, no experimento $I$, observou-se que na maior dose de $\mathrm{P}\left(\mathrm{SH}-\mathrm{P}_{2}\right)$ as plantas apresentaram indices relativamente mais elevados de utilizaça de $\mathrm{P}, \mathrm{Zn}$ e $\mathrm{Cu}$ (Tabela 24), isto é, produziram a mesma quantidade de matéria seca que as plantas colonizadas por Glomus e $\mathrm{T}-\mathrm{P}_{2}$ (Tabela 4), mas com menores quantidades absorvidas destes nutrientes (Tabela 5 e 6 ).

Comparando-se os valores médios dos teores de macro e micronutrientes (Tabelas 10 e 11 ), no experimento II, com as análises foliares disponiveis na literatura citada anteriormente, constatou-se que, de modo geral, os 
teores dos nutrientes estăo adequados a cultura. Com base nos dados de WILCOX e FAGERIA (1976), as plantas da cultivar Negro Argel colonizadas por $S$. heterogama apresentaram niveis tóxicos de $F e$, enquanto que as da cultivar Carioca colonizadas por Glomus atingiram niveis tóxicos de $\mathrm{Cu} \theta \mathrm{Mn}$ na parte aérea. Os teores de $M n$, com excegão das plantas colonizadas por Scutellospora, estavam elevados ( acima de 300 ppm).

No Eeral, as plantas micorrizadas năo diferiram de $\mathrm{T}-\mathrm{P}_{2}$ quanto à quantidade acumulada de macronutrientes (Tabela 10) e ao índice de efciência de utilizacào destes nutrientes na producăo de matéria seca (Tabela 25). A mesma tendência foi observada com relaçào aos micronutrientes. As relaçós $\mathrm{Mn} / \mathrm{Fe}$ e $\mathrm{P} / \mathrm{Fe}$ foram bastante alteradas pela colonizaça das plantas por $s$. heterogana, devido à elevada absorga de fe, na ov Hegro Argel, e a adequada absorca do elemento, na Carioca (Tabela 21). As plantas micorrizadas por $G$. etunicatum apresentaram maior teor e scúmulo de $\mathrm{Cu}$ do que $\mathrm{T}-\mathrm{Pz}$ (menor $\mathrm{P} / \mathrm{Cu}$ ), no entanto, não foram tão eficientes quanto estas na sua utilização, pois produziram o mesmo peso de matéria seca (Tabela 9).

Apesar das plantas $\mathrm{T}-\mathrm{P}_{2}$ e as colonizadas por Glomus terem apresentado as maiores quantidades acumuladas de $M n$ na parte aérea (Tabela 11), ainda tiveram o dobro da resistência a esse elemento que as testemunhas ( $\left.\mathrm{T}-\mathrm{P}_{1}\right)$, embora as mais resistentes tenham sido as colonizadas por Scutellospora (Tabela 25). Este endófito, portanto, por algum mecanismo de exclusăo e seletividade (PAKOVSKY, 1986; BETHLENFALVAY E FRANSON, 1989) ou porque foi capaz de manter nas plantas as relaços $\mathrm{P} / \mathrm{Mn}, \mathrm{Ca} / \mathrm{Mn}$ e $\mathrm{Mg} / \mathrm{Mn}$ mais adequadas, conferiu às cultivares maior resistência à absorçăo do Mn, que, provavelmente, estava em maior disponibilidade no substrato e que foi absorvido em altas concentraçóes nos demais tratamentos. 
Tabela 25. Indice de eficiência (IE) na utilizaçá de nutrientes por duas cultivares de feijão (Carioca e Negro Argel) na ausencia ( $\mathrm{T}-\mathrm{P}_{1}$ - Testemunha com $0.3 \mathrm{ppm} \mathrm{P} ; \mathrm{T}-\mathrm{P}_{2}-$ Testemunha com $\left.3.0 \mathrm{ppm} \mathrm{P}\right) \mathrm{e}$ presenca de micorriza (GE-Glomus etunicatum; SHScutellospora heterogama). 1 /

TRATMEN. IEN IEP IEK IECa IEHg IEFe IEZn IECu IEMn
$\mathrm{E}^{2 \mathrm{MS} / \mathrm{mg}}$

\section{CARIOCA}

$\begin{array}{llllllllll}\mathrm{T}-\mathrm{P}_{1} & 0.05 & 0.9 & 0.04 & 0.07 & 0.35 & 5.7 & 13.4 & 72.0 & 3.2 \\ \mathrm{~T}-\mathrm{P}_{2} & 0.10 & 1.2 & 0.09 & 0.15 & 0.55 & 6.6 & 20.6 & 162.8 & 6.1 \\ \mathrm{GE} & 0.11 & 1.2 & 0.08 & 0.13 & 0.42 & 6.9 & 19.7 & 67.6 & 4.1 \\ \mathrm{SH} & 0.08 & 1.1 & 0.04 & 0.11 & 0.47 & 9.3 & 20.3 & 91.2 & 9.3\end{array}$

NEGRO ARGEL

$\begin{array}{lrrrrrrrrr}\mathrm{T}-\mathrm{P}_{1} & 0.04 & 0.8 & 0.04 & 0.06 & 0.28 & 4.5 & 11.3 & 62.5 & 3.4 \\ \mathrm{~T}-\mathrm{P}_{2} & 0.15 & 1.6 & 0.13 & 0.21 & 0.76 & 10.7 & 37.5 & 187.5 & 6.4 \\ \mathrm{GE} & 0.11 & 1.4 & 0.11 & 0.18 & 0.54 & 11.4 & 33.3 & 97.4 & 6.9 \\ \mathrm{SH} & 0.07 & 1.2 & 0.06 & 0.09 & 0.44 & 2.5 & 20.7 & 76.0 & 7.6\end{array}$

1/IE calculado segundo SIDDIQI e GLASS (1981).

Para o Mn considerou-se Indice de resistência da planta, segundo BATAGLIA e MASCARENHAS (1978).

De acordo com as tabelas de analise foliar de feijoeiro, citadas anteriormente, no experimento III, os teorea de $\mathrm{K}, \mathrm{Ca}$ a $\mathrm{HE}$ estavam em niveis adequados, enguanto os demais, de acordo com o tratamento, variaram desde niveis baixos até tóxicos, como o teor de cu nas plantas micorrizadas (Tabela 16 e 17 ).

Apesar de absorver niveis tóxicos de $\mathrm{Cu}$, as plantas micorrizadas năo apresentaram sintomas e não ocorreu diminuiça na producăo de matéria seca (Tabela 15), reduzindo, no entanto, a relacăo $\mathrm{P} / \mathrm{Cu}$, principalmente aos 35 
DAS (Tabela 23). Aos 50 DAS, a relaçăo $P / C u$ aumentou porque houve diminuiçăo no teor de Cu e aumento no $\mathrm{P}$.

A micorrizaçá das plantas somente mostrou algum efeito positivo aos 50 DAS. As quantidades acumuladas de nutrientes foram significativamente maiores aos 50 dias, principalmente na testemunha melhor suprida em $P$ a na colonizada por G. etunicatum, as quais apresentaram os maiores indices de eficiência na utilizaça dos nutrientes (Tabela 22), resultando em maior eficiência da simbiose. A única excecăo foi o $\mathrm{Mg}$, que apesar de ter sido absorvido e acumulado muito mais nestes tratamentos, não contribuiu para maior producáde materia sead gue a testemunha (TI-50).

Como discutido anteriormente, neste experimento, as diferenças no comportamento das plantas micoricháas podem estar relacionadas à porcentagem de comprimento de raiz infectada, que mostrou-se $190 \%$ maior aos 50 DAS. A precocidade no estabelecimento da simbiose é fundamental para garantir um desenvolvimento adequado da planta, que cresce em condicăo de baixa disponibilidade de $\mathrm{P}, \mathrm{e}$ principalmente, para culturas de ciclo curto (BETHLENFALVAY e YODER, 1981). Possivelmente, por algum problema do inóculo, o estabelecimento da associaça foi moroso, se comparado aos demais experimentos nos quais plantas com 30 DAS já apresentavam $60 \%$ de colonizaça (Tabela 4 ).

A observaça de que as plantas micorrizadas, no geral, apresentam maior teor de $\mathrm{Cu} e \mathrm{Zn} e$ menor de $\mathrm{Fe} e$ Mn têm sido demonstrado na literatura (CARDOSO, 1985, 1986; PACOVSKY, 1986; PACOVSKY et alii 1986a; PACOVSKY e FULLER, 1988; BETHLENFALVAY e FRANSON, 1989; ARINES et alii, 1989). Entretanto, conforme os resultados obtidos neste estudo a as observações de LAMBAIS (1987), o estabelecimento da associaça micorrízica pode alterar as exigências nutricionais da planta, além de causar mudanças nas relaçốs entre os nutrientes. Isso talvez justifique o fato de que, como constatado, as plantas micorrizadas cultivadas em 
condicão de baixa disponibilidade de $\mathrm{P}$ foram capazes de utilizar os nutrientes absorvidos de maneira tâo eficiente quanto as plantas que receberam 10 vezes mais $P$, na promocão do crescimento. 


\section{6 - CONCLUSOES}

1- A associaça micorrizica, influenciada pelo nível de $P$ no substrato, pela combinaça cultivar-fungo e pelo estádio de desenvolvimento da planta, afeta os parâmetros cinéticos de absorgão radicular e o influxo de $P$.

2- Há relação entre o micotrofismo e os parâmetros cinéticos de absorção radicular de $P, \quad o$ que permite que a cinética de absorça de $P$ seja empregada como critério de seleção de fungos micorrizicos eficientes.

3- A micorrização do feijoeiro causa alteraça no estado nutricional da planta e nas relagões entre os nutrientes.

4- A planta micorrizada, em condições de baixa disponibilidade de $P$, pode ser tão eficiente quanto à não micorrizada, cultivada em sustrato com maior nível de $P$ disponível, em relação à absorção e eficiência na utilização dos nutrientes. 


\section{7- LITERATURA CITADA}

ABBOTT, L.K. \& ROBSON, A.D. Growth stimulation of subterranean clover with vesicular-arbuscular mycorrhizas. Australian Journal Agriculture Research, Melbourne, 28: 639-49, 1977 .

ABBOTT,L.K. \& ROBSON,A.D. Formation of external hyphae in soil by four species of vesicular-arbuscular mycorrhizal fungi. New Phytologist, Oxford, 99: 245-55, 1985.

ABBOTT, L.K.; ROBSON, A.D.; DE BOER, G. The effect of phosphorus on the formation of hiphae in soil by the vesicular-arbuscular mycorrhizal fungus Glonus fasciculatum. New Phytologist, Oxford, 97:437-46, 1984. MLIN, M.. \& BoOSALIS, M.G. Effects of two species of vesicular-arbuscular mycorrhizal fungi on drough tolerance of winter wheat. New Phytologist, Oxford, 93 : $67-74.1983$.

ALLEN, M.E.; MOORE JR., T.S.; CHRISTENSEN, M. Phytohormone changes in Bouteloa Eracilis infected by vesiculararbuscular mycorrhizae. I- Citokinin increases in the host plant. Canadian Journal of Botany, Ottawa, 58: $371-$ 4,1980 .

ALLEN, M.F.; SMITH, W.K.; MORRE, S.M.; CHRISTENSEN, M. Comparative water relations and photossynthesis of mycorrhizal and non-mycorrhizal Bouteloua fracilis. NeW Phytologist, oxford, 88: 683-93, 1981.

ALLEN, M.F.; MOORE JR., T.S.; CHRISTENSEN, M. Phytohormones changes in Bouteloua gracilis infected by vesiculararbuscular mycorrhizal fungi. II- Altered levels of gibberillin-like substances and abscisic acid in the host plant. Canadian Journal of Botany, Ottawa, 60: 468-71, 1982 .

AMBLER,J.R. \& YOUNG,J.L. Techniques for determining root lenght vesicular-arbuscular mycorrhizae. Soil Science Society American Journal, Madison, 41: 551-6, 1977. 
AMES, R.N.; REID, C.P.P; PORTER, L.K.; CAMBARDELLA, C. Hyphal uptake and transport of nitrogen from two $N-$ labelled sources by Glomus mosseae, a vesiculararbuscular mycorrhizal fungus. New Phytologist, Oxford, 95: $381-96,1983$.

AMES, R.N.; PORTER, L.K.; ST JOHN, T.; REID, C.P.P. Nitrogen sources and "A" values for vesicular-arbuscular and nonmycorrhizal sorghum grown at three rates of $15 \mathrm{~N}$ ammonium sulphate. New Phytologist, Oxford, 97: 269-76, 1984.

ANGHINONI, I. \& BARBER, S.A. Phosphorus influx and growth characteristics of corn roots as influenced by phosphorus supply. Agronomy Journal, Madison, 72: 685-8, 1980.

ANGHINONI, I.; VOLKART, C.R.; FATTORE, N. ; ERNANI, P.R. Morfologia de raizes e cinética da absorção de nutrientes eli diversas espécies e genótipos de plantag.Revigta brasileira de Ciência do Solo, Campinas, 13: 355-61, 1989.

ANTUNES, V. \& CARDOSO, E.J.B.N. Growth and nutrient status of citrus plants as influenced by mycorrhiza and phosphorus application. Elant and Soil, The Hague, 131: - 11-20, 1991.

ARINES, J.; VILARINO, A.; SAINZ, A. Effect of different inocula of vesicular-arbuscular mycorrhizal fungi on manganese content and concentration in red clover (Trifolium pratense L.) plants. New Phytologist, Oxford, 112: 215-9, 1989.

ASIMI, S.; GIANINAZZI-PEARSON, V.; GIANINAZZI, S. Influence of increasing soil phosphorus levels on interactions between vezioular-arbuzcular mycorrhizae and Rhizobium in soybeans.Canadian Journal of Botany, Ottawa, 58: 2200-5, 1980.

AZCON, R. \& OCAMPO, J.A. Factors affecting the vesiculararbuscular infection and mycorrhizal dependence of thirteen wheat cultivars. New Phytolosist, Oxford, 87: $677-85,1981$. 
AZCON, R.; BAREA, J.M.; HAYMAN, D.S. Utilization of rock phosphate in alkaline soils by plants inoculated with mycorrhizal fungi and phosphate-solubilizing bacteria. Soil Biology \& Biochemistry, oxford, 8: 135-8, 1976.

AZCON-AGUILAR, C.; GIANINAZZI-PEARSON, V.; FARDEAU, J.C.;

GIANINAZZI, S. Effect of vesicular-arbuscular mycorrhizal fungi and phosphate-solubilizing bacteria on growth and nutrition of soybean in a neutral-calcareous soil amended with $32 \mathrm{P}-45 \mathrm{Ca}-t r i c a l c i u m$ phosphate. Elant and Soil. The Hague, 96: 3-15, 1986 .

BALIGAR, V.C. Absorption kinetics of $\mathrm{Ca}, \mathrm{Mg}, \mathrm{Na}$ and $\mathrm{P}$ by intact corn and onion roots. Journal of Plant Nutrition, New York, 8: 543-54, 1985.

BALIGAR, V.C. \& BARBER, S.A. Genotypics differences of corn So- ion uptake. Agronomy Journal, Madison, 71: 870-3, 1979 .

BAREA, J.M. \& AZCON-AGUILAR, C. Production of plant growth regulating substances by the vesicular - arbuscular mycorrhizal fungus Glomus mosseae. Applied Enviromental flcrobiology, Baltimore, 43: 810-3, 1982.

BAREA, J.M. \& AZCON-AGUILAR, C. Mycorrhizas and their significance in nodulating nitrogen - fixing plants. Advances in Agronomy, New York, 38: 1-54, 1983.

BAREA, J.M.; ESCUDERO, J.L.; AZCON-AGUILAR, C. Effects of introduced and indigenous VA mycorrhizal fungi on nodulation, growth and nutrition of Medicago sativa in phosphate-fixing soils as affected by $P$ fertilizers. Blant and Soil, The Hague, 54: 283-96, 1980.

BAREA, J.M.; AZCON-AGUILAR, C.; AZCON, R. Vesiculararbuscular mycorrhiza improve both symbiotic $\mathrm{Na}$ fixation and $N$ uptake from soil as assessed with a $15 N$ technique under field conditions. New Phytologist, Oxford, 106: $717-25,1987$. 
BARRADAS, C.A.; BOdDEY, L.H.; HUNGRIA, M. Seleça de cultivares de feijăo e estirpes de Rhizobium para nodulação precoce e senescência tardia dos nódulos.Revista brasileira Ciência solo, Campinas, 13 : $169-79,1989$.

BAR-YOSEF, B. \& KAFKAFI, U. A new aproach to evaluating the effective root area of field crops. Advances in Plant Nutrition, 1: 281-90, 1971.

BATAGLIA, O.C. \& MASCARENHAS, H.A.A. Absorcão de nutrientes pela soja. Campinas, Instituto Agronômico, 1978. 36p. (Boletim Técnico, 41).

BELL, M.J.; MIDDLETON, K.J.; THOMPSON, J.P. Effects of vesicular-arbuscular mycorrhizae on growth and phosphorus and zinc nutrition of peanut (Arachis hypogaea L.) in an Oxisul pron subtropical Australia. Rlant and Soil, The Hague, 117: 49-57, 1989.

BETHLENFALVAY, G.J. \& FRANSON, R.L. Manganese toxicity alleviated by mycorrhizae in soybean. Journal Plant Nutrition, New York, 12: 953-70, 1989.

BETHLENAALVAY: G.J. \& YODER, J.F. The Glycine-GlomusRhizobiug symbiosis. I-Phosphorus effect on nitrogen fixation and mycorrhizal infection. Physiologia Plantarum, Copenhagem, 52: 141-5, 1981.

BETHLENFALVAY, G.J.; BROWN, M.S.; PACOVSKY, R.S. Parasitic and mutualistic associations between a mycorrhizal fungus and soybean: development of the host plant. Phytopathology, St. Paul, 72: 889-97, 1982a.

BETHLENFALVAY, G.J.; PACOVSKY, R.S.; BROWN, M.S. Parasitic and mutualistic associations between a mycorrhizal fungus and soybean: development of the endophyte.

Phytopathologx, St. Paul, 72: 894-7, 1982b.

BETHLENFALVAY, G.J.; PACOVSKY, R.S.; BROWN, M.S.; FULLER, G. Mycotrophic growth and mutualistic development of host plant and fungal endophite in an endonyoorrhizal symbiosis. Plant and Soil, The Hague, 68: 43-54, $1982 \mathrm{c}$. 
BIELESKI, R.L. Phosphate pools, phosphate transport, and phosphate availability. Annual Review Plant Physiology, Palo Alto, 24: 225-52, 1973.

BOLAN, N.S.: ROBSON, A.D.; BARROW, N.J. Plant and soil factors including mycorrhizal infection causing sigmoidal response of plants to applied phosphorus. Rlant and Soil, The Hague, 73: 187-202, 1983.

BOLAN, N.S.; ROBSON, A.D.; BARROW, N.J. Effects of vesicular-arbuscular mycorrhiza on the availability of iron phosphates to plants. Plant and Soil, The Hague, 99: $401-1 \cap .1987$.

BONFTTT, R. Ffeito de micorrizas vesiculares-arbusculares na nodulaça, crescimento e absorçăo de fósforo e nitrogênio em siratro. Revista brasileira de Ciência do solo, Caimptras, E: 189-92, 1984.

BONETTI, R.; MONTANHEIRO, M.N.S.; SAITO, S.M.T. The effects of phosphate and soil moisture on the nodulation and growth of Phaseolus vulgaris. Journal of Agricultural Science, Cambridge, 103: 95-102, 1984.

BONFANTE-FASOLO, P. \& GRIPPIOLO, R. Ultrastructural and cytoobomical changes in the wall of a vesiculararbuscular mycorrhizal fungus during symbiosis. Canadian Journal of Botany, Ottawa, 60: 2303-8, 1982.

BOWEN, G.D.; BEVEGE, D.I.; MOSSE, B. Phosphate physiology of vesicular-arbuscular mycorrhizas. In: SANDERS, F.E.; MOSSE, B.; TINKER,P.B., eds. Endomycorrhizas. London, Academic Press, 1975. p. 241-60.

BUHALDA, J.C.; ROSS, G.T.S.; STRIBLEY, D.P.; TINKER, P.B. The mathematical analysis of effects of phosphorus on the spread of vesicular-arbuscular mycorrhizal infection in root systems. New Ehytologist, Oxford, 92: 391-9, 1982.

BUWALDA, J.C.; STRIBLEY, D.P.; TINKER, P.B. Increased uptake of bromide and chloride by plants infected with vesicular-arbuscular mycorrhizas. Hew Phytologist, Oxford, 93: 217-25, 1983. 
CALlOW, J.A.; CAPPACIO, G.; PARISH, G.; TINKER, P.B. Detection and estimation of polyphosphate in vesiculararbuscular mycorrhizas. New Phytologist, Oxford, 80: 125$34,1978$.

CANAL, I.N. \& MIELNICZUK, J. Parâmetros de aborção de potássio em milho ( $Z$ ea mays L), afetados pela interação alumínio-cálcio. Ciência e Cultura, São Paulo, 35: $336-$ $40,1983$.

CAPPACIO, L.C.M. \& CALLOH, J.A. The enzymes of polyphosphate metabolism in vesicular-arbuscular mycorrhizas. New Phytologist, Oxford, 91: 81-91, 1982.

CARDoso, E.J.B.N. Efeito de micorriza vesiculo-arbuscular e fosfato de rocha na simbiose soja-Rhizobium. Revista. brasileira Ciência do Solo, Campinas, 9: 125-30, 1985.

CARDOSO, 2.J.B.N.... Eficiência de fungos micorrizicos vesículo-arbusculares em soja, com Rhizobium japonicum e fosfato de rocha, em função do tipo de solo. Revista brasileira Ciência do Solo, Campinas, 10: 17-23, 1986.

CARDOSO, E.J.B.N; ANTUNES, V.; SILVEIRA, A.P.D.; OLIVEIRA, H.H.A. Ericiência de fungos micorrizicos vesículoanbualaxes em porta enxertos de citros. Revista brasileira Ciência Solo, Campinas, 10: 25-30, 1986.

CARLING, D.E.; RIEHLE, H.G.; BROWN, M.F.; JOHNSON, S.R. Effects of a vesicular-arbuscular mycorrhizal fungus on nitrate reductase and nitrogenase activities in nodulating and non-nodulating soybeans. Bhytopathology, St. Paul, 68: 1590-6, 1978.

CARTWRIGHT, B. The effect of phosphate deficiency on the kinetics of phosphate absorption by sterile excised barley roots, and some factors affecting the ion uptake efficiency of roots. Soil Science Plant Analysis, 3: 31322,1972 . 
CASSMAN, K.G.; MUNNS, D.N.; BECK, D.P. Phosphorus nutrition of Rhirobium japonicum: strains differences in phosphate storage and utilization. Soil Science Society of American Journal, Madison, 45: 517-20, 1981.

CASTELLS, A.J. Absorça de fósforo e cálcio como oritério de seleção de genótipos de soja (Glycine max (L.) Merrill) quanto à tolerância ao alumínio. Viçosa, 1984. 62p. (MS Universidade Federal de Viçosa).

CASTELLS, A.J.; NEVES, J.C.L.; BARROS, N.F.; NOVAIS, R.F. Considerações referentes à determinação de parâmetros cinéticos de absorça de fósforo. Revista Ceres, Vicosa, 32: $85-91,1985$.

CLAASSEN, N. \& BARBER, S.A. A method for characterizing the relation between nutrient concentration and flux into roots of intaet plants. Plant Physiology, Lancaster, 54: $564-8,1974$.

CLAASSEN, N. \& BARBER, S.A. Simulation model for nutrient uptake from soil by growing plant root system. Agronomy journal, Madison, 68: 961-4, 1976.

CLARK, R.B. Plant genotype differences in the uptake, translocation, accumulation, and use of mineral elements reguired for plant growth. Plant and Soil, The Hague, 72: $175-96,1983$.

CLARKE, C. \& MOSSE, B. Plant growth responses to vesiculararbuscular mycorrhiza. XII- Field inoculation responses of barley at two soil P levels. New Phytologist, Oxford, 87: 695-703, 1981.

CLARKSON,D.T. Factors affecting mineral nutrient acquisition by plants. Annual Review Plant Physiology, Palo Alto, 36 : $77-115,1985$.

CLARKSON, D.T. \& HANSON, J.B. The mineral nutrition of higher plants. Annual Review Plant Ehysiology, Palo Alto, 31: $239-98,1980$. 
COBRA NETO, A.; ACCORSI, W.R.; MALAVOLTA, E. Estudos sobre a nutrição mineral do feijoeiro (Phaseolus vulgaris L.) var. Roxinho. Anais Escola Superior Agricultura "Luiz de Queiroz", Piracicaba, 28: 257-71, 1971.

COOPER, K.M. Growth responses to the formation of endotrophic mycorrhizas in Solanum, Leptospermum and New Zealands ferns. In: SANDERS, F.E.; MOSSE, B.; TINKER, P.B. ed. Endomycorrhizas. London, Academic press; 1975. p. 391-407.

COOPER, K.M. Physiology of VA mycorrhizal associations. In: POWELL, C.LI. \& BAGYARAJ, D.J. ed. VA Mycorrhiza. Boca Raton, CRC Press, 1984. p.155-86.

COOPER, K.M. \& LOSEL, D.M. Lipid physiology of vesiculararbuscular mycorrhiza. I-Composition of lipids in roots of onion, clover and ryegrass infected with Glomus mosseae. New Ehytologist, Oxford, 80: 143-51, 1978.

COOPER, K.M. \& TINKER, P.B. Translocation and transfer of nutrients in vesicular-arbuscular mycorrhizas. II- Uptake and translocation of phosphorus, zinc and sulphur. New Phytologist, Oxford, 81: 43-52, 1978.

CRESS, H.A.; THRONEBERRY, G.O.; LINDSEY, D.L. Kinetics of phosphorus absorption by mycorrhizal and nonmycorrhizal tomato roots. Plant Physiology, Lancaster, 64: 484-7, 1979 .

DAFT, M.J. \& EL-GIAHMI, A.A. Effect of Endogone mycorrhiza on plant growth. VII-Influence of infection on the growth and nodulation in french bean (Phaseolus vulgaris). New Bhytologist, Oxford, 73: 1139-47, 1974.

DAFT, M.J. \& EL-GIAHMI, A.A. Effects of Glomus infection on three legumes. In: SANDERS, F.E.; MOSSE, B.; TINKER, P.B., ed. Endomycorrhizas. London, Academic Press, 1975. p. $581-92$.

DAFT, M.J. \& EL-GIAHMI, A.A. Studies on nodulated and mycorrhizal peanuts. Annals of Applied Biology, London, 83: $273-6,1976$. 
DEMETRIO, J.L.; Ellis JR., R.; PAULSEN, G.M. Nodulation and nitrogen fixation by two soybean varieties as affected by phosphorus and zinc nutrition. Agronomy Journal, Madison, 64: $566-8,1972$.

DOBEREINER, J. Manganese toxicity effects on nodulation and nitrogen fixation of bean (Phaseolus vulgaris L.) in acid soil. Plant and Soil, The Hague, 24: 153-6, 1966.

DREW, M.C. \& SAKER, L.R. Uptake and long-distance transport of phozphate, potarsium and chloride in relation to internal ion concentrations in barley: evidence of ronallosteric regulation. Elenta, Berlim, 160: 500-7, 1984.

DREW, M.C.; SAKER, L.R.; BARBER, S.A.; JENKINS, W. Changes in the kinetics of phosphate and potassium absorption in nutrient-deficient barley roots measured by a solutiondepletion technique. Planta, Berlim, 160: 490-9, 1984.

EDWARDS, J.H. \& BARBER, S.A. Phosphorus uptake rate of goybean roots as influenced by plant age, root triming, and solution P concentration. Agronomy Journal, Madison, 68: $973-5,1976$.

EL-HASSANIN, A.S. \& LYND, J.Q. Soil fertility effects with antripartite symbiosis for growth, nodulation and nitrogenase activity of Vicia faba L. Journal Plant Nutrition, New York, 8: 491-504, 1985.

EPSTEIN, E. Nutricão mineral das plantas: Princípios e perspectivas. São Paulo, Ed. da Universidade de São Paulo, 1975. 344p.

EPSTEIN, E. \& HAGEN, C.E. A kinetic study of the absorption of alkali cations by barley roots. Plant Physiology, Lancaster, 27: 457-74, 1952.

FAQUIM, V. Cinética da absorça de fosfato, nutriça. mineral, crescimento e produção da soja sob influência de micorriza vesiculo-arbuscular (MVA). Piracicaba, 1988. 136p. (Doutorado - Escola Superior de Agricultura "Luiz de Queiroz"/USP). 
FEITOSA, C.T.; RONZELLI JR., P.; ALMEIDA, L.D. 'A.; VEIGA, A.A.; HIROCE, R.; JORGE, J.P.N. Adubaçăo NP para o feijoeiro (Phaseolus vulgaris L.) na presença e na ausência de calcário. Revista brasileira Ciência do Solo, Campinas, 4: 156-9, 1980.

FERREIRA, R.M. Efeito da inoculaçăo de fungo micorrizico VA no desenvolvimento do feijoeiro (Phaseolus vulgaris L.). Piracicaba, 1987. 80p. (Mestrado- Escola Superior de Agricultura "Luiz de Queiroz"/USP).

FRANCO, A.A. Micronutrient requirements of legume-Rhizobium symbiosis in the tropics. In: DOBEREINER, J.; BURRIS,R.H.; HOLLAENDER, A. ed. Limitations and potentials for Biological Nitrogen Eixation in the tropics. New York, Plenum Press, 1978. p. 161-71.

FRANCo, A.A., FRREIRA, J.C.; NEYRA, C.A. Seasonal patterns of nitrate reductase and nitrgenase activities in Phaseolus vulgaris L. Plant Physiology, Lancaster, 63: $421-4,1979$.

FURLANI, A.M.C. Variações em parâmetros de cinética de absorção de fósforo de três linhagens de arroz. Revista brasileira de Ciência do Solo, Campinas, 12: 77-80, 1988. FURLANI, A.M.C.; CLARK, R.B.; MARANVILLE, J.W.; ROSS, W.M. Sorghum genotype differences in phosphorus uptake rate and distribution in plant parts. Journal of Plant Nutxition, New York, Z: 1113-26, 1984.

GANRY, F.; DIEM, H.G.; DOMMERGUES, Y.R. Effect of inoculation with Glomus mosseae on nitrogen fixation by figld grown aoybeang. Elant and Soil. The Hague, 68: 3219, 1982.

GANRY, F.; DIEM, H.G.; WEY, J.; DOMMERGUES, Y.R. Inoculation with Glomus mosseae improves $\mathrm{N}_{2}$ fixation by field-grown soybeans. Biological Fertility Soils, 1: 15-23, 1985. 
GIANINAZZI-PEARSON, V.; FARDEAU, J.C.; ASIMI, S.; GIANINAZZI,

$S$. Source of additional phosphorus absorbed from soil by vesicular-arbuscular mycorrhizal soybeans. Physiologie Végétale, Paris, 19: $33-43,1981$.

GILMORE, A.E. The influence of endotrophic mycorrhizae on the growth of peach seedlings. Journal American Society Horticultura1 Science, Now York, 96: 35-8, 1971.

GODSE, D.B.; WANI, S.P.; PATIL, R.B.; BAGYARAJ, D.J. Response of cowpea (Vigna unguiculata (L.) Halp) to Rhizobiun - VA nycorrhiza dual inoculation. current Science, Bangalore, 47: 784-6, 1978.

GRAHAM, J.H. \& ROSAS, J.C. Phosphorus fertilization and symbiotic nitrogen fixation in common bean. Agronomy Journal, Madison, 71: 925-6, 1979.

GRAHAM, J.H. \& SYVERTSEN, J.P. Vesicular-arbuscular mycorrhizas increase chloride concentration in citrus seedlings. New Phytologist, oxford, 113: 29-36, 1989.

GRAHAM, J.H.; LINDERMAN, R.G.; MENGE, J.A. Development of external hyphae by different isolates of mycorrhizal Glomus spp. in relation to root colonization and Erowth of Troyer citrange. New Phytologist, Oxford, 91: 183-9, 1982 .

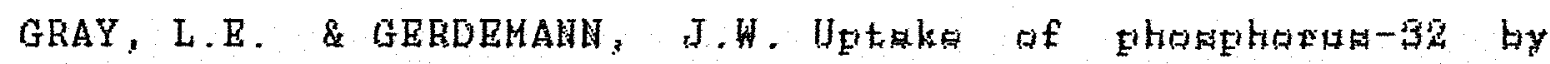
vesicular-arbuscular mycorrhizae. Plant and Soil, The Hague, 30: 415-22, 1969.

GRAY, L.E. \& GERDEMANN, J.W. Uptake of sulphur-35 by vesicular-arbuscular mycorrhizae. Plant and soil, The Hague, 39: 687-9, 1973.

HALE, K.A. \& SANDERS, F.E. Effects of benomyl on vesiculararbuscular mycorrhizal infection of red clover (Trifoliun pratense L.) and consequences for phosphorus inflow. Journal Plant Nutrition, New York, 5: 1355-67, 1982.

HALOS, P.M.; LUIS, E.M.; BORJA, M.S. Synergism between endomycorrhizas, Rhizobium japonioum CB 1809 and soybean (Glycine max (L.) Merr.). Philippine Agriculturist, Laguna, 65: $93-102,1982$. 
HARDIE, $K$. \& LEYTON, L. The influence of vesiculararbuscular mycorrhiza on growth and water relations of red clover. I- In phosphate deficient soil. New. Ehytologist, Oxford, 89: 599-608, 1981.

HARRIS, D.; PACOVSKY, R.S.; PAUL, E.A. Carbon economy of soybean - Rhizobium- Glomus associations. New Phytologist, Oxford, 101: 427-40, 1985.

HATTINGH, M.J.; GRAY, L.E.; GERDEMANN, J.H. Uptake and translocation of $32 \mathrm{P}-$ labelled phosphate to onion roots by endomycorrhizal fungi. Soil Science, Baltimore, 116: $383-7,1973$.

HAYMAN, D.S. Influence of soils and fertility on activity and survival of vesicular-arbuscular mycorrhizal fungi. Phytopathology, St. Paul, 72: 1119-25, 1982.

HAYMAN, D.S. The physiology of vesicular-arbuscular endomycorrhizal symbiosis. Canadian Journal of Botany, Ottawa, 61: 944-63, 1983.

HAYMAN, D.S. Mycorrhizae of nitrogen-fixing legumes. MIRCEN Journal of Applied Microbiology \& Biotecnology, Oxford, 2: $121-45,1986$.

HAMAN, D.S. \& MOSSE, B. Plant growth responses to vesicular-arbuscular mycorrhiza. III- Increased uptake of labille phosphorus from soil. New phytologist, Oxford, 71: $41-7,1972 \mathrm{a}$.

HAYMAN, D.S. \& MOSSE, B. The role of vesicular- arbuscular mycorrhiza in the removal of phosphorus from soil by plant roots. Revue d'Ecologie et de Biologie du Sol, Paris, 9: 463-70, 1972b.

HEPPER, C.M. Techniques for studying the infection of plants by vesicular-arbuscular mycorrhizal fungi under axenic conditions. New Phytologist, Oxford, 88: 641-7, 1981. 
HEPPER, C.M.; SEN, R.; MASKELL, C.S. Identification of vesicular-arbuscular mycorrhizal fungi in roots of leek (Allium porrun L.) and maize (Zea mays L.) on the basis of enzyme mobility during polyacrilimide gel electrophoresis. New Phytologist, Oxford, 102: 529-39, 1986.

HIROCE, R.; GALLO, J.R.; MIYASAKA, S. Análise foliar de feijoeiro. I-Nutrição nitrogenada e potássica. Bragantia, Campinas, 28: I-VIII, 1969. (Nota, 1).

HIROCE, R.; GALLO, J.R.; MASCARENHAS, H.A.A. Análise foliar em feijoeiro. II- Diagnose da nutricão fosfatada. Bragantia, Campinas, 29: VII-XII, 1970. (Nota, 2).

HO, I. Phytosterols in root systems of mycorrhizal and nonmycorrhizal Zea mays L. Lloydia, Cincinnatti, 40: 476-8, T977.

HOAGLAND, O.R. \& ARNON, O.I. The water-culture method for growing plants without soil. California, Agr. Exp. Stn., 1950. 32p. (Circular, 37)..

HUNGRIA, M. \& NEVES, M.C.P. Interação entre cultivares de

Phaseolus vulgaris e estirpes de Rhizobium na fixação e transporte do nitrogênio. Pesquisa Agropecuária Brasileira, Brasilia, 21: 127-40, 1986.

HUNGRIA, M.; NEVES, M.C.P.; VICTORIA, R.L. Assimilação do nitrogênio pelo feijoeiro. II- Absorção e translocação do $\mathrm{N}$ mineral e do $\mathrm{N} z$ fixado. Revista brasileira Ciência Solo, Campinas, 2: 201-9, 1985.

JACKSON, N.E.; MILLER, R.H.; FRANKLIN, R.E. The influence of vesicular-arbuscular mycorrhizae on uptake of $90 \mathrm{Sr}$ from soil by soybeans. Soil Biology \& Biochemistry, Oxford, 5: 205-12, 1973.

JAKOBSEN, I. Vesicular-arbuscular mycorrhiza in field-grown crops. III-Mycorrhizal infection and rates of $P$ inflow in pea plants. New Phytologist, Oxford, 104: 573-81, 1986.

JASPER, D.A.; ROBSON, A.D.; ABBOTT, L.K. Phosphorus and the formation of vesicular-arbuscular mycorrhizas. Soil Biology \& Biochemistry, Oxford, 11: 501-5, 1979. 
JAYACHANDRAN, K.; SCHWAB, A.P.; HETRICR, B.A.D. Mycorrhizal mediation of phosphorus availability: synthetic iron chelate effects on phosphorus solubilization. Soil Science Society American Journal, Madison, 53: 1701-6, 1989.

IAYACHAHDEAH, K.; HETRICK, B.A.D.; SCHHAB, A.F. Rolo of VA mycorrhizae in phosphorus acquisition from unavaible phosphorus sources. In: NORTH AMERICAM CONFERENCE ON MYCORRHIZAE, 8, Jackson, EUA, 1990. Abstracts, p.158.

JENSEN, P.\& PETTERSON, S. Allosteric regulation of potassium uptake in plant roots. Physiologia Rlantarum, Copenhagen, 42: $207-13,1978$.

JOHNSON, L.F. \& CURL, E.A. Methods for research on the ecology of soil-borne plant pathogens. Minneapolis, Butgess Publ. Co., 1972. p. 247.

JUNGK, A. \& BARBER, S.A. Phosphate uptake rate of corn root as related to the proportion of the root exposed to phosphate. Agronomy Journal, Madison, 66: 554-7, 1974. JUNGK, A. \& BARBER, S.A. Plant age and the phosphorus uptake characteristics of trimmed and untrimmed corn root spston: Plant and Soi1, The Hague, 42: 227-39, 1975.

KARUNARATNE, R.S.; BAKER,J.H.; BARKER, M. Phosphorus uptake by mycorrhizal and nonmycorrhizal roots of soybean. Journal Plant Nutrition, New York, 9: 1303-13, 1986.

KRISHNA, K.R.; SURESH, H.M.; SYAMSUNDER, J.; BAGYARAJ, D.J. Changes in the leaves on finger millet due to VA mycorrhizal infection. New Phytologist, Oxford, 87: 717$22,1981$.

KUCEY , R.M.N. \& JANZEN, H.H. Effects of VAM and reduced nutrient availability on growth and phosphorus and micronutrient uptake of wheat and field bean under greenhouse conditions. Plant and Soil, The Hague, 104: $71-8,1987$. 
KUCEY, R.M.N. \& PAUL, E.A. Biomass of mycorrhizal fungi associated with bean roots. Soil Biology \& Biochemistry, London, 14: 413-4, 1982 .

KUO, C.G. \& HUANG, R.S. Effect of vesicular-arbuscular mycorrhizae on the growth and yield of rice-stubble cultured soybeans. Plant and Soil., The Hague, 64: 325-30, 1982 .

LAMBAIS, M.R. Condições edáficas que afetam o micotrofismo de Stylosanthes guianensis (Aubl.)SW. Piracicaba, 1987. 102p. (MS- Escola Superior de Agricultura "Luiz de Queiroz"/USP).

LAMBAIS, M.R. \& CARDOSO, E.J.B.N. Avaliação da germinação de esporos de fungos micorrizicos vesículo-arbusculares e da colonização micorrizica de Stylosanthes guianensis em solo ảcido e distrófico. Revista brasileira Ciência Solo, Campinas, 12: 249-55, 1988 .

LAMBERT, D.H.; BAKER, D.E.; COLE, H. The role of mycorrhiza in the interactions of phosphorus with zinc, copper, and other elements. Soil Science Society American Journal, Madison, 43: $976-80,1979$.

LEE, N.B. Selectivity and kinetics of ion uptake by barley plants following nutrient deficiency. Annual Botany, London, 50: 429-49, 1982 .

LEFEBVRE, D.D. \& GLASS, A.D.M. Regulation of phosphate influx in barley roots: effects of phosphate deprivation and reduction of influx with provision of orthophosphate. Physiologia Plantarum, Copenhagen, 54: 199-206, 1982.

LEME ROCHA, G. As leguminosas e as pastagens tropicais. In: As leguminosas na Agxicultura Tropical. Ed. EMBRAPA, Centro-sul, 1971. p. 1-27.

LEHIS, D.G. \& QUIRK, J.P. Phosphate diffusion in soil and uptake by plants. III- $P$ movement and uptake by plants as indicated by aep autoradiography. Plant and SojI, The Hague, 26: 445-54, 1967 . 
LINDERMAN, R.G. Biocontrol and mediation of soil microbial activity. In: NORTH AMERICAN CONFERENCE ON MYCORRHIZA, 80, Jackson, EUA, 1990. Abstracts. p.186.

LINDGREN, D.T.; GABLEMEN, W.H.; GERLOFF, G.C. Variability of phosphorus uptake and translocation in Phaseolus vulgaris L. under phosphorus stress. Journal American Society. Horticultural Science, New York, 102: 674-7, 1977.

LOPES, E.S.; SIQUEIRA, J.0.; ZAMBOLIM, L. Caracterização das micorrizas vesicular-arbusculares (MVA) e seus efeitos no crescimento das plantas. Revista brasilejra Ciência do Solo, Campinas, $7: 1-19,1983$.

LU, S. \& MILLER, M.H. The role of VA mycorrhizae in the absorption of $\mathrm{P}$ and $\mathrm{Zn}_{\mathrm{n}}$ by maize in field and growth chamber experiments. Canadian Journal Soil Science, Ottawa, 69: 97-109, 1989.

MALAVOLTA, E.; VITTI, G.C.; DE OLIVEIRA, S.A. Avaliacãodo Estado Nutricional das Plantas. Piracicaba, Associaça Brasileira para pesquisa da Potassa e do Fosfato, 1989. $201 p$.

MALUF, A.M.; SILVEIRA, A.P.D.; MELO, I.S. Influência da calagem e da micorriza vesículo-arbuscular no desenvolvimento de cultivares de leucena tolerante e intolerante ao Alumínio. Revista brasileira Ciência do Sole, Campinas, 12: 17-23, 1988.

MANJUNATH, A.; MOHAN, R.; BAGYARAJ, D.J. Interaction between Beijerinckia mobilis, Aspergillus niger and Glonus fasciculatum and their effects on growth of onion. New Ehytologist, Oxford, 85: 723-7, 1981.

MANJUNATH, A.; BAGYARAJ, D.J.; GOPALA GOHADA, H.S. DuaI inoculation with VA mycorrhiza and Rhizobiun is. beneficial to Leucaena. Plant and Soil, The Hague, 78: $445-8,1984$. 
McGRAW, A.C.;GAMBLE, J.F.; SCHENCK, N.C. Vesiculararbuscular mycorrhizal uptake of Cesium-134 in two tropical pasture grass species. Bhytopathology, St. Paul, 69: 1038,1979 . (Abstr.).

McILVEEN, H.D.; SPOTTS, R.A.; DAVIS, D.D. The influence of soil zino on nodulation, mycorrhizae, and ozonesensitivity of Pinto bean. Phytopathology, St. Paul, 65: $645-7,1975$.

MCLACHLAN, K.D.; YAN-HUA, K.; MULLER, W.J. An assessment of the depletion technique for comparative measurement of phosphorus uptake in plants. Australian Journal Agriculture Research, Melbourne, 38: 263-77, 1987.

MELO, I.S.; SILVEIRA, A.P.D.; MALUF, A.M. Efeito do Aluminio e de Gloms leptotichum no desenvolvimento de cultivares de Leucaena Ieucocephala (Lam.) de Wit tolerante e intolerante ao Aluminio. Anais da Escola Superior de Agricultura "Luiz de Queiroz", Piracicaba, XLIY: 1365-80, 1987

MENGE, J.W.; STEIRLE, D.; BAGYARAJ, D.J.; JOHNSON, E.L.V.; LEONARD, R.T. Phosphorus concentrations in plants responsible for inhibition of mycorrhizal infection. New Phytologist, Oxford, 80: 575-8, 1978.

MENGEL, K. \& KIRKBY, E.A. Principles of plant nutrition. 40 ed. Berne, International Potash Institute, 1987. 687p.

MOJALLALI, H. \& WEED, S.B. Weathering of micas by mycorrhizal soybean plants. Soil Science Society American Journal, Madison, 42: $367-72,1978$.

MOSSE, B. Plant growth responses to vesicular-arbuscular mycorrhiza. IV- In soils given additional phosphate. New Rhytologist, Oxford, 72: 127-36, 1973.

MOSSE, B. Specificity of vesicular-arbuscular mycorrhizas. In: SANDERS, F.E.; MOSSE, - B.; TINKER, P.B., ed. Endomycorrhizas. London, Academic Press, 1975. p.469-84. 
MOSSE, B. Vesicular-arbuscular mycorrhize resegrch for tropical agriculture. Hawaii, Institute of Tropical Agriculture and Human Resources, 1981. 82p. (Research Bulletin, 194).

MOSSE, B.; HAYMAN, D.S.; ARNOLD, D.J. Plant growth responses to vesicular- arbuscular mycorrhiza. V- Phosphate uptake by three plant species from P-deficient soils labelled with 32P. New Phytologist, Oxford, 72: 809-15, 1973.

MURDOC, C.L.; JACKOBS, J.A.; GERDEMANN, J.W. Utilization of phosphorus sources of different availability by mycorrhizal and non-mycorrhizal maize. Plant and Soil, The Hague, 27: 329-34, 1967.

NAGY, S.; NORDBY, H.E.; NEMEC, S. Composition of lipids in roots of six citrus cultivars infected with the vesicular-arbuscular mycorrhizal fungus, Glomus nosseae. New Phytologist, Oxford, 85: 377-84, 1980.

NASCIMENTO FILHO, V.F. \& LOBAO, A.O . Deteccăo de $32 \mathrm{e}$ em amostras de origem animal e vegetal por efeito Cerenkov, cintilacão Iiquida e detector GM. Piracicaba, Centro de Energia Nuclear na Agricultura, 1977. 25p. (Boletim Cientifico, $\mathrm{BC}-048$ ).

NASSERY, H. Phosphate absorption by plants from habitats of different phosphate status. III- Phosphate fractions in the roots of intact plants. New Phytologist, Oxford, $70: 949-51,1971$.

NEMEC, S. \& MEREDITH, F.I. Amino acid content of leaves in mycorrhizal and non-mycorrhizal citrus root stocks. Annals of Botany, London, 47: 351-8, 1981.

NIELSEN, N.E. \& BARBER, S.A. Differences among genotypes of corn in the kinetics of $P$ uptake. Agronomy Journal, Madison, 70: 695-8, 1978.

NORDBY, H.E.; NEMEC, S,; NAGY, S. Fatty acids and sterols associated with citrus root mycorrhizae. Journal of Agriculture Food Chemistry, washington, 29: 396-401, 1981. 
OWUSU-BENNOAH, E. \& MOSSE, B. Plant growth responses to vesicular-arbuscular mycorrhiza. XI-Field inoculation responses in barley, lucerne and onion. New Phytologist, Oxford, 83: $671-9,1979$.

OWUSU-BENNOAH, E. \& WILD, A. Effects of vesicular-arbuscular mycorrhiza on the size of the labile pool of soil phosphate. Plant and Soil, The Hague, 54: 233-42, 1980.

PACOVSKY, R.S. Micronutrient uptake and distribution in mycorrhizal or phosphorus-fertilized soybeans. Elant and Soil. The Hague, 95: 379-88, 1986.

PACOVSKY, R.S. Carbohydrate, protein and amino acid status of Glycine-Glomus-Bradyrhizobiun symbioses. Rhysiologia Plantarum, Copenhagem, 75: 346-54, 1989.

PACOVSKY, R.S. \& FULLER, G. Development of two endomycorrhizal symbiosis on soybean and comparation with phosphorus fertilization. Plant and Soil, The Hague, 95: $361-77,1986$.

PACOVSKY, R.S. \& FULLER, G. Mineral and lipid composition of Glycine-Glomus-Bradyrhizobium symbioses. Physiologia Plantarum, Copenhagem, 72: 733-46, 1988.

PACOVSKY, R.S.; BETHLENFALVAY, G.J.; PAUL, E.A. Comparisons between P-fertilized and mycorrhizal plants. Crop Science, Madison, 26: 151-6, 1986a.

PACOVSKY, R.S.; FULLER, G.; STAFFORD, A.E.; PAUL, E.A. Nutrient and growth interactions in soybean colonized with Glomus fasciculatum and Rhizobium japonicum. Plant and Soil, The Hague, 92: 37-45, $1986 \mathrm{~b}$.

PACOVSKY, R.S.; PAUL, E.A.; BETHLENFALVAY, G.J. Response of mycorrhizal and P-fertilized soybeans to nodulation by Bradyrhizobium or amonium nitrate. Crop Science, Madison, 26: $145-50,1986 \mathrm{c}$. 
PAIRUNAN, A.; ROBSON, A.D.; ABBOTT, L.K. The effectiveness of vesicular-arbuscular mycorrhizas in increasing growth and phosphorus uptake of subterranean clover from phosphorus sources of different solubilities. New Rhytologist, Oxford, 84: 327-38, 1980.

PAULA, M.A. \& SIQUEIRA, J.O. Efeito de micorrizas vesiculararbusculares no crescimento, nodulação e acúmulo de nitrogênio pela soja. Pesquisa Agropecuária Brasileira, Brasilia, 22: 171-8, 1987.

PEREIRA, P.A.A \& BLISS, F.A. Nitrogen fixation and plant growth of common bean (Phaseolus vulgaris L.) at different levels of phosphorus availability. Rlant and Soil, The Hague, 104: 79-84, 1987.

PEREIRA, P.R.G.; SOARES, I.;BORGES, A.C.; NOVAIS, R.F.; RIBEIRO, A.C. Relação entre as concentraçöes de fósforo inorgânico nas folhas de soja e a colonização por fungos micorrizicos vesiculo-arbusculares. In: REUNIAO BRASILEIRA SOBRE MICORRIZAS, 2, São Paulo, 1987 . Resumos. P. 25 .

PHILLIPS, J.M. \& HAYMAN, D.S. Improved procedure for clearing roots and staining parasitic and vesiculararbuscular mycorrhizal fungi for rapid assessment of infection. Transactions British Mycological society, London, 55: 158-61, 1970.

POWELL, C.L1. Plant growth responses to vesiculararbuscular mycorrhiza. VIII- Uptake of $\mathrm{P}$ by onion and olover infected with different Fndogone epore types in 3ap labelled soils. New Phytologist, Oxford, 75: 563-6, 1975 .

RAIJ, B. van Avaliacão da fertilidade do solo. Piracicaba, . Instituto da Potassa e Fosfato, 1981. 142p.

RATNAYAKE, M.; LEONARD, R.T.; MENGE, J.A. Root exudation in relation to supply of phosphorus and possible relevance to mycorrhizal formation. Hew Phytologist, Oxford, 81: $543-52,1978$. 
RHODES, L.H. \& GERDEMANN, J.W. Phosphate uptake zones of mycorrhizal and non-mycorrhizal onions. New Phytologist, Oxford, 75: 555-61, ig75.

RHODES, L.H. \& GERDEMANN, J.W. Hyphal translocation and uptake of sulphur by vesicular-arbuscular mycorrhizae of onion. Soil Biology \& Biochemistry, Oxford, 70 : 355-60, 1978.

RÓSS, J.P. Effect of phosphorus fertilization on yield of mycorrhizal and non-mycorrhizal soybean. Bhytopathology, St. Paul, 61: 1400-3, 1971.

ROSS, J.P. \& HARPER, J.A. Effect of Endogone mycorrhiza on soybean yields. Phytopathology, st. Paul, 60: 1552-6, 1970 .

ROSS, J.P. \& GILLIAN, J.W. Effect of Endogone mycorrhiza on phosphorus uptake by soybean from inorganic phosphates. Soil Science Society of American Proceedings, Madison, 37: $237-39,1973$.

ROVIRA, A. Plant root exudates. The Botanical Revien, New York, 35: 17-34, 1969.

RUIZ, H.A. Estimativa dos parâmetros cinéticos $K_{m}$ e $V_{m a x}$ por uma aproximação gráfico-matemática. Revista Ceres, Vicosa, 32: $79-84,1985$.

RUSSEL, R.S. \& SANDERSON, J. Nutrient uptake by different parts of the intact roots of plants. Journal of Experimental Botany, Oxford, 18: 491-508, 1967.

SAFIR, G.R.; BOYER, J.S.; GERDEMANN, J.W. Nutrient status and mycorrhizal enhancement of water transport in soybean. Plant Physiology, Lancaster, 49: 700-3, 1972.

SAITO, S.M.T. \& RUSCHEL, A.P. Influência da calagem, adubaça fosfatada e micronutrientes na nodulação natural do feijoeiro (Phaseolus vulgaris L.). Anais Escola Superior Agricultura "Luiz de Queriroz", Piracicaba, 35 : 545-56, 1978. 
SAME, B.I.; ROBSON, A.D.; ABBOTT, L.K. Phosphorus, soluble carbohydrates and endomycorrhizal infection. Soil Biology. \& Biochemistry, Oxford, 15: 593-7, 1983.

SANDERS, F.E. \& TINKER, P.B. Mechanism of absorption of phosphate from soil by Endogone mycorrhizas. Nature, London, 233: 278-9, 1971.

SANDERS, F.E. \& TINKER, P.B. Phosphate flow into mycorrhizal roots. Pesticide Science, 4: 385-95, 1973.

SANDERS, F.E.; TINKER, P.B.; BLACK, R.L.B.; PALMERLY, S.M. The development of endomycorrhizal root systems. I. Spread of infection and growth promoting effects with four species of vesicular-arbuscular endophyte. New Bhytologist, Oxford, 78: 257-68, 1977.

SARRUGE, J.R. \& HAAG, H.P. Análises químicas em plantas. Piracicaba, Depto de Química, ESALQ/ USP, 1974. (Mimeografado).

SCHENK, M.K. \& BARBER, S.A. Phosphate uptake by corn as affected by soil characteristics and root morphology. Sail Science American Journal, Madison, 43: 880-3, 1979. SCHOENEBERGER, M.M.; VOLK, R.J.; DAVEY, C.B. Selection of preference plants for estimating $\mathrm{Nz}$ fixation in mycorrhizal leguminous plants. Soil Science Society America Journal, Madison, 53: 1425-9, 1989a.

SCHOENEBERGER, M.M.; VOLK, R.J.; DAVEY, C.B. Factors influencing early performance of leguminous plants in forest soils. Soil Science Society America Journal, Madison, 53: 1429-34, 1989b.

SELVARAJ, T. \& SUBRAMANIAN, G. Phenols and lipids in mycorrhizal and non-mycorrhizal roots of Sesamum indicum. Current Science, Bangalore, 59: 471-3, 1990.

SIDDIQI, M.Y. \& GLASS, A.D.M. Utilization index: a modified approach to the estimation and camparison of nutrient utilization efficiency in plants. Journal of Plant Nutrition, New York, 4: 289-312, 1981. 
SIEVERDING, E. Influence of soil water regimes on VA mycorrhiza. I- Effect on plant growth, water utilization and development of mycorrhiza. Journal Agronomy and Crop Science, 150: 400-11, 1981.

SILVA, F.L.I.M. \& MAGALHAES, J.R. Análise de sensibilidade dos parâmetros utilizados na simulação de absorção de fosforo pelo tamatejro, con o modelo matemático de Cushman-Parber. Revista brasileira Ciencia do Salo, Campinas, 13: $315-20,1989$.

SILVEIRA, A.P.D. \& CARDOSO, E.J.B.N. Efeito do fósforo e da micorriza vesiculo-arbuscular na simbiose Rhizobiumfeijoeiro. Revista brasileira Ciência do Solo, Campinas, 11: $31-6,1987 \mathrm{a}$.

SILVEIRA, A.P.D. \& CARDOSO, E.J.B.N. Influência do tipo de solo e do fungo micorrízico vesículo-arbuscular no desenvolvimento de três cultivares de feijăo. Revista brasileira CiBnoia do Solo, Campinas, 11: $37-43,1987 \mathrm{~b}$.

SILVEIRA, A.P.D. \& CARDoso, E.J.B.N. Efeito de MVA e rizóbio nos parâmetros cinéticos de absorçăo radicular de 32P por soja. In: SIMPOSIO LATINOAMERICANO DE MICORRIZAS, I, Havana, Cuba, 1990. Resumos. p.13.

SILVEIRA, A.P.D. \& CARDOSO, E.J.B.N. Absorção de P mediada por micorriza VA em soja tolerante e intolerante ao Al. In: REUNIAO INTERNACIONAL SOBRE BIOLOGIA DE PLANTAS DO CERRADO e CONGRESSO BRASILEIRO DE BOTANICA, I, Campinas, SP, 1990. Resumos. p. 149.

SIQUEIRA, J.O. \& PAULA, M.A. Efeito de micorrizas vesiculararbusculares na nutricão e aproveitamento de fósforo pela soja em solo-sob cerrado. Revista Brasilejra Ciência do Solo, Campinas, 10: 97-102, 1986.

SIQUEIRA, J.0.; HUBBELL, D.H.; VALLE, R.R. Effects of phosphorus on formation of the vesicular-arbuscular mycorrhizal symbiosis. Pesquisa Agropecuária Brasileira, Brasilia, 19: 1465-74, 1984. 
SMITH, S.E. Inflow of phosphate into mycorrhizal and nonmycorrhizal plants of Trifolium subterraneum at different levels of soil phosphate. New Phytologist, Oxford, 90: 293-303, 1982 .

SMITH, S.E. Phosphorus fluxes in vesicular-arbuscular mycorrhizal plants: relationships with infection and enviromental variables. In: NORTH AMERICAN CONEERENCE ON MYCORRHIZAE, 80, Jackson, EUA, 1990. Abstracts. p.266.

SMITH, S.E. \& DAFT, M.J. Interactions between growth, phosphate content and $\mathrm{N}_{2}$ fixation in mycorrhizal and nonmycorrhizal Medicago sativa. Australian Journal Plant Rhysiology, Melbourne, 4: 403-13, 1977.

SMITH, S.E. \& GIANINAZZI-PEARSON, V. Physiological interactions between symbionts in vesicular-arbuscular mycorrhizal plants. Annual Review Plant Rhysiology Plant Molecular Biology, Palo Alto, 39: 221-44, 1988.

SMITH, S.E.; NICHOLAS, D.J.D.; SMITH, F.A. Effect of early mycorrhizal infection on nodulation and nitrogen fixation in Trifolium subterraneum. Australian Journal of Plant Rhysiology, Melbourne, 6: 305-11, 1979.

SMITH, S.E.; SMITH, F.A.; NICHOLAS, D.J.D. Effects of endomycorrhizal infection on phosphate and cation uptake by Trifolium subterraneum. Plant and Soil, The Hague, 63: $57-64,1981$.

SMITH, S.E.; ST JOHN, B.J.; SMITH, F.A.; BROMLEY, J.L. Effect of mycorrhizal infection on plant growth nitrogen and phosphorus nutrition of glasshouse-grown Allium cepa L. New Phytologist, Oxford, 103: 359-73, 1986.

SNELLGROVE, R.C.; SPLITSTOESSER, H.E.; STRIBLEY, D.B.; TINRER, P.B. The distribution of carbon and the demand of the fungal symbiont in leek plants with vesiculararbuscular mycorrhizas. New Phytologist, Oxford, 92: 7587,1982 . 
SPARLING, G.P. \& TINKER, P.B. Mycorrhizal infection in Pennine grassland. III- Effects of mycorrhizal infection on the growth of white clover. Journal Applied Ecology, London, 15: 943-50, 1978.

STRIBLEY, D.P.; TINKER, P.B.; RAYNER, J.H. Relation of internal phosphorus concentration and plant weight in plants infected by vesicular-arbuscular mycorrhizas. Hen Phytologist, Oxford, 86: 261-6, 1980.

SHAMINATHAN, K. \& VERMA, B.C. Responses of three crop species to vesicular-arbuscular mycorrhizal infection on zinc deficient Indian soils. New Phytologist, Oxford, 82: $481-7,1979$.

THOMPSON, J.P. Soil sterilization methods to show VAmycorrhizae aid $P$ and $Z n$ nutrition of wheat in vertisols. Soil Biology \& Biochemistry, oxford, 22: 229-40, 1990.

TIMMER, L.H. \& LEYDEN, R.F. Stunting of citrus seedlings in fumigated soils in Texas and its correction by phosphorus fertilization and inoculation with mycorrhizal fungi. Journal American Society Horticultural Science, New York, 103: 533-7, 1978.

TINKER, P.B. The soil chemistry of phosphorus and mycorrhizal effects on plant growth. In: SANDERS, F.E.; MOSSE, B.; TINKER, P.B., ed. Endomycorrhizas. London, Academic Press, 1975. p. 353-71.

TINKER, P.B. Effects of vesicular-arbuscular mycorrhizas on plant nutrition and plant growth. Ehysiologie Végétale, Paris, 16: 743-51, 1978 .

VALE, F.R. do; NOVAIS, R.F. de; BARROS, N.F. de; MILAGRES,B.G. Absorção de nitrato e amônio por raízes intactas de milho pré-tratadas com Aluminio. Revista brasileira Ciência do Solo, Campinas, 8: 215-8, $1984 a$. 
VALE, F.R. do; NOVAIS, R.F.; SANT'ANNA, R.; BARROS, N.F. Absorção e translocação de fosfato em milho suprido com nitrato ou amônio e pré-tratado com Aluminio. Revista Brasileira Ciência de Solo, Campinas, 8: 219-22, 1984 b.

VEJSADOVA, H.; HRSELOVA, H ; PRIKRYL, Z ; VANCURA, V. Effect of different phosphorus and nitrogen levels on development of VA mycorrhizg, rhizobial gotivity and soybean growth. Agriculture, Ecosystems and Enviroment, Praga, 29: 429-34, 1989.

VINCENT, J.M. A manual for the practical study of root= nodule bacteria. Oxford, Blackwell scientific Publ., 1970. 164p. (IBP Handbook no 15).

VILELA, L. \& ANGHINONI, I. Morfologia do sistema radicular e oinetica da absorøão de fósforo em cultivares de soja afetados pela interacão alumínio-fósforo. Revista brasileira Ciência do Solo, Campinas, 8: 91-6, 1984.

ZHANG, G. \& TAYLOR, G.J. Kinetics of Aluminum uptake by excised roots of Aluminum-tolerant and Aluminum-sensitive cultivars of Triticum aestivum L. Plant Physiology, Lancaster, 91: 1094-9, 1989.

WARNCKE, D.D. \& BARBER, S.A. Root development and nutrient uptake by corn grown in solution culture. Agronomy Journal, Madison, 66: $514-6,1974$.

WILCOX, G.E. \& FAGERIA, N.K. Deficiências nutricionais do feijao, sua identificacão e correcão. Goiânia, EMBRAPACNPAE, 1976. 22p. (Boletim Técnico, 5).

WOOLHOUSE, H.W. Membrane structure and transport problems considered in relations to phosphorus and carbohidrate movements and the regulations of endotrophic mycorrhizal associations. In: SANDERS, F.E.; MOSSE, B.; TINKER, P.B., ed. Endomycorrhizas, London, Academic Press, 1975. p. $209-40$. 
8 - APENNDICE 
Apêndice 1-Equaços de regressão para ajuste dos dados de exaustáo de $P$ (Q- quantidade de $P$ na solucão, umol) em função do tempo de absorção ( $t$, hora), para obtencabo dos parketros eineticos da absorcăo de $P$, segundo a aproximação gráficomatemática proposta por RUIZ (1985). (Experimento I).

\begin{tabular}{|c|c|c|}
\hline TRATAMENTOS 1 & EQUAÇÕES DE AJUSTE & $\mathrm{R}^{2} 2$, \\
\hline $\mathrm{T}-\mathrm{P}_{1}$ & $\begin{array}{l}Q=27.06-10.72 t \\
Q=48.82 . t-2.89\end{array}$ & $\begin{array}{l}0.999 * * \\
0.995 * *\end{array}$ \\
\hline $\mathrm{T}-\mathrm{Pz}$ & $\begin{array}{l}Q=26.31-11.03 t \\
Q=34.57-t-2.23\end{array}$ & $\begin{array}{l}0.994 * * \\
0.992 * *\end{array}$ \\
\hline $\mathrm{GE}-\mathrm{P}_{1}$ & $\begin{array}{l}Q=26.50-13.38 t \\
Q=22.02, t-2.04\end{array}$ & $\begin{array}{l}0.996^{* *} \\
0.991^{* *}\end{array}$ \\
\hline $\mathrm{GE}-\mathrm{P}_{2}$ & $\begin{array}{l}Q=26.69-8.54 t \\
Q=32.31, t-1.56\end{array}$ & $\begin{array}{l}0.997 * * \\
0.994 * *\end{array}$ \\
\hline $\mathrm{SH}-\mathrm{P}_{1}$ & $\begin{array}{l}Q=25.96-14.61 t \\
Q=15.92, t-2.71\end{array}$ & $\begin{array}{l}0.991 * * \\
0.998 * *\end{array}$ \\
\hline $\mathrm{SH}-\mathrm{P}_{2}$ & $\begin{array}{l}Q=26.09-11.28 t \\
Q=30.83 \cdot t-2.11\end{array}$ & $\begin{array}{l}0.990 * * \\
0.990 * *\end{array}$ \\
\hline
\end{tabular}

1/Tratamentos: T-Testemunha; GE- Glomus etunicatum; $\mathrm{SH}-$ Scutellospora heterogama; $\mathrm{P}_{1}-0.3 \mathrm{ppm} ; \mathrm{P}_{2}-3.0 \mathrm{ppm}$. $2 / * *-$ Significativo a $1 \%$. 
Apêndice 2-Equaçoses de regressão para ajuste dos dados de exaustão de $P(Q-$ quantidade de $P$ na solucão, umol) en funcão do tempo de absorcão ( $t$, hora) para obtencão dos parametros einéticos da absorça de $P$, empregando a aproximacăo gráficomatematica de RUIZ (1985). (Experimento II).

\section{CARIOCA}

$\mathrm{T}-\mathrm{P}_{1}$

$\mathrm{T}-\mathrm{P}_{2}$

GE

$\mathrm{SH}$

NEGRO ARGEL

$\mathrm{T}-\mathrm{P}_{1}$

$\mathrm{T}-\mathrm{P}_{2}$

GE

SH

$$
\begin{array}{ll}
Q=25.68-3.85 t & 0.998^{* *} \\
Q=62.30 \cdot t^{-1.30} & 0.988^{* *} \\
Q=24.44-4.10 t & 0.994^{* *} \\
Q=56.97 \cdot t^{-1.34} & 0.993^{*} \\
Q=26.26-6.31 t & 0.994^{* *} \\
Q=139.61 \cdot t-2.47 & 0.983^{* *} \\
Q=23.33-3.67 t & 0.990^{* *} \\
Q=214.75 \cdot t-2.19 & 0.994^{*}
\end{array}
$$

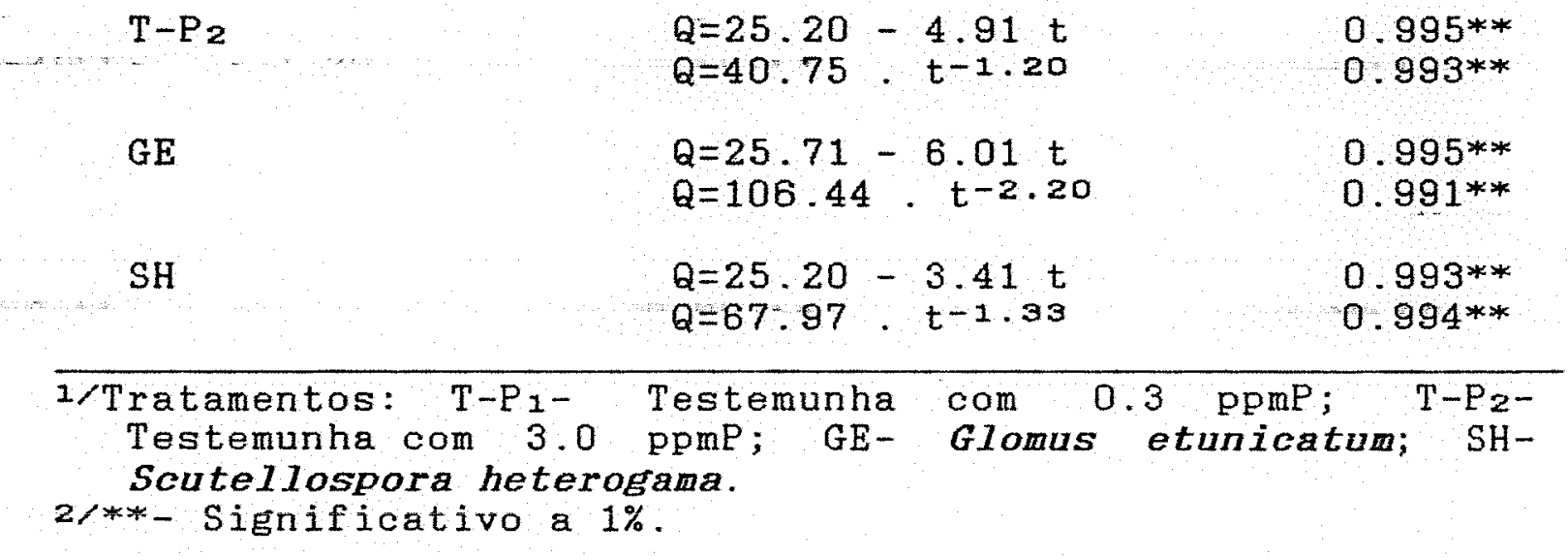

$0.994 * *$

$0.989 * *$

$Q=25.97-3.81 t$

$Q=43.86 * t^{-0.91}$

$0.995 * *$

$0.995 * *$

$0.993 * *$

$Q=25.20-3.41 . t$ a 
Apêndice 3 -Valores de $F^{1 /}$ da análise da variância $\theta$ coeficiente de variaça das variáveis analisadas no Experimento II : efeito de fungos micorrizicos em duas cultivares de feijáo.

\section{VARIÁVEIS}

$+$

\section{CAUSAS DE YARIACĀO FUNGO CULT . * FUNGO}

$\mathrm{CV}$

\begin{tabular}{|c|c|c|c|c|}
\hline GL & 1 & 3 & 3 & $\%$ \\
\hline EMSPA & $3.97 \mathrm{~ns}$ & $107.99 * *$ & $5.41 * *$ & 10.05 \\
\hline PMSNOD & $6.93^{*}$ & $408.76^{* *}$ & $4.84 * *$ & 13.44 \\
\hline INFECCAO : & $1.05 \mathrm{ma}$ & $1042.65 * *$ & $0.35 \mathrm{ng}$ & 12.69 \\
\hline$N \%$ & $4.46^{*}$ & $26.49 * *$ & $5.76 * *$ & 4.51 \\
\hline$P \%$ & $7.33^{* *}$ & $10.19 * *$ & $0.24 \mathrm{~ns}$ & 7.22 \\
\hline R \% & $24.42 * *$ & $23.12 * *$ & $1.76 \mathrm{mg}$ & 5.56 \\
\hline $\mathrm{Ca} \%$ & $0.34 \mathrm{ng}$ & $23.19 * *$ & $9.54 * *$ & 5.70 \\
\hline $\mathrm{Mg} \%$ & $2.68 \mathrm{~ns}$ & $20.48 * *$ & $5.44 * *$ & 5.20 \\
\hline $\mathbb{N}$ total & $0.08 \mathrm{ng}$ & $31.59 * *$ & $5.01^{* *}$ & 11.59 \\
\hline P total & $1.09^{n g}$ & $92.66^{* *}$ & $0.64^{\mathrm{ng}}$ & 14.57 \\
\hline $\mathrm{K}$ total & $10.04^{* *}$ & $20.08 * *$ & $0.20^{n g}$ & 13.75 \\
\hline Ca total & $0.04 \mathrm{~ns}$ & $22.94 * *$ & $3.19 *$ & 12.72 \\
\hline Mg total & $0.19 \mathrm{ng}$ & $105.30 * *$ & $0.36 \mathrm{ng}$ & 12.64 \\
\hline $\mathrm{Fe} \mathrm{ppm}$ & $6.03^{*}$ & $6.93^{* *}$ & $17.52 * *$ & 38.05 \\
\hline $\mathrm{Zn}$ ppm & $8.19 * *$ & $2.40^{n g}$ & $6.17 * *$ & 19.13 \\
\hline $\mathrm{Cu} \mathrm{ppm}$ & $0.09 n a$ & $32.72 * *$ & $5.24 * *$ & 18.15 \\
\hline $\mathrm{Mn} \mathrm{ppm}$ & $1.98^{n g}$ & $57.26 * *$ & $15.38 * *$ & 14.82 \\
\hline Fe total & $5.74 * *$ & $13.15^{* *}$ & $16.32 * *$ & 35.25 \\
\hline Zn total & $13.27 * *$ & $25.42 * *$ & $2.54 *$ & 20.01 \\
\hline Cu total & $0.11 \mathrm{ng}$ & $81.50 * *$ & $4.42 * *$ & 18.37 \\
\hline Mn total & $0.05 \mathrm{ng}$ & $121.96 * *$ & $17.52 * *$ & 16.52 \\
\hline
\end{tabular}


Apêndice 4-Equaçoes de regressão para ajuste dos dados de exaustăo de $P(Q=$ quantidade de $P$ na solucão, umol) em funcăo do tempo de absorgão ( $t$, hora) para obtencão dos parametros cineticos de absorgão de $P$, segundo a aproximagão gráficomatemática de RUIZ (1985). (Experimento.III).

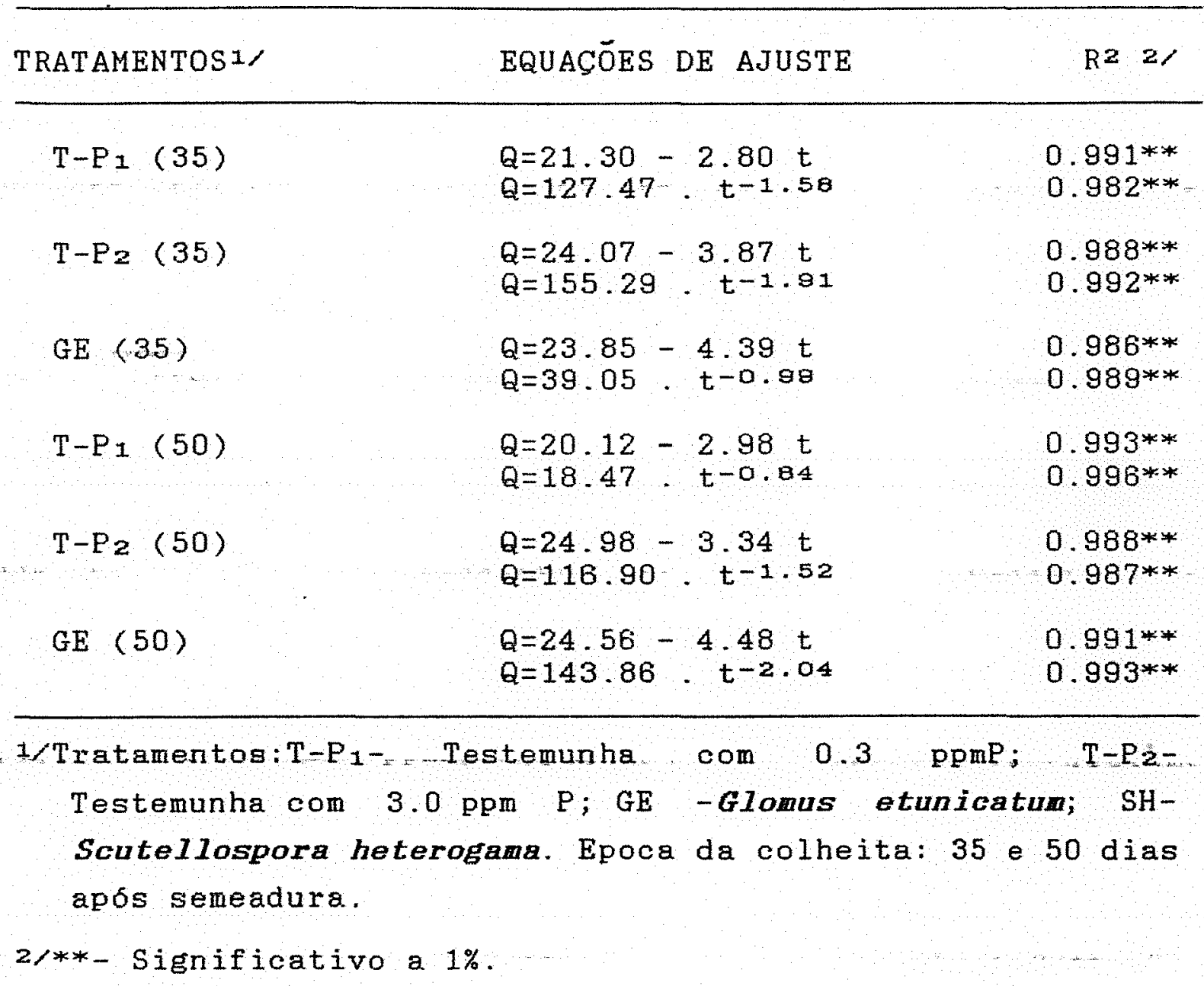


Apêndice 5-Valores de $F^{1 /}$ da análise da variância e coeficiente de variação das variáveis analisadas no Experimento III:efeito da micorriza estabelecida no feijoeiro, em duas épocas do ciclo da planta.

\begin{tabular}{|c|c|c|c|c|}
\hline \multirow[t]{2}{*}{ VARIÁVEIS } & \multicolumn{3}{|c|}{ CAUSAS DE YARIAC̆CAO } & \multirow[t]{2}{*}{$\mathrm{CV}$} \\
\hline & EPOCA & FUNGO & EPOCA*FUNGO & \\
\hline GL & 1 & 2 & 2 & $\%$ \\
\hline PMSPA & $126.76^{* *}$ & $21.78 * *$ & $9.74 * *$ & 19.76 \\
\hline INFECCĂO \% & $84.79 * *$ & $849.61 * *$ & $84.79 * *$ & 16.81 \\
\hline $\mathrm{N} \%$ & $105.15^{* *}$ & $2.72^{\mathrm{ns}}$ & $0.86 n \pi$ & 4.60 \\
\hline P $\%$ & $4.17 \mathrm{~ns}$ & $22.79 * *$ & $14.67 * *$ & 5.83 \\
\hline $\mathrm{K} \%$ & $7.68^{*}$ & $0.93 n s$ & $5.45 *$ & 5.82 \\
\hline $\mathrm{Ca} \%$ & $13.94 * *$ & $1.40 \mathrm{ne}$ & $0.18 \mathrm{n} s$ & 7.67 \\
\hline ME \% & $20.28 * *$ & $3.31 \mathrm{~ns}$ & $10.25 * *$ & 10.63 \\
\hline $\mathrm{N}$ total & $64.82 * *$ & $22.27 * *$ & $7.87 * *$ & 17.73 \\
\hline P total & $102.54^{* *}$ & $33.01 * *$ & $11.94 * *$ & 22.61 \\
\hline $\mathrm{K}$ total & $149.77 * *$ & $29.82 * *$ & $4.96 *$ & 15.24 \\
\hline Ca total & $116.42^{* *}$ & $22.85 * *$ & $11.01 * *$ & 24.70 \\
\hline ME total & $130.08^{* *}$ & $26.04 * *$ & $24.77 * *$ & 28.57 \\
\hline $\mathrm{Zn} p \mathrm{ppm}$ & $3.14 \mathrm{~ns}$ & $4.06^{*}$ & $6.78 *$ & 11.89 \\
\hline $\mathrm{Cu}$ ppm & $16.45 * *$ & $33.07 * *$ & $14.52 * *$ & 16.48 \\
\hline $\mathrm{Zn}$ total & $90.81 * *$ & $7.37 * *$ & $2.53 n a$ & 24.67 \\
\hline Cu total & $48.46^{* *}$ & $20.20 * *$ & $2.53 n=$ & 23.27 \\
\hline
\end{tabular}

1/ng,* e **: Nao significativo e significativo a $5 \%$ e $1 \%$, respectivamente. 